UNIVERSIDADE DE SÃO PAULO

INSTITUTO DE GEOCIENCIAS

\title{
CARACTERIZAÇÃO MORFOLÓGICA, QUÍMICA E MINERALÓGICA DE MICROAGREGADOS DE UM LATOSSOLO ROXO DE IRACEMÁPOLIS, SP E DE PELOTAS PRODUZIDAS POR CUPINS
}

Celso Aluísio Graminha

Orientador: Prof. Dr. Adolpho José Melfi

DISSERTAÇÃO DE MESTRADO

Programa de Pós-Graduação em Geoquímica e Geotectônica 


\section{UNIVERSIDADE DE SÃO PAULO \\ INSTITUTO DE GEOCIENNCIAS}

\section{CARACTERIZAÇÃO MORFOLÓGICA, QUÍMICA E MINERALÓGICA DE MICROAGREGADOS DE UM LATOSSOLO ROXO DE IR̃ACEMÁPOLIS, SP E DE PELOTAS PRODUZIDAS POR CUPINS}

\section{CELSO ALUÍSIO GRAMINHA}

Orientador: Prof. Dr. Adolpho José Melfi

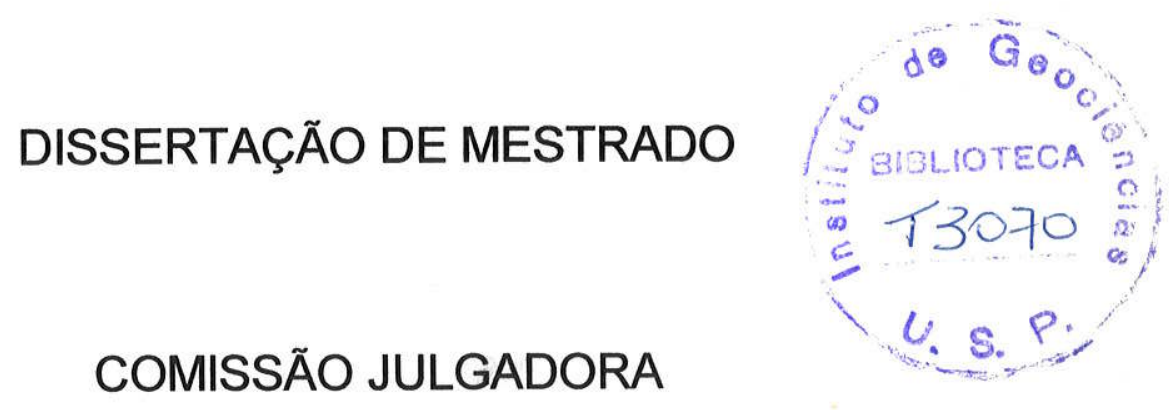

Nome

Presidente: Prof. Dr. Adolpho José Melfi

Examinadores: Dr. Mathieu Benoit Jean Lamotte

Prof. Dr. Miguel Cooper

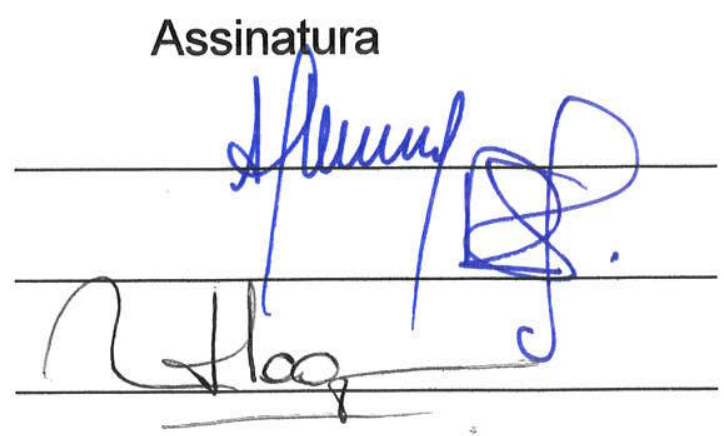

SÃO PAULO

2001 
UNIVERSIDADE DE SÃO PAULO

INSTITUTO DE GEOCIÊNCIAS

CARACTERIZAÇÃO MORFOLÓGICA, QUIIMICA E MINERALÓGICA DE MICROAGREGADOS DE UM LATOSSOLO ROXO DE IRACEMÁPOLIS,SP E DE PELOTAS PRODUZIDAS POR CUPINS

Celso Aluísio Graminha

Orientador: Prof. Dr. ADOLPHO JOSÉ MELFI

DISSERTAÇÃO DE MESTRADO

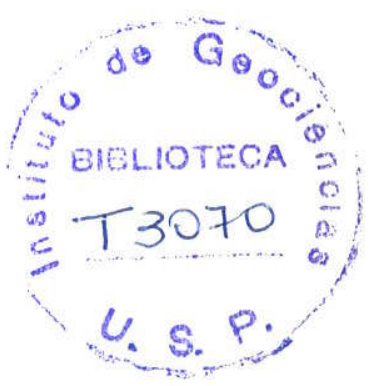

Programa de Pós-Graduação em Geoquímica e Geotectônica, Área de Concentração em Geoquímica de Processos Supérgenos

SÃO PAULO - 2000

DEDALUS - Acervo - IGC

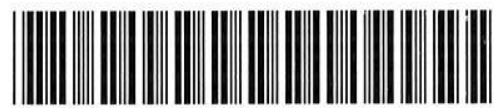

30900006297 
"Talvez não haja lugar no mundo onde as formigas e os térmitas tenham tanta importância geológica como no Brasil". (Branner, 1915)

$$
\begin{array}{r}
\text { " No chão duro e estéril, sarjado } \\
\text { pelos sulcos das estradas antigas, } \\
\text { cresceram os calombos escuros dos } \\
\text { cupinzeiros. }
\end{array}
$$

Há uma doença má Que há muitos anos atacou a terra desses campos inutilizando-os com os cupins que furam o solo, deixando-os esburacados que nem peneira"

Antonio Constantino (Este é o canto da minha terra...) In: Lenko \& Papavero, 1996

"Para que nos interessem o quanto é necessário essas vidas que não estão em nossa escala, suponhamos que se trata da história de uma raça pré-humana que tivesse existido na Terra milhares ou milhões de anos antes de nós. Nada nos indica que não tenham existido, como tampouco nos afirma nenhum sintoma que não haja de surgir uma raça pós-humana milhares ou milhões de anos depois que desapareça a nossa. Na infinidade do tempo o passado e o porvir são intercambiáveis".

Maurice Maeterlinck 


\section{AGRADECIMENTOS}

Gostaria de expressar minha gratidão a todos que participaram nas mais variadas formas para a concretização deste trabalho, destacando que o espírito da coletividade deve estar sempre presente na formação científica.

Ao Prof. Adolpho José Melfi pela orientação científica e ensinamentos ao longo do trabalho.

Ao pesquisador Dr. Vincent Eschenbrenner, do "Institut de Recherche pour le Developpment" (IRD, ex-Orstom) pelo apoio.

Ao pesquisador Matieu Lamotte do "Institut de Recherche pour le Developpment" (IRD, ex-Orstom) pelo apoio e incentivo.

Ao Prof. Dr. Adilson Carvalho (ex-diretor) e Prof. Dr. Wilson Teixeira, diretor em curso do Instituto de Geociências, por propiciarem as condições para o desenvolvimento dos cursos de mestrado e de graduação.

À Prof. Dra. Eliana Marques Cancello, do Museu de Zoologia da USP, pelas sugestões nos trabalhos com cupins.

À Fundação de Amparo à pesquisa do Estado de São Paulo-FAPESP pela bolsa de estudos e apoio financeiro concedidos à pesquisa.

Ao NUPEGEL (Núcleo de Pesquisas em Geoquímica e Geofísica da Litosfera) pela infra-estrutura disponibilizada durante todo o desenvolvimento do trabalho.

À Prof. Dra. Célia Regina Montes Lauar pelo apoio.

A Dra. Vânia Rosolen pelo incentivo ao longo do trabalho.

Aos pós-graduandos e amigos Àlvaro L. Mafra, Márcia T. Soares, Liliane Ibrahim, Célia Surita, Adriel F. da Fonseca, (NUPEGEL/ESALQ); André L. Bonacim e Silva , Alexandre M.F. Sales e Claudio Pires Florencio (IGc-USP).

Aos funcionários do NUPEGEL pela presteza e profissionalismo prestados: secretária Sra. Clotilde M. Batochio, Engenheiro Ney Sampaio, pelo auxílio nas análises de difração de raios $\mathrm{x}$ e microscopia eletrônica de varredura; técnicos Paulo Sebastião, Filipe Grizotto. 
As Sras. Magali e Ana Paula secretária da Seção de pós Graduação do Instituto de Geociências pela amizade e presteza nos assuntos acadêmicos.

As Sras. Rosana, Rosangela e Glória, secretárias da vice reitoria pela ajuda prestada.

Ao Departamento de Solos e Nutrição de Plantas pela disponibilidade no uso da infra-estrutura disponível (microscopia, laminação).

Ao Laboratório de Biogeoquímica do Solo, do Centro de Energia Nuclear na Agricultura CENA/ESALQ, pelas análises de Carbono e Nitrogênio totais, sob responsabilidade dos Profs. Carlos Clemente Cerri e Marisa de Cassia Piccolo.

Ao Laboratório de Escola Politécnica pelas análises de granulometria a raios laser, sob responsabilidade do Prof. Dr. Antonio Carlos V. Coelho.

Aos companheiros Piracicabanos Tiago Altafini, Rodrigo Simom e Marcelo Brandão.

A todos os familiares pelo apoio em todos os momentos.

Especialmente à minha esposa Márcia e meu filho Pedro por tudo que representam para mim. 


\section{SUMÁRIO}

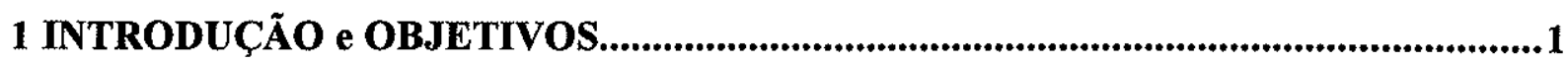

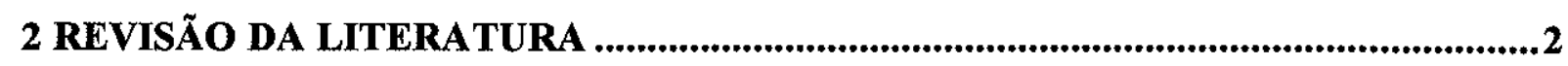

2.1 Considerações principais sobre a gênese e caracterização do Latossolo Roxo ………........2

2.2 Síntese sobre processos de microagregação de partículas ................................................

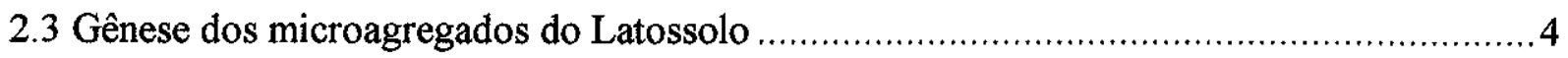

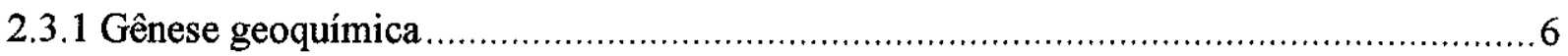

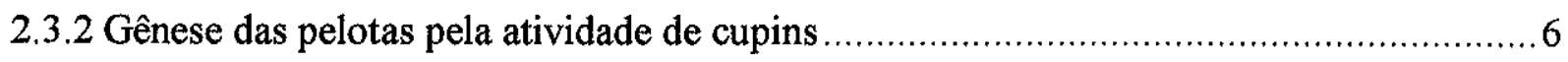

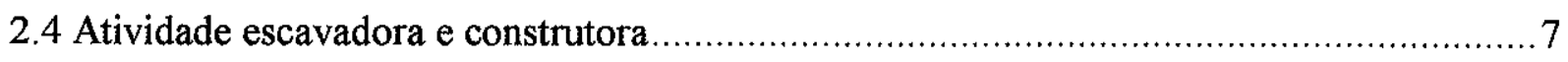

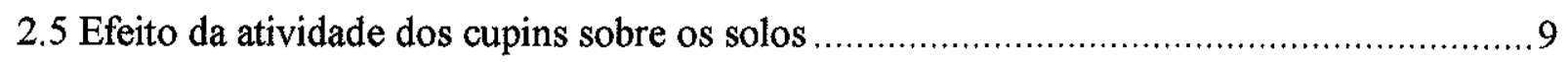

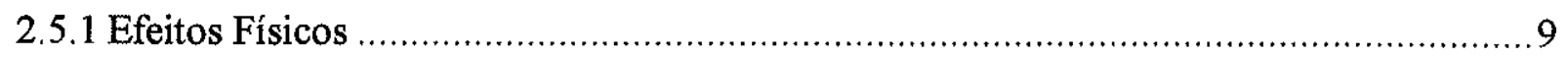

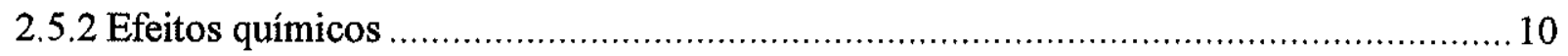

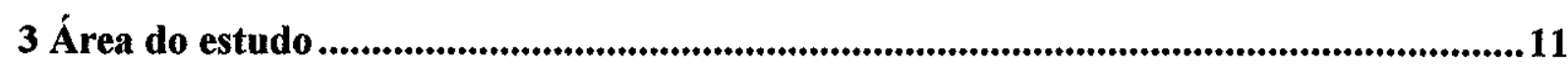

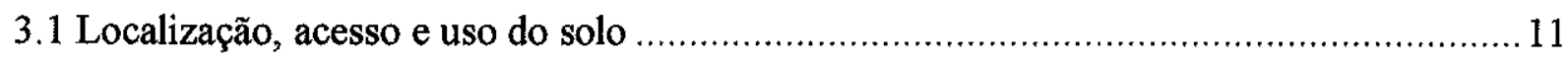

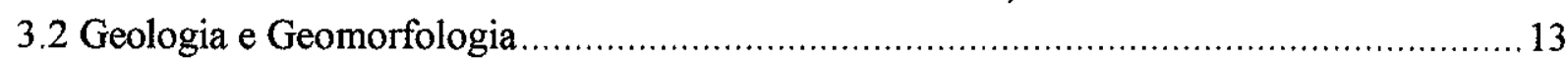

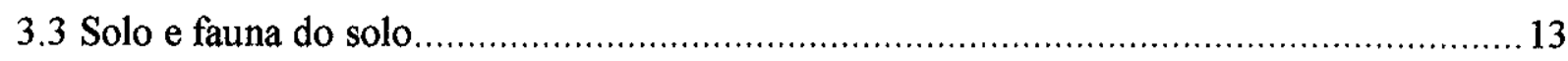

3.4 Clima

4 Metodologia ...................................................................................................................................... 17

4.1 Descrição macromorfológica do solo, dos cupins e amostragens no campo .....................17

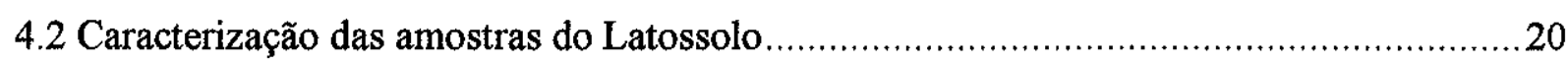

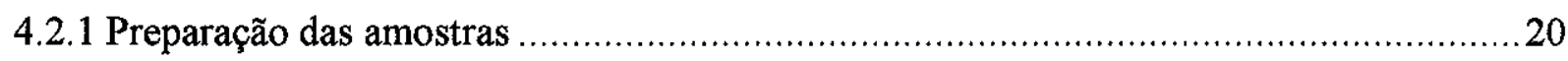

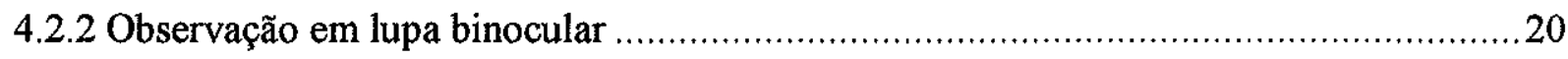

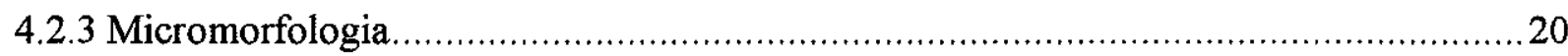

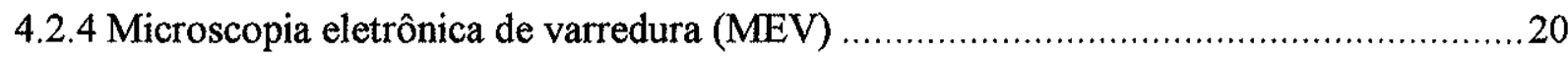

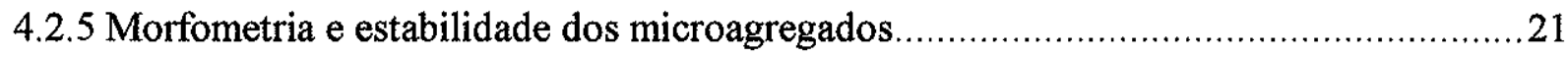

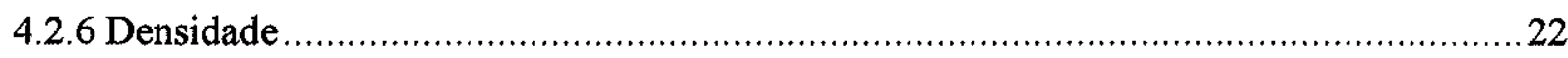

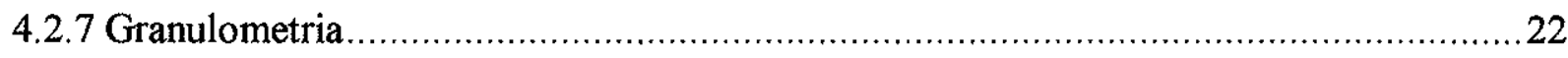

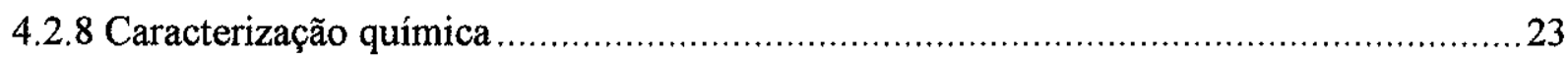

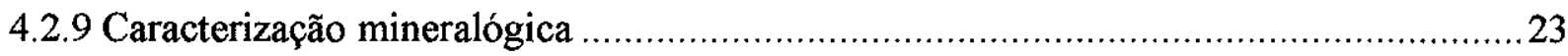


4.3 Caracterização das pelotas .23

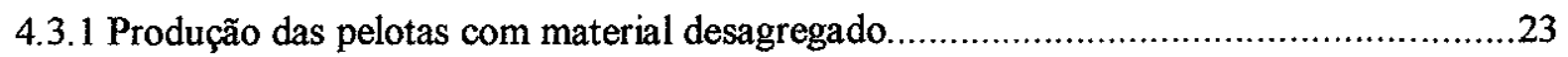

4.3.2 Desagregação mecânica das amostras de latossolo ...............................................24

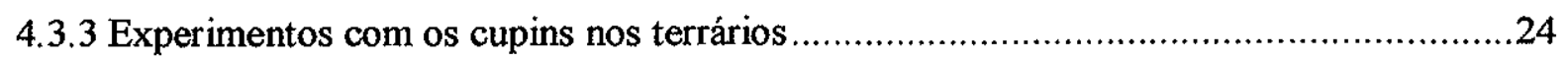

4.3.4 Morfologia das pelotas em lupa binocular e em MEV ..........................................26

4.3.5 Caracterização granulométrica, química e mineralógica das pelotas ...........................26

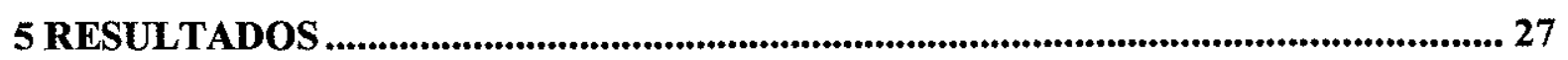

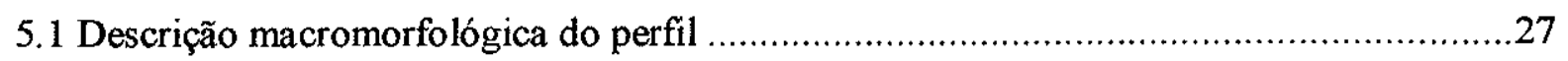

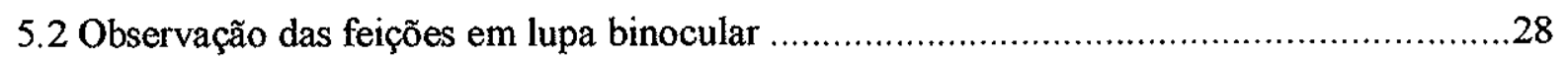

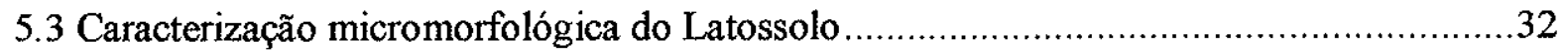

5.4 Observação dos microagregados por Microscópio Eletrônico de Varredura (MEV).........36

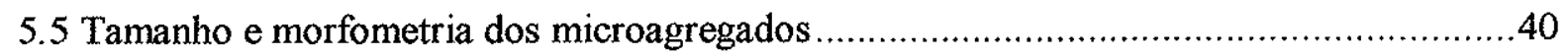

5.6 Caracterização da resistência dos microagregados à desagregação ...............................53

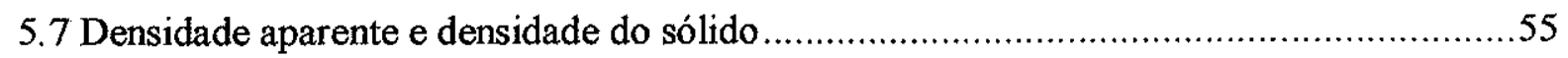

5.8 Distribuição do tamanho dos microagregados (experimentação por granulometria à laser).....56

5.9 Caracterização química dos microagregados do Latossolo ..........................................58

5.10 Caracterização mineralógica do Latossolo.........................................................61

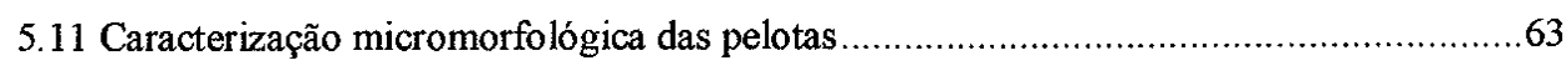

5.12 Observação das pelotas no Microscópio Eletrônico de Varredura (MEV) ....................67

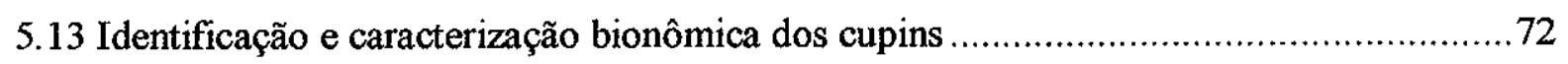

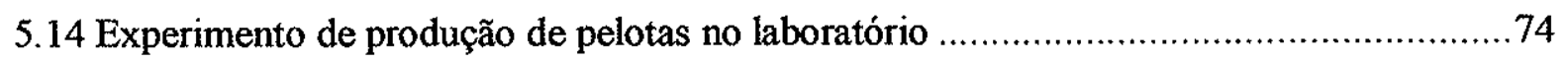

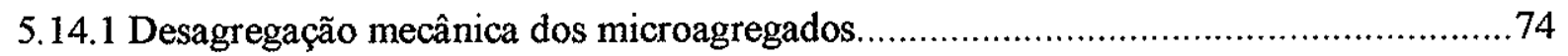

5.15 Morfometria das pelotas produzidas no campo e no laboratório...............................75

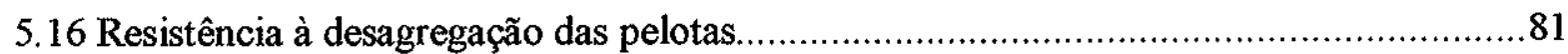

5.17 Distribuição do tamanho das pelotas (experimentação por granulometria a laser) .........82

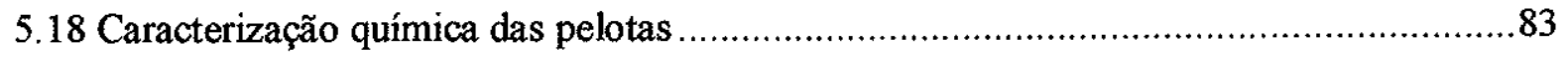

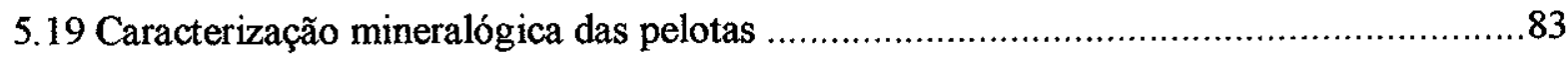




\section{INDICE DE FIGURAS}

Figura 1: Mapa de localização e acesso à área de estudo.

Figura 2: Mapa Geológico e perfil topográfico - geológico esquemático da área de estudo. .. 14

Figura 3: Precipitação e evapotranspiração em Piracicaba. 17

Figura 4: (a) Ninho de Cornitermes (b) Detalhe de montículo subsidiário de Syntermes. ...... 18 Figura 5: Esquema de amostragem em campo e das caracterizações no laboratório das amostras do Latossolo.

Figura 6: Eixos A, B, C medido para cada agregado. 21

Figura 7: Diagrama de Zinng, com curvas de igual esfericidade de Krumbein. 21

Figura 8: Ilustração do terrário de vidro utilizado nos experimentos no laboratório. 24

Figura 9: Protocolo utilizado para a desagregação com liquidificador. 25

Figura 10: Quadro de frequência de microagregados. 25

Figura 11: Feições observadas in situ no perfil do Latossolo 29

Figura 12: Feições observadas nas amostras do Latossolo. 30

Figura 13: Feições observadas nas amostras do Latossolo. 31

Figura 14: Microscopia ótica. (A) a (D) profundidade $0-10 \mathrm{~cm}$. 33

Figura 15: Microscopia ótica. (A) e (B), profundidade 40-50 cm.(C) e (D) $80-90 \mathrm{~cm}$. 34

Figura 16: Microscopia ótica. (A), (B) e (C) profundidade 110-120cm.. 35

Figura 17: Modo de assembléias secundária dos horizontes do Latossolo ...........................36

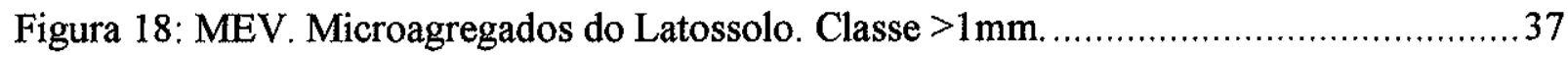

Figura 19: MEV. Microagregados do Latossolo. Classe $<0,053 \mathrm{~mm}$.. 38

Figura 20: MEV. Microagregados extraídos da parede de canal de cupins encontrados no Latossolo a $100-120 \mathrm{~cm}$ de profundidade. 39

Figura 21: Microagregados separados por fracionamento a seco. .... 41

Figura 22: Microagregados separados por fracionamento a seco. .42

Figura 23: Microagregados separados por fracionamento a seco. 43 
Figura 24: Morfometria ilustrada pelas razões B/A e C/B. profundidade 0-35cm e $40-60 \mathrm{~cm} .45$ Figura 25: Morfometria ilustrada pelas razões B/A e C/B. profundidade $80-120 \mathrm{~cm}$ e 100 $120 \mathrm{~cm}$ 46

Figura 26: Morfometria ilustrada pelas razões B/A e C/B. profundidade $160-200 \mathrm{~cm}$. 47

Figura 27: Arredondamento e esfericidade, profundidade $0-35 \mathrm{~cm}$. 48

Figura 28: Arredondamento e esfericidade, profundidade $40-60 \mathrm{~cm}$. .49

Figura 29: Arredondamento e esfericidade, profundidade $80-120 \mathrm{~cm}$. 50

Figura 30: Arredondamento e esfericidade, profundidade $100-120 \mathrm{~cm}$. A a D Curvas cumulativas da distribuição do arredondamento para cada classe. E a H Curvas cumulativas da distribuição da esfericidade para cada classe.

Figura 31: Arredondamento e esfericidade, profundidade $160-200 \mathrm{~cm}$. A a D Curvas cumulativas da distribuição do arredondamento para cada classe. E a H Curvas cumulativas da distribuição da esfericidade para cada classe. 52

Figura 32: Densidade aparente ao longo do perfil 55

Figura 33: Distribuição do tamanho dos microagregados do Latossolo, determinada por granulômetro a laser.

Figura 34: Variação da razão C/N. .60

Figura 35: Composição em óxidos totais. 60

Figura 36: Difratogramas de raio $X$ da fração argila. 61

Figura 37: Difratogramas de raio $X$ da fração argila. 62

Figura 38: Difratograma de raio $X$ da fração argila. .63

Figura 39: Microscopia ótica. Pelotas de Cornitermes produzidas no campo. 65

Figura 40: Microscopia ótica Pelotas de Comitermes e Syntermes produzidas no laboratório.....66

Figura 41: Peças bucais e mandibulares de operários de cupins. 67

Figura 42: MEV. Pelotas de Comitermes produzidas no campo. 68

Figura 43: MEV. Pelotas de Cornitermes produzidas no laboratório. 69

Figura 44: MEV. Pelotas de Cornitermes produzidas no laboratório com argila cinza. 70

Figura 45: MEV. Pelotas de Syntermes. 71

Figura 46: Morfologia da cabeça de soldados dos gêneros Cornitermes e Syntermes. 73

Figura 47: Observação em lupa binocular de amostras de Latossolo após desagregação ultra-sônica.. 74 
Figura 48: Observação em lupa binocular de amostras de Latossolo após desagregação no liquidificador.

Figura 49: Pelotas do campo e do laboratório 76

Figura 50: Morfometria ilustrada pelas razões B/A e C/B das pelotas produzidas no campo e no laboratório.

Figura 51: Curvas cumulativas da distribuição do arredondamento das pelotas dos cupins do laboratório e do campo.

Figura 52: Curvas cumulativas da distribuição da esfericidade das pelotas dos cupins do laboratório e do campo. .80

Figura 53: Distribuição do tamanho das pelotas produzidas no campo por granulometria à laser....82

Figura 54: Razão C/N para as pelotas de Cornitermes produzidas no laboratório 83

Figura 55: Difratogramas de raio $\mathrm{X}$ das pelotas de Cornitermes. .84

\section{INDICE DE TABELAS}

Tabela 1: Forma de microagregados a partir das razões B/A e C/B. 22

Tabela 2: Fracionamento dos microagregados em 4 classes granulométricas. 40

Tabela 3: Razão morfométrica B/A e C/B para os microagregados. 44

Tabela 4: Resistência à desagregação em diferentes condições hídricas. 54

Tabela 5: Composição química e granulométrica. 59

Tabela 6: Morfometria de operários adultos de Cornitermes e Syntermes, envolvidos nos experimentos em laboratório. 73

Tabela 7: Medidas dos diâmetros médios máximos (eixo A) e mínimos (eixo C) das pelotas de cupins de campo e de laboratório. .75

Tabela 8: Razão morfométrica $\mathrm{B} / \mathrm{A} \mathrm{e} \mathrm{C/B}$ para os microagregados. 77

Tabela 9: Ensaios de resistência à desagregação das pelotas de cupins de campo e laboratório em diferentes condições hídricas. 


\section{RESUMO}

A partir de década de 70, muitos pesquisadores descreveram semelhanças morfológica, química e mineralógica entre os microagregados de grande parte dos solos ferralíticos das regiões tropicais e as pelotas produzidas pelos cupins de solo, utilizadas para a construção do cupinzeiro. Tanto microagregados como pelotas apresentam-se como microestruturas com formas esferoidais a ovoidais e dimensão que varia de 0,5 a $3 \mathrm{~mm}$, com textura argilosa e composição mineralógica predominante de caolinita, gibbsita, oxihidróxidos de Ferro e grãos de esqueleto dispersos em uma matriz porfírica.

No Brasil, o Latossolo representa importante classe de solos, sendo peculiar o fato de apresentar o horizonte B com forte estrutura microagregada, muito estável e cuja gênese ainda não está completamente esclarecida. De outro lado, os cupins contribuem de forma intensa para os processos pedogenéticos dos solos tropicais através da remoção e concentração de partículas mineral e orgânica.

Este trabalho teve como objetivo caracterizar os microagregados de um Latossolo Roxo e verificar se ocorrem relações entre estes e as pelotas produzidas por cupins de larga ocorrência no estado de São Paulo. Foi realizada uma caracterização morfológica, química e mineralógica dos microagregados em um perfil de Latossolo Roxo na região de Piracicaba, bem como caracterização das pelotas produzidas por dois gêneros de cupins, Cornitermes e Syntermes, no campo e no laboratório. Os resultados mostram que no Latossolo ocorrem dois tipos principais de microagregados sendo um tipo maciço (sem subestrutura) e outro tipo composto (com subestrutura), em formas subesferoidais e contornos subarredondados a subangulosos, com dimensão predominante de 0,15 a $1 \mathrm{~mm}$.

A ação dos cupins no Latossolo fica evidente pela abundância de feições remanescentes no solo como, fragmentos de canal com ou sem preenchimento, marcas de remoção de argila impressas na superfície de feições argilosas, encontradas em todo o perfil $(0-200 \mathrm{~cm})$. As pelotas dos cupins, tanto de campo como de laboratório são muito similares na forma, ocorrendo um tipo maciço e um tipo composto (com subestrutura) com fábrica interna porfírica. A dimensão das pelotas varia entre 0,5 a $2,5 \mathrm{~mm}$ e indica uma relação direta com o tamanho da espécie produtora. Os resultados permitem concluir que o Latossolo apresenta diferentes tipos de microagregados, relacionados a gêneses distintas e refletindo processos complexos de evolução deste solo. A atividade de cupins é presente como um fator de transformação, sobretudo pela mistura e homogeneização de materiais no solo estudado. 


\section{ABSTRACT}

Since last 70 decade, many researchers have been describing morphological, chemical and mineralogical similarities among micro-aggregates assemblages under red or ferralitic soils of tropical areas and pellets produced by soil feeding termites during their constructive habits (nests, channels, chambers). Both micro-aggregates and pellets showed high stable assemblages with ovoidal to esferoidal shapes, roundness and diameter ranging from 0,5 to $3 \mathrm{~mm}$, with clay texture and mineralogical constitution with caolinite, gibbsite, oxihidroxide iron, and skeleton minerals in a porphiric fabric.

In Brazil, an important soil class, the Oxisol, shows a very strongly and stable microaggregated structure on B horizon, whose formation process is not completely understood at the present moment. On the other hand, termites produce intensive pedogenetic process in tropical soils through removal and concentration of minerals and organic particles.

Our work focus on characterization of a Oxisol profile and verify possible relationships among some micro-aggregates with termitic origin, specially termites with large geographical distribution on São Paulo State. To obtain this objective, was done a morphological, chemical and mineralogical characterization of Oxisol micro-aggregates profile, located in Iracemápolis, at Piracicaba region. The same methodology was used to characterize pellets produced by Cornitermes e Syntermes, collected in the field and produced in laboratory.

Our results show us differences in micro-aggregates assemblages in Oxisol profile, probably due to distinct genesis related with complex soil evolution process. Bio-aggregation by termites was evidencied on the Oxisol profile by pedologic features remains, like chamber and channel pedotubules along the profile $(0-200 \mathrm{~cm})$ and by the high morphological and mineralalogical similarity of some micro-aggregates assemblages, which permit to conclude that termitic activity is an importante factor to the pedoplasmation and pedoturbation as dinamic agents of these soil transformation. 


\section{INTRODUÇÃO e OBJETIVOS}

O Latossolo Roxo (LR), ocorre associado principalmente ao intemperismo de rocha vulcânica básica (basalto e diabásio). Esta classe de solos apresenta, em geral, perfil espesso (maior que 2 metros), poroso, bem drenado, de cor vermelha a roxa, muito homogêneo com pouca diferenciação entre seus horizontes. $O$ horizonte diagnóstico $B_{L}$ é muito friável e com forte estrutura microagregada (Comissão Nacional de Solos, 1960).

Esta classe distribui-se por uma área de aproximadamente $15 \%$ da superficie do Estado de São Paulo, localizada principalmente nas regiões das Cuestas Basálticas, Depressão Periférica e parte do Planalto Paulista. Apresenta grande importância para a economia do Estado, especialmente em função de seu uso intensivo nas culturas cafeeira e canavieira.

Os Latossolos correspondem aos Oxisols ou Ultisols da classificação norte americana (USDA, 1975) ou Ferralsols (FAO, 1971).

O entendimento sobre a gênese e o comportamento dos microagregados é essencial para o manejo adequado do solo. Inúmeros trabalhos, sobretudo na década de 70 , foram realizados visando entender os processos de formação desses microagregados onde, a partir da herança geoquímica da rocha básica, por concentração dos óxidos e hidróxidos de ferro sobre núcleos cauliníticos, formariam microagregados esferoidais ou ovoidais, muito estáveis. Vários autores consideram que estes microagregados são formados por microfissuração da alterita, promovida por sucessivos ciclos de hidratação-ressecamento e pedoplasmação. Por outro lado, trabalhos realizados notadamente no continente africano, demonstraram que as pelotas produzidas por cupins apresentam características (dimensão, forma e fábrica interna) muito similares aos microagregados dos Latossolos, o que conduziu à hipótese que a microagregação pela atividade biológica de cupins seria um processo relevante para a microagregação dos solos tropicais.

Como objetivo principal deste trabalho, realizou-se uma caracterização morfológica, química e mineralógica dos microagregados de um Latossolo Roxo e de pelotas produzidas por cupins no campo e no laboratório, identificando tipos principais de microagregados e de pelotas. 


\section{REVISÃO DA LITERATURA}

\subsection{Considerações principais sobre a gênese e caracterização do Latossolo Roxo}

As rochas vulcânicas básicas, ricas em silicatos ferro-aluminosos, quando se alteram sob condições tropicais, resultam em um manto de alteração profundo que evolui para um solo ferralítico vermelho, muito argiloso, rico em argilominerais $(1: 1)$ e oxihidróxidos de ferro e alumínio.

Gonçalves (1987), estudando os produtos de alteração intempérica in situ de basaltos toleíticos na região de Ribeirão Preto (SP) observa que, no período inicial da alteração a transformação ocorre no contato entre minerais primários, acarretando o aparecimento de uma rede microfissural, sem orientação preferencial, com diminuição da densidade, aumento da percolação de soluções e posterior deposição de produtos secundários neoformados constituídos por oxihidróxidos de ferro e alumínio e argilominerais, principalmente caolinita. A proporção elevada em oxihidróxidos é resultante sobretudo da alteração dos minerais ferromagnesianos (piroxênios, anfibólios e olivinas), enquanto os argilominerais são principalmente produtos de alteração dos plagioclásios. O fácies aloterita dessas alterações e os horizontes do solo apresentam forte pedoturbação com predomínio de uma matriz argilosa, recortada por canais discordantes e litorelíquias dispersas. Neste conjunto observa-se transformação intempérica ascendente in situ dos constituintes primários da rocha que alimentam o fundo matricial do solo. Neste mesmo estudo, Gonçalves conclui que os horizontes Latossólicos apresentam filiação direta no perfil, a partir da microfissuração do plasma argilasépico formando microagregados individualizados, esféricos de diâmetro inferior a $100 \mu \mathrm{m}$ e constituídos essencialmente por caolinita, gibbsita, hematita, quartzo e minerais pesados (magnetita e ilmenita).

Quanto às propriedades diagnósticas, o Latossolo Roxo (Comissão Nacional de Solos, 1960), antigamente referidos na literatura como "Terra Roxa Legítima", são solos de difícil diferenciação de seus horizontes no campo por apresentar transições graduais a difusas e coloração muito uniforme ao longo do perfil, variando de vermelho-acinzentado escuro (10 R 3/4) a vermelho-escuro (2,5 YR 3/6) segundo Oliveira \& Menk (1984).

Amostras de solo apresentam baixo grau de coesão quando secas, destorroando-se facilmente sob leve pressão dos dedos em um material granular muito fino e estável, que é reconhecido pelo tato como textura "pseudo-arenosa ou pseudo-siltosa", também denominada 
por "estrutura pó de café" (Pedro et al., 1976). Esta estrutura corresponde a microagregados de forma esférica a ovoidal e diâmetro que varia de 0,03 a $1 \mathrm{~mm}$, encontrados ao longo de todo o perfil, mas principalmente concentrados a partir do horizonte $B_{L}$.

Em termos analíticos, os Latossolos apresentam textura argilosa a muito argilosa com 40 a $60 \%$ de argila e teor de areia fina a média inferior a $10 \%$ do peso total. O plasma é constituído por caolinita, gibbsista e em menor proporção clorita-vermiculita, além de oxidróxidos de ferro e alumínio. $O$ esqueleto é constituído predominantemente por quartzo (com teor entre 1 a $6 \%$ do peso total) e minerais primários da rocha básica (magnetita e ilmenita) (Melfi, 1967; Camargo et al., 1987).

\subsection{Síntese sobre processos de microagregação de partículas}

Sudo (1962) propõe que partículas individualizadas (menores que $20 \mu \mathrm{m}$ ) de argila e matéria orgânica se unem formando partículas secundárias estáveis entre 20 a $60 \mu \mathrm{m}$.

Edwards \& Bremner (1967) apresentam que a unidade estrutural primária de formação de um agregado estável, na maioria dos solos, corresponde à um arranjo complexo do tipo argilametal polivalente-matéria orgânica, representado como [(C-P-OM)x]y, onde $\mathrm{C}=$ partícula mineral de argila, $\mathrm{P}=$ metal polivalente $(\mathrm{ex} . \mathrm{Ca}, \mathrm{Al}, \mathrm{Fe}$ ), $\mathrm{OM}=$ complexos organo-metálicos (substâncias húmicas com metais polivalentes associados), e $\mathrm{x}$, $\mathrm{y}$ são números finitos de agrupamentos destas unidades. Estas unidades estruturais C-P-OM apresentam dimensões mínimas de $2 \mu \mathrm{m}$ e estabilizam-se em agrupamentos entre 20 a $250 \mu \mathrm{m}$.

Emerson (1986) reconhece que a formação de um agregado estável não se dá somente pelo agrupamento de unidades do tipo C-P-OM e descreve um primeiro estágio de agregação de partículas através da floculação entre unidades de argilominerais, a qual se processa sob condições físico-química (temperatura, $\mathrm{pH}$ ) específicas. Este estágio primário de agrupamento de argilominerais é responsável pela formação de domínios individualizados de dimensão entre 0,1 a $20 \mu \mathrm{m}$, muito estável quando ressecados.

Tisdall \& Oades (1982) discutem que diferentes agentes ligantes podem atuar na junção destas partículas, desde polímeros orgânicos, polissacarídeos, carboxilas até óxidos amorfos (de Fe e Al principalmente) e aluminosilicatos, que podem atuar isoladamente ou em conjunto. A interação entre a superfície do argilomineral e a matéria orgânica é complexa e envolve pontes de cátions polivalentes interagindo conjuntamente na superfície das argilas e no composto orgânico. 
As pontes de ligação destas partículas microagregadas podem ser rompidas por vibração ultrasônica ou por tratamentos químicos (solução aquosa de hidróxido sódio, por exemplo), possibilitando a determinação analítica das unidades elementares dos microagregados (Edwards \& Bremner, 1967; Tisdal \& Oades, 1982).

Agregados estáveis em água tornam o solo poroso e aerado, permitindo a ocupação microbiana do vazios, que por sua vez exercem um papel importante na arquitetura dos microagregados (Singh \& Singh, 1995; Monreal \& Kodama, 1997; Monreal et al., 1997).

A participação de agentes biológicos no solo ocorre em diferentes escalas e contribuem para o incremento da matéria orgânica no meio, atuando na agregacão de partículas dos solo sob três formas distintas: entre partículas primárias livres (partículas de argilas, grãos de silte e areia), entre microagregados e entre macroagregados (Tate \& Theng, 1977; Tisdall \& Oades, 1982; Singh \& Singh, 1995, Elliot \& Panstrank, 1999).

Na formação de microagregados, Tisdall \& Oades (1982) observam por exemplo que, agrupamentos de bactérias (de 2 a $20 \mu \mathrm{m}$ ) ocorrem unidos tangencialmente à distâncias de $0,1 \mu \mathrm{m}$, com sua superfície recoberta por uma película de carbohidrato misturado com placas de argilas ligando firmemente estes agrupamentos, formando microagregados estáveis no solo.

Hifas ou esporos de fungos, desenvolvidos principalmente na rizosfera, participam como agentes ligantes dos microagregados e também contribuem no incremento da matéria orgânica do solo (polissacarídeos) que, posteriormente servem como alimento para organismos de níveis superiores da fauna do solo (nemátodos, ácaros, colêmbolos, minhocas e cupins) (Lavelle, 1994).

Noirot (1970), Lee \& Wood (1971) e Lavelle (1994) observam que especialmente os cupins contribuem de forma direta na formação de microagregados nos solos tropicais, pela mistura de materiais do meio ambiente (orgânicos e/ou minerais) com excrementos e saliva processados no trato bucal e digestivo, sendo posteriormente incorporados ao solo sob a forma de pelotas bucais ou fecais.

\subsection{Gênese dos microagregados do Latossolo}

Os primeiros trabalhos que fizeram referência sobre microagregados dos solos ferralíticos foram realizados no continente africano (Brewer, 1964; Beaudou, et al.,1977; Muller, 1977; Eswaram \& Buol, 1978; Chauvel et al., 1978; Eschenbrenner, 1986; Trapnell \& Webster, 1986).

A gênese e o modo de formação dos microagregados nestes solos ainda não são completamente estabelecidos, sendo objetos de vários estudos que, em geral, admitem a 
possibilidade de origem diversa ou complexa. Stoops \& Buol (1985) distinguem cinco tipos de microagregados com pedogêneses distintas, sendo 1) estruturais (Beaudou et al., 1977; Muller, 1977); 2) zoogenéticos; 3) reliquiais (Stoops, 1967); 4) de origem geoquímica (Chauvel et al., 1978); 5) complexos (Muller, 1977).

Os fatores climáticos parecem não definir tipos específicos de microagregados, pois são encontrados microagregados em solos sob áreas tropicais úmidas, secas e até mesmo áreas frias elevadas (Muller, 1977).

Da mesma forma, Trapnell \& Webster (1986) sugeriram que não ocorrem relações entre o material parental (rocha) e microagregados, visto que, diferentes tipos de solos formados sobre rochas ácidas (granito, gnaisse e arenito) como sobre calcário, diabásio ou fonólito, podem desenvolver tipos de microagregados variados, com formas (de esferoidais a angulosos) e graus de estabilidade distintos.

Os autores destacaram neste mesmo trabalho que, microagregados esferoidais e ovoidais ocorrem com maior frequência em áreas tectonicamente estáveis, com relevo aplainado e altitude elevada, enquanto microagregados fragmentados ocorrem em áreas tectonicamente instáveis e declives acentuados. Estas observações sugerem que o fator tempo poderia exercer importante papel na preservação e acúmulo dos microagregados formadores dos solos tropicais.

Morfologicamente são reconhecidos nos Latossolos dois tipos principais de microagregados: ovoidais/esferoidais e os microagregados poliédricos. A discussão sobre estes últimos está melhor definida uma vez que estes microagregados é resultado da fragmentação mecânica do fundo matricial contínuo denso (porfírico), (Beaudou et al., 1977; Miklos, 1992; Ladeira, 1995) causado por sucessivos ciclos de expansão e contração do plasma argiloso, ligados a alternância de períodos úmidos e secos (hidratação e ressecamento) durante o Holoceno (Miklos, 1992; Pessenda et al., 1996; Vidal-Torrado et al., 1999).

Miklos (1992) defende que os microagregados poliédricos resultam de uma evolução ascendente no perfil, onde a partir de um fundo matricial porfírico ocorre formação de microfissuras e cavidades irregulares que evoluem para uma assembléia porfirica com desenvolvimento de porosidade intra-agregado, disjunção plasma-esqueleto e reorganização do fundo matricial microgranular. Esta transformação, de idade holocênica, seria resultado da última exposição climática contrastada sofrida por este solo. 
Para os microagregados esferoidais/ovoidais a questão apresenta-se mais complexa, sendo apresentadas diversas hipóteses, tendo como principais uma que defende a gênese geoquímica $\mathrm{e}$ outra sobre a gênese zoogenética.

\subsubsection{Gênese geoquímica}

Chauvel \& Pedro (1978), a partir de estudos em solos ferralíticos do Senegal, demonstram que a microagregação resulta de interação físico-química entre óxidos de ferro e caolinita, a partir da concentração centrípeta de ferro, formando um arranjo isótropo destas partículas, com forma externa ovóide, micronodular com $100 \mu \mathrm{m}$ de diâmetro em média. Esta assembléia é considerada com resultado do processo de ferralitização.

Beaudou et al., (1977), apresentam uma síntese da microagregação desenvolvida sobre rochas básicas e propõem que, para os solos ferralíticos vermelhos, os microagregados ovoidais/esferoidais seriam resultado da combinação dos argilominerais com hematita. A argila presente nos microagregados apresenta orientação paralela à borda, com pedofábrica interna do tipo oosépica, cuja formação ocorre a partir da região vermelho amarelo da assembléia plásmica (masépica ou ma-latisépica), com fragmentação progressiva do fundo matricial por sucessivos ciclos de expansão e contração das argilas.

Concordantemente, Pedro (1976), demonstra que a formação dos microagregados é uma tendência de contração hidrofóbica dos íons $\mathrm{Fe}$ e $\mathrm{Al}$, que formam um arranjo de maior estabilidade e superfície externa mínima na forma esferoidal a ovoidal.

\subsubsection{Gênese das pelotas pela atividade de cupins}

A similaridade das pelotas produzidas pelos cupins com os microagregados esferoidais/ovoidais dos solos ferralíticos, ocorre principalmente em relação à dimensão (diâmetro, comprimento), forma (esferoidal, ovoidal) e fábrica interna (arranjo plasmaesqueleto), além de porosidade intra e intermicroagregado. Nos solos com microrganização do tipo aglutinic marcada pela forte coalescência de microagregados, é freqüente a ocorrência de alta densidade de canais e câmaras de cupins dispersos no solo (Eschenbrenner, 1986; Goudie, 1988; Miklos, 1992; Eschenbrenner, 1988; Jungerius et al., 1999).

Miklos (1996), reconhece várias evidências a favor da origem biológica dos microagregados do Latossolo no local, tais como: 
- presença de horizontes escurecidos sombric horizons, com altos teores de matéria orgânica e forte microagregação em profundidade, interpretado como resultado de atividade de remonte e acumulação por cupins.

microagregados ovoidais em todos os horizontes latossólicos.

presença de cupins endógenos ativos no contato do solo com a alterita (cerca de $4 \mathrm{~m}$ de profundidade).

presença de litorelíquias arredondadas $(0,1-1 \mathrm{~mm})$ de fácies alteritas nos horizontes do solo.

- $\quad$ alta densidade de câmaras e canais no perfil.

- $\quad$ presença de fragmentos de carvões internos aos microagregados.

- triagem granulométrica do esqueleto interno dos microagregados.

A ocorrência de atividade de cupins associados à regiões tropicais é conhecida como atuante desde o Cretáceo Inferior (130 M.a.) (Cloud, 1980; Martinez-Declos \& Martinell, 1995), o que reforça a hipótese que, a intensa microagregação dos solos ferralíticos atuais possa estar ligada em grande proporção à atividade da fauna como processo pedogenético cumulativo no tempo geológico sobretudo em áreas antigas e estáveis tectonicamente (Trapnell \& Webster, 1986).

Considerando a hipótese da "bioagregação" como um fator de gênese dos microagregados ovoidais/esferoidais dos solos tropicais, dois aspectos principais devem ser analisados em relação à atividade dos cupins sobre os solos. O primeiro, refere-se ao modo de escavação e construção; e o segundo, relaciona-se aos efeitos destas construções sobre os solos.

\subsection{Atividade escavadora e construtora}

Aproximadamente 2000 espécies de cupins são conhecidas, a maioria vivendo em regiões tropicais e subtropicais, sob regimes climáticos que variam de hiperúmido (floretas chuvosas) ao árido (vegetação xeromórfica). Os cupins constituem o grupo majoritário da macrofauna dos solos tropicais (Lee \& Wood, 1971; Grassé, 1984) e mantém estreita relação com o solo através da construção do ninho e do sistema de câmaras e galerias que se prolonga e ramifica a partir do ninho. As principais funções destas construções são: 1) encontrar áreas de alimentação e 2) obter material para construção, ampliação e manutenção dos ninhos. Algumas espécies não apresentam construção de ninhos, vivendo dispersos sob serapilheira ou até fezes de animais (Jordan, 1988; 
Goudie, 1988). O conhecimento sobre a ecologia e comportamento da maioria dos grupos ainda é reduzido, podendo ocorrer muitas particularidades de comportamento entre as espécies.

A natureza das partículas removidas do solo varia de acordo com a espécie e o tipo de substrato explorado e esta atividade se dá por dois mecanismos principais: remoção e construção (Noirot, 1970).

As partículas removidas diretamente do solo podem ser desde grãos minerais à partículas orgânicas, fragmentos vegetais ou até mesmo pelotas pré-existentes (Grassé, 1984). O trabalho de remoção é executado unicamente pelos operários com o uso das mandíbulas que, em geral, são curtas, fortemente quitinizadas, curvas, achatadas e assimétricas. As características morfológicas das mandíbulas muitas vezes refletem os hábitos alimentares e de forrageamento específico de uma espécie (Grassé, 1984). A umidade e a textura do solo são essenciais para garantir a eficiência do trabalho de remoção de partículas uma vez que, solos muito arenosos e muito secos dificultam o trabalho. Muitas vezes os indivíduos precisam descer até o contato do lençol freático ou horizontes inferiores do solo para obtenção de materiais com características construtivas ideais (Machado, 1983; Noirot, 1970).

Para construção do ninho, que pode ser epígeo (superficial), hipógeo (subterrâneo) ou arbóreo (em madeira viva ou morta), o método adotado pela grande maioria das espécies é muito similar (Grassé, 1984; Eschenbrenner, 1986).

As partículas removidas sofrem uma seleção granulométrica em geral nas frações de areia (0,5-3 mm), controlada pelo tamanho da abertura máxima das mandíbulas, as quais não podem ser ingeridas. Partículas menores (em torno de $0,1 \mathrm{~mm}$ ) podem ser ingeridas, pórem são controladas pelo tamanho do cibarium e do intestino do operário de cada espécie.

O material retido na cavidade bucal é umidecido com saliva e, em estado plástico, é moldado sob pressão do hypopharynx, sendo regurgitado sob a forma de pelota pastosa, esferoidal a ovoidal, dimensão entre 0,2 a $2 \mathrm{~mm}$ de diâmetro e 0,2 a $3 \mathrm{~mm}$ de comprimento (Eschenbrenner, 1996).

Eventualmente partículas minerais maiores podem ser aglutinadas na massa da pelota ainda pastosa ou na superficie.

No caso do material ingerido, este passa por todo o sistema digestivo dos operários sendo posteriormente excretado sob a forma de pelotas fecais (em geral em forma de bastonete) que podem ser utilizados como material cimentante das pelotas, material de revestimento de câmaras e canais, ou ser acumulados ao longo das câmaras sem uma função conhecida, possivelmente 
como material de estoque ou reposição. Uma mesma espécie é capaz de elaborar diferentes tipos de pelotas em forma e dimensão variada (Eschenbrenner, 1986), que devem variar com a função e com a disponibilidade de material no momento da produção das pelotas (Noirot, 1970; Mermut et al. 1984).

Muitos fatores ambientais influenciam a arquitetura da construção dos ninhos. Mermut et al. (1984) constatam que sob condições de clima, vegetação e substrato rochoso similares, diferentes espécies de cupins tendem apresentar comportamento construtivo muito similares, enquanto uma mesma espécie sob solo e clima diferentes apresenta comportamento diferente e arquitetura dos ninhos distinta, revelando a importância dos fatores externos nas características bionômicas das diferentes espécies.

Análises micromorfológicas de materiais de cupinzeiros ativos (Stoops \& Buol, 1985; Lee \& Wood, 1971, Mermut et al. 1984) indicam que, durante a atividade construtora dos ninhos pelos operários, estes exercem pressão com o hypopharynx sobre a pelota cimentada, resultando em diferentes microfábricas na construção (parede do ninho, galerias, etc).

\subsection{Efeito da atividade dos cupins sobre os solos}

Como efeitos principais da atividade dos cupins sobre os solos podem ser reconhecidos os efeitos físicos e químicos, conforme discutidos a seguir:

\subsubsection{Efeitos Físicos}

Eschenbrenner (1996) reconhece que o efeito da escavação dos cupins afeta o solo em relação a pedoplasmação, migração vertical e concentração de seixos e cascalhos.

Jungerius et al. (1999) descrevem os efeitos da atividade dos cupins na formação dos horizontes superficiais do solo, a partir da incoporação gradativa de microagregados, causada pela erosão de cupinzeiros abandonados.

A porosidade sofre modificação pela atividade dos cupins como consequência do empacotamento das pelotas durante a construção do ninho. Eschenbrenner (1986) reconhece quatro estágios de compactação entre os microagregados que afetam na porosidade:

- arranjos livres de pelotas justapostas, localmente soldados com forte porosidade de empacotamento.

- microagregados soldados com forte coalescência e numerosos poros policôncavos interconectados. 
- microagregados não individualizados com vestígios de porosidade mamelonar anterior.

- microagregados com coalescência completa, onde não é possivel distinguir porosidade no fundo matricial.

\subsubsection{Efeitos químicos}

Dentre as propriedades químicas destacam-se:

$\mathrm{pH}$ : Diferentes correlações tem sido determinadas comparando-se os valores de $\mathrm{pH}$ dos cupinzeiros com os dos solos do entorno, muitas vezes indicando acréscimos nos valores (por incremento de bases trocáveis associadas aos argilominerais concentrados) e em outros casos apresentando decréscimo do pH associado a concentração de matéria orgânica (Lee \& Wood, 1971). Soares (1999) determinou aumento do $\mathrm{pH}$ em cupinzeiros com elevado acúmulo de matéria orgânica.

Matéria orgânica, Carbono Total e Nitrogênio Total: A maioria dos cupinzeiros apresenta teores de carbono orgânico superiores aos do solo do entorno. Isto pode ser entendido pelo fato que muitas espécies de cupins utilizam seus próprios produtos orgânicos (saliva e fezes ricas em matéria orgânica), nas atividades de cimentação de partículas para construção dos ninhos. Estruturas específicas como as câmaras de ovos ou do casal real são construídas totalmente com material cartonado escuro, constituído essencialmente de material celulósico. Canais e câmaras também podem apresentar revestimento interno das paredes com material escuro orgânico (Lee \& Wood, 1970; Grassé, 1984). A matéria orgânica eliminada pelos cupins consiste principalmente de produtos finais da digestão de tecidos vegetais, algumas vezes com fragmentos não digeridos, incorporados nas pelotas fecais.

O processo de digestão da matéria orgânica ingerida pelos cupins é complexo. Lavelle (1994) propõe que a maioria dos grupos de cupins superiores, que não apresentam capacidade de digestão da celulose, desenvolvem uma relação de simbiose com microorganismos do solo baseados na seguinte estratégia:

Os cupins provocam o fracionamento e a mistura de matéria orgânica e mineral na cavidade bucal e no trato intestinal, produzindo uma mistura hidratada de compostos orgânicos (celulose, lignina, tanino-proteínas) e partículas minerais que são finalmente excretadas. $O$ arranjo externo e interno destas pelotas gera microporosidade que serve como nicho para ocupação de microorganismos (fungos, bactérias). A atividade microbiana incubada e sob um meio nutritivo apropriado, promove a digestão bioquímica dos compostos orgânicos complexos 
em compostos assimiláveis pelos cupins, os quais periodicamente reingerem seus próprios materiais (pelotas e excretas) passando então a assimilarem estes compostos maturados. Esta atividade dinâmica promove uma interação contínua entre materiais constituintes do solo reincorporados com compostos já maturados, implicando um significativo processo de pedoplasmação no solo.

A dosagem dos elementos carbono orgânico e o nitrogênio em cupinzeiros indicam em geral um incremento nos cupinzeiros em relação ao solo local. Tecidos vegetais, húmus e madeira em decomposição contêm pouco nitrogênio e observa-se que, em geral, cupins comedores de gramíneas (seca ou verde) apresentam relação $\mathrm{C} / \mathrm{N}$ menor do que para cupins comedores de madeira (viva ou morta) (Lee \& Wood, 1971).

\section{3 ÁREA dO ESTUdO}

Para o presente estudo, foi selecionada uma área na região de Iracemápolis, a qual apresenta uma cobertura de Latossolo Roxo desenvolvida sobre rocha básica em posição topográfica de topo a ombro de encosta, com cobertura vegetal local de bosque de eucaliptos (ausente de manejo mecanizado há 50 anos).

A característica do posicionamento topográfico, de topo ou ombro de encosta, é importante pois é nesta posição onde ocorre o desenvolvimento vertical máximo do perfil, sem interferência de acúmulo coluvionar de montante.

A cobertura vegetal arbórea ausente de manejo agrícola contribui para manutenção das propriedades fisicas e estruturais do solo e para o aumento da atividade biológica.

\subsection{Localização, acesso e uso do solo}

A área de estudo (Figura 1) localiza-se entre os municípios de Limeira-Iracemápolis, com acesso pela Rodovia SP-306 (Iracemápolis-Santa Bárbara d'Oeste). Na região predomina cultura de cana-de-açúcar. $\mathrm{O}$ local onde foi realizada abertura da trincheira, para estudo e amostragem do Latossolo Roxo, corresponde a um bosque de eucaliptus de 0,25 ha com cerca de 58 anos de idade. Anteriormente à cultura do eucaliptus, o local foi utilizado com culturas de café e algodão.

No interior da área de eucaliptus ocorrem outras espécies arbóreas em enor proporção. A cobertura superficial $(0-15 \mathrm{~cm})$ do solo do bosque é de serapilheira e gramíneas associadas. 

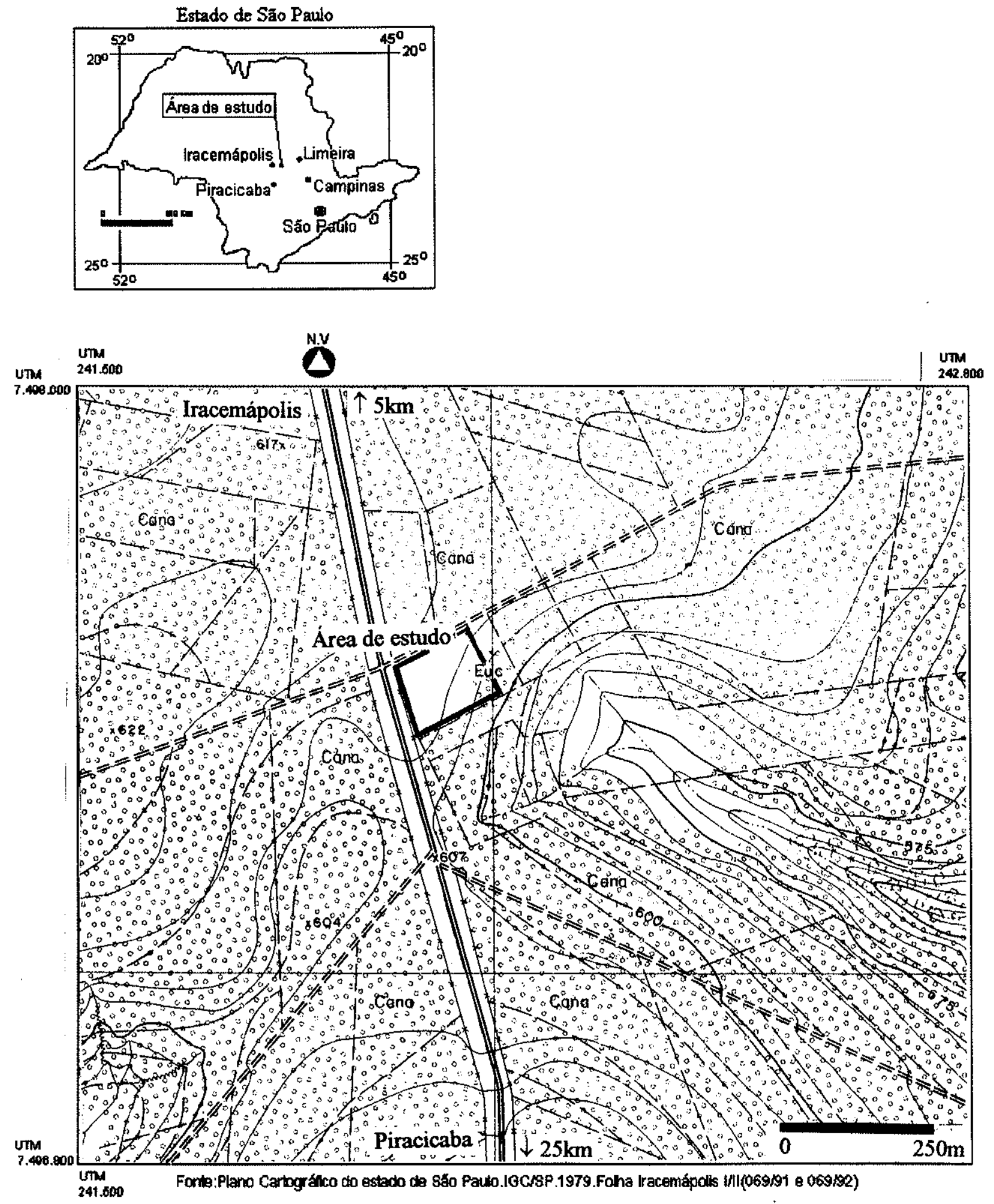

Figura 1: Mapa de localização e acesso à área de estudo. 
A cobertura vegetal original da região era composta predominantemente por floresta arbórea, classificada como floresta estacional semidecidual caracterizada pela mistura de espécies caducifólias e perenifólias sendo atualmente raros testemunhos da vegetação primária (Nascimento et al., 1999). Pequenas e espaçadas áreas de vegetação arbórea densa são ainda observadas na região ao longo das drenagens maiores.

\subsection{Geologia e Geomorfologia}

$\mathrm{Na}$ região estudada ocorre uma sucessão de rochas intrusivas constituídas sobretudo por sills e diques de composição basáltica toleítica, associadas aos derrames contínuos e espessos da Formação Serra Geral (Grupo São Bento de idade Juro-Cretácica, 120-130 Ma.).

No mapa geológico da Figura 2, observa-se que no local do estudo ocorre uma rocha básica, descrita no campo como um diabásio maciço, subfanerítico, holocristalino com coloração da matriz verde escura a preto, ressaltando as ripas de plagioclásios esbranquiçados (nas partes alteradas). Em perfil, esta rocha recobre em contato abrupto e subhorizontal, um arenito fino siltoso, com estratificação plano paralela, com coloração mosqueada vermelho a arroxeada, identificado como pertencente à Formação Corumbataí (Grupo Passa Dois).

Segundo a divisão geomorfológica do Estado de São Paulo (IPT, 1981), esta área insere-se no Domínio da Depressão Periférica, na zona do Médio Tiête, onde predominam relevos de degradação, com morros, morrotes e colinas de encostas suavizadas. Localmente, formam-se colinas amplas com baixa declividade $(<15 \%)$, amplitude local inferior a $100 \mathrm{~m}$, topo extenso, aplainado, vertente com perfis convexos a retilíneos, planície aluvial restrita e localmente lagoa perene. Dois tipos de perfil topográfico formam a vertente no local de estudo:

- perfil convexo localizado na porção média superior da vertente onde se insere o bosque (ombro da encosta);

- perfil retilíneo-côncavo na porção média a baixa da vertente, onde localiza-se a cabeceira da drenagem local.

\subsection{Solo e fauna do solo}

A montante da cota altimétrica de $570 \mathrm{~m}$ de altitude, ocorre a cobertura latossólica (Latossolo Roxo no topo e Latossolo Vermelho Escuro na porção mediana da vertente).

A transição entre rocha básica e o Latossolo não foi observada no campo. Encontra-se em seções ao longo da rodovia SP-304, perfis de solo profundo (de até $8 \mathrm{~m}$ de profundidade) em 

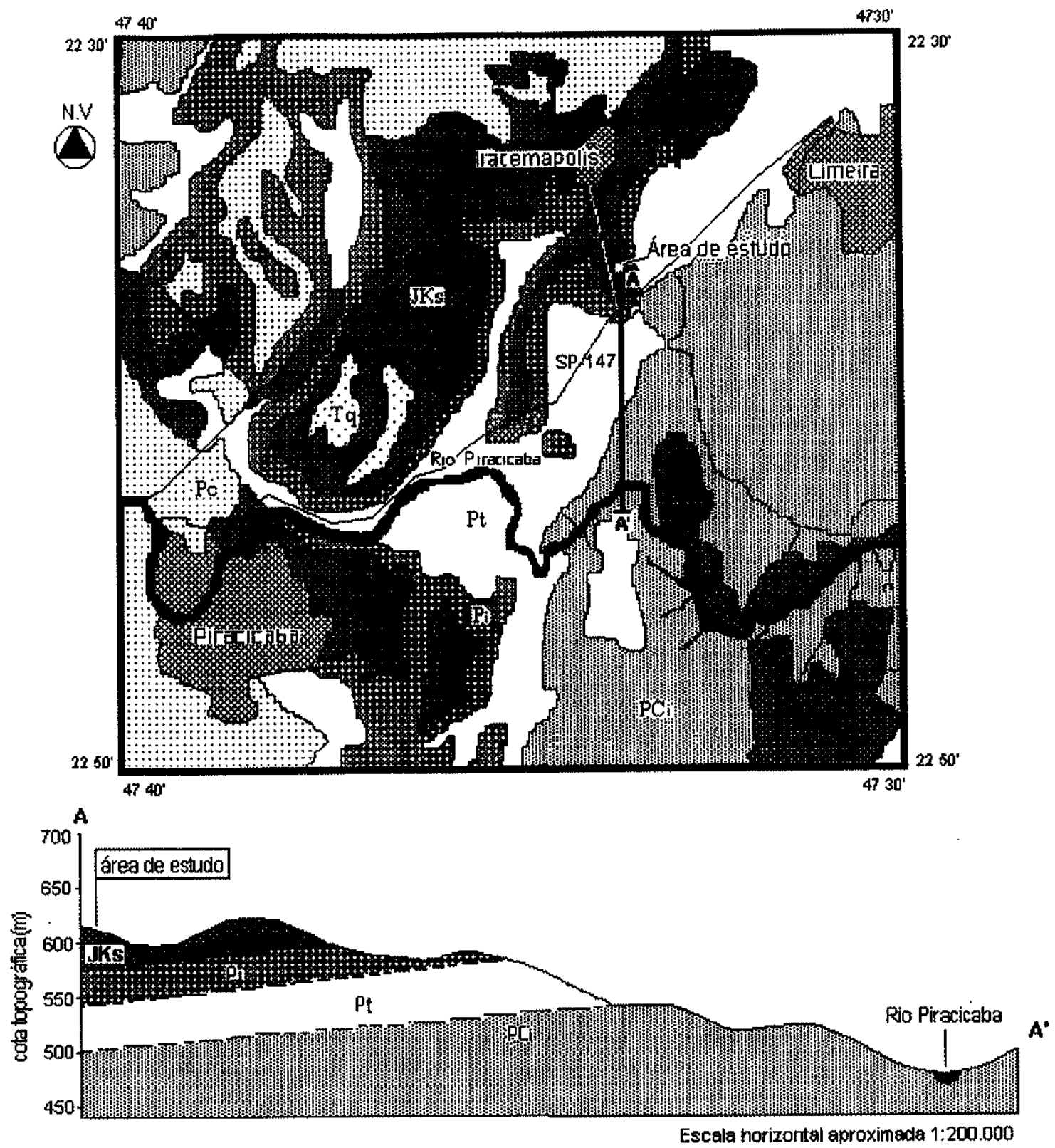

\section{LEGENDA}

T.9. Coberturas aluvionares [sedimentos arenosos e argibsos inconsodidados]

Ulks: Surtes básicas, "sill" de cliabásio, composiçẫo basática

Pot: Formaçto Irati. Sittos, argiltos cor ocre amarelacka

Pt Formaçễo Tatuí. Siltitos, arenitos finos, com estratiticą̧áo plano-paralela, cor ocre vermetha arroxeada

Fomaçẩo ltararéfAquichauena. Sittitos, folhehos, arenitos finos, cor vermelho aroxeados

Formaçấo Corumbstá. Arenito fino, intercalado com níveis de sitito de cor llís ocre mosqueado

área urbara

Fonte: Carta Geológica do Estado de Säo Paưo. Folha Campinas, escala 1:250.000 (DAEERHESP Rio Claro, 1982)

Figura 2: Mapa Geológico e perfil topográfico - geológico esquemático da área de estudo. 
contato direto com os sedimentos areno-siltosos arroxeados, da formação Corumbataí, o que sugere uma alteração e uma pedogenização total do sill.

Os Latossolos desta região foram mapeados em escala de semi detalhe (1:50.000) como pertencentes a Unidade Barão Geraldo (Oliveira \& Menk, 1984), e caracterizados como Typic Haplorthox (USDA, 1975), Rhodic Ferralsol (FAO, 1971) com horizonte A moderado e textura muito argilosa ou argilosa.

Diferentes espécies animais foram identificadas no solo do local de estudo, tanto pela atividade dos organismos, como através dos efeitos sobre o solo (galerias, montículos). As seguintes espécies foram observadas:

De vertebrados foram encontradas 10 cavidades de tatu, abertas ou parcialmente preenchidas na entrada, oblíquas em relação à superficie e com seção 20 a $30 \mathrm{~cm}$ de diâmetro. Em geral, encontram-se próximas a sauveiros ativos ou diretamente associadas ao material solto do sauveiro em superficie, tanto na borda com no interior da área do bosque.

Da macrofauna de invertebrados, destaca-se três grupos mais importantes, observados macroscopicamente sendo : formigas saúvas, cupins e minhocas.

Formigas saúva (Tribu Atta) - A modificação mais significativa observada na superfície do solo no local é decorrente da atividade das formigas, tanto pela amplitude dos sauveiros como pelo volume de material remontado em superfície.

Foram enumerados 5 sauveiros ativos, distribuídos principalmente na linha de borda do bosque, com oleiro até cerca de $10 \mathrm{~m}$ além do limite do bosque, já em área de cultivo de cana-deaçucar. Corredores de ligação superficial são observados na superfície. Miklos (1992) destaca a espécie Atta sexdens rubropilosa (sauva limão) como colonizadora principal de uma floresta de eucaliptus. A atividade de transformação das saúvas sobre o solo se faz por dois mecanismos principais como: a) construção de montículos em superfície, constituídos por materiais acumulados trazidos dos horizontes inferiores do solo; b) construção de canais de comunicação entre as câmaras subterrâneas (postura de ovos, cultivo de fungos, lixeira). No que se refere ao comportamento alimentar das saúvas, destaca-se o aspecto simbiótico destes animais, que se alimentam de fungos mantidos em câmaras subterrâneas a partir do fornecimento contínuo de matéria orgânica da superficie, material seco ou verde ou mesmo restos de outros insetos, de acordo com a espécie.

No local do estudo foi observado transporte contínuo de material vegetal (seco e verde) para o interior do sauveiro. 
A superficie dos sauveiros, apresentam-se com cor bruno-avermelhado escuro (2,5 YR $3 / 5$ seca) com estrutura variando de granular grossa $(5 \mathrm{~mm}$ de diâmetro) à microagregada $(0,05$ a $2 \mathrm{~mm}$ de diâmetro). Estes agregados granulares são trazidos já prontos para a superfície, presos entre as mandíbulas dos animais, e são deixados soltos na saída das galerias, formando os cones de detritos. Quando umidecidos pela chuva, principalmente, estes agregados granulares desfazem-se na maior parte e, devido ao arranjo solto, são facilmente incorporados ao horizonte superficial do solo.

Minhocas - A ação direta deste grupo sobre o solo foi observada nos horizontes superficiais entre 0 a $40 \mathrm{~cm}$ pela ocorrência de minhocas quiescentes (no interior de câmaras ovoidais) e de coprólitos grumosos de até $5 \mathrm{~mm}$ de diâmetro e cilíndricos com $2 \mathrm{~mm}$ de diâmetro até $1 \mathrm{~cm}$ de comprimento dispersos no solo. As minhocas encontradas no perfil eram pequenas (até $2 \mathrm{~cm}$ de comprimento) e despigmentadas. Correspondem a tipos endogêicos, caracterizados por resistir a longo período de seca, vivendo permanentemente dentro do solo e se alimentando de matéria orgânica misturada ao solo, sendo relativamente pouco abundantes.

Cupins - Constatou-se presença de cupinzeiros abandonados, com a parte epígea parcialmente ou totalmente destruída e ocupados por formigas.

\subsection{Clima}

O clima na região (figura 3) apresenta-se sob um regime estacional irregular, com associação do regime pluviométrico entre os períodos de verão e inverno correspondendo aos períodos de maior e menor precipitação respectivamente. $O$ verão é quente, sem máximas diárias muito elevadas e com temperatura média de $25^{\circ} \mathrm{C}$. O período mais frio, de abril a setembro, apresenta temperatura média mínima diária de $17^{\circ} \mathrm{C}$ e precipitações média mensal de $50 \mathrm{~mm}$. A temperatura média anual varia entre 18 e $20^{\circ} \mathrm{C}$ e a pluviosidade média anual é de $1430 \mathrm{~mm}$ (Nimer, 1979; Nascimento et al., 1999). 


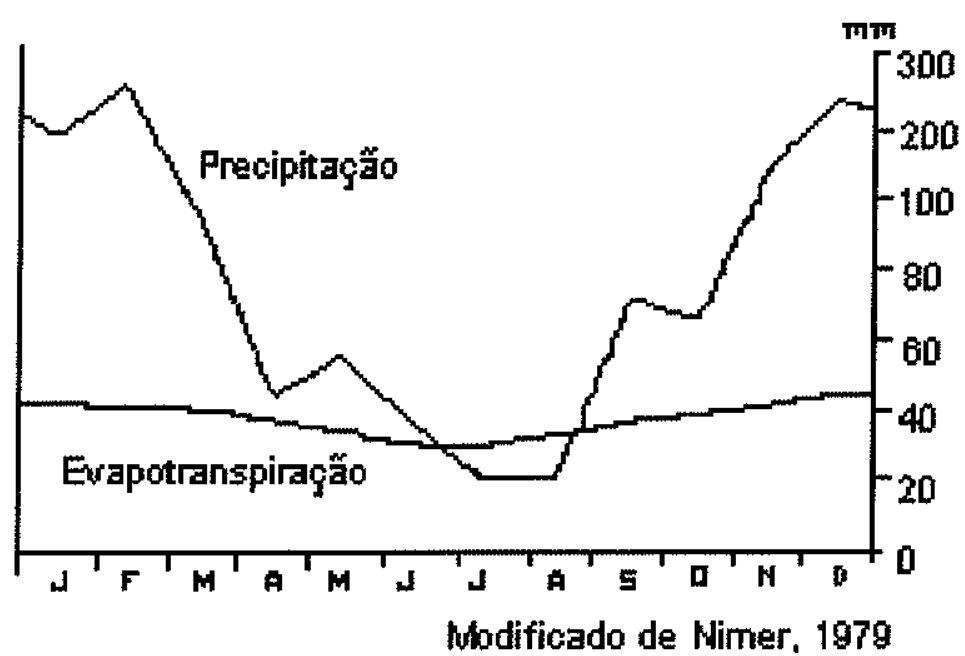

Figura 3: Precipitação e evapotranspiração em Piracicaba.

\section{METODOLOGIA}

Neste trabalho foram realizadas caracterizações de microagregados do perfil do Latossolo de Iracemápolis e de pelotas produzidas por cupins no campo e no laboratório (Figura 5).

\subsection{Descrição macromorfológica do solo, dos cupins e amostragens no campo}

Para o estudo do solo foi feito:

1) Abertura de uma trincheira de $1,5 \mathrm{~m}$ de comprimento $\times 1,5 \mathrm{~m}$ de largura $\times 2 \mathrm{~m}$ de profundidade.

2) Descrição macromorfológica do perfil (segundo Lemos \& Santos, 1996).

3) Amostragem dos horizontes diagnósticos do perfil seguintes profundidades: $0-35 \mathrm{~cm}$, $40-60 \mathrm{~cm}, 80-100 \mathrm{~cm}, 100-120 \mathrm{~cm}, 160-200 \mathrm{~cm}$ (amostras soltas). A amostra 100-120 cm (melhor representativa do horizonte latossólico $B_{L}$ foi selecionada para os experimentos com os cupins em laboratório). Também foram coletados monolitos indeformados de $10 \mathrm{~cm} \times 10 \mathrm{~cm} \times 10 \mathrm{~cm}$ (Lemos \& Santos, 1996) nas profundidades: 0-10cm, 40-50cm, 80-90cm, 110-120cm, 190$200 \mathrm{~cm}$. 
O estudo dos cupins, compreendeu:

1) Estudo e amostragem dos cupins - Para a amostragem de cupins, vários locais foram visitados para se obter espécies de cupins distintas, principalmente em relação a tamanho das peças bucais dos operários, visando-se avaliar se ocorre relação entre dimensão das mandíbulas e das pelotas produzidas. Ao mesmo tempo procurou-se obter espécies de ampla ocorrência.

Foram coletados dois gêneros distintos, Cornitermes e Syntermes amostrando-se a maior variedade morfológica encontrada no cupinzeiro, que compreendeu a coleta de indivíduos alados maduros, alados imaturos (ninfas), soldados adultos, operários adultos, jovens e estágios não pigmentados. Parte dos cupins foi fixado em álcool etílico à $70 \%$ e parte foi transportada viva para experimento no laboratório. Todos os cupins foram coletados nas galerias ou câmaras abaixo da superfície do solo. A descrição morfométrica dos soldados e operários seguiu a terminologia de Cancello (1997) e a identificação taxonômica segundo Constantino (1999).

2) Estudo e amostragem de pelotas de cupins - Foram coletadas pelotas no mesmo local onde foram amostrados os cupins. Para os cupins do gênero Cornitermes amostrou-se a superfície de um ninho epígeo localizado em Iracemápolis (figura 4a). Para os cuppins do gênero Syntermes, foi amostrada a superfície de um montículo terroso (figura 4b), em Ribeirão Preto, por não se encontrar na região de Iracemápolis.
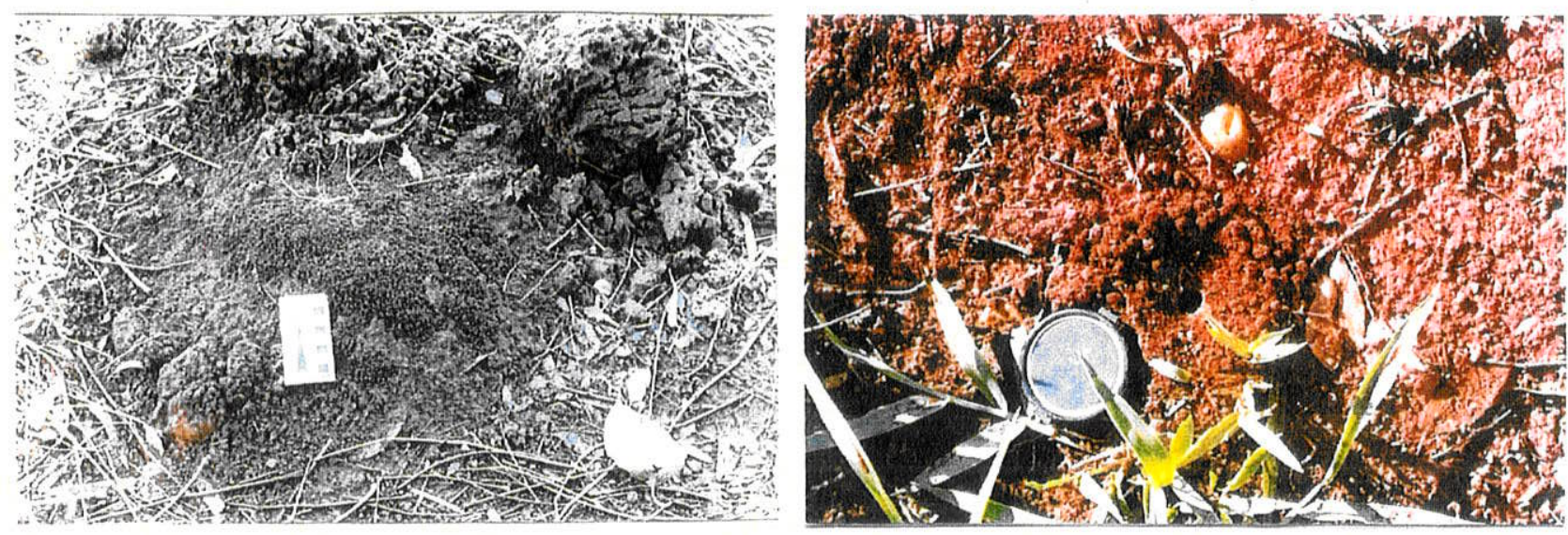

(a)

(b)

Figura 4: (a) Ninho de Cornitermes em reconstrução com pelotas abundantes na superficie.(Iracemápolis).(b) Detalhe de montículo subsidiário de Syntermes, localizado a cerca de $3 \mathrm{~m}$ do ninho principal (Ribeirão Preto). 


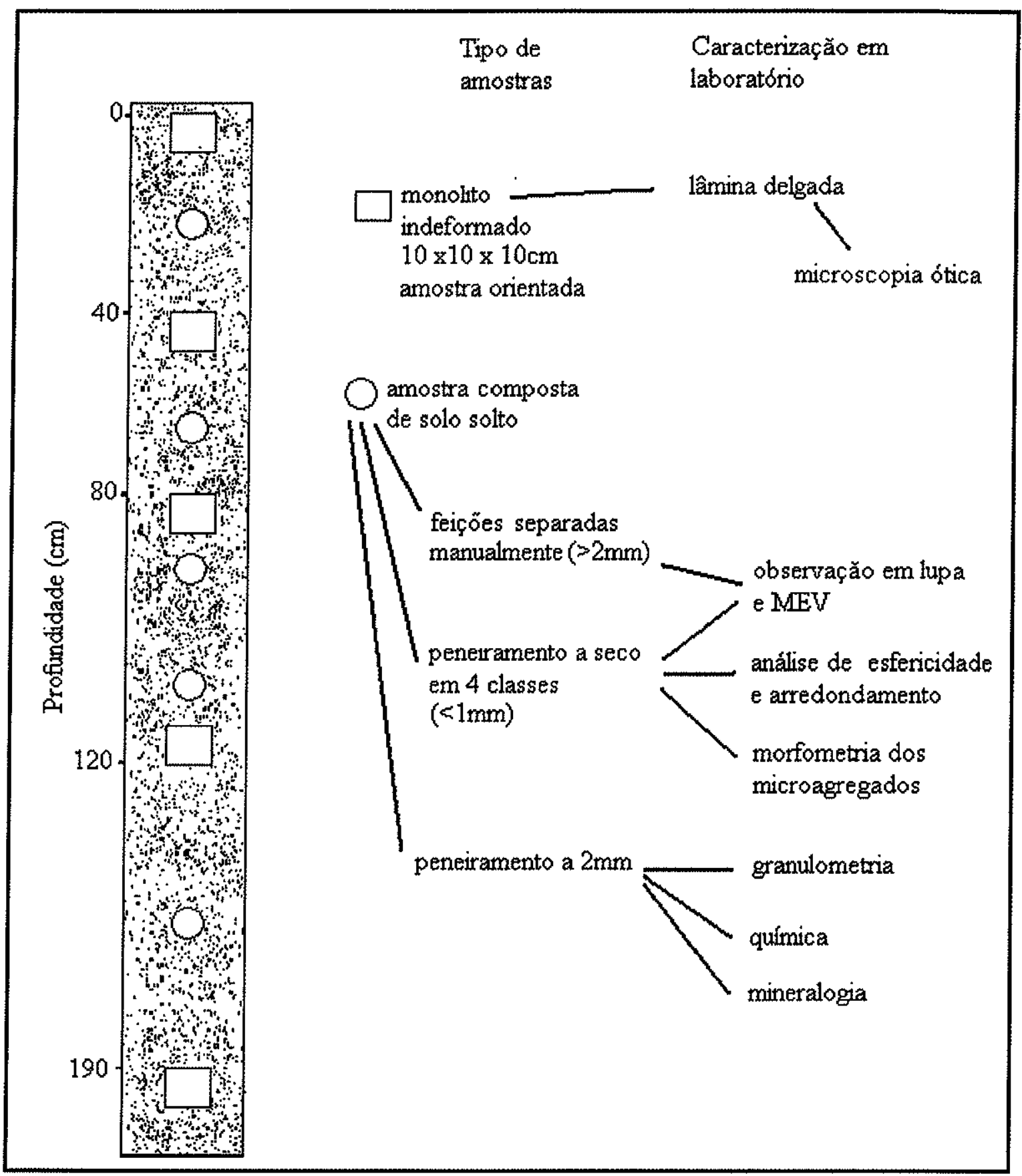

Figura 5: Esquema de amostragem em campo e das caracterizações no laboratório, empregados nos diferentes tipos de amostras do Latossolo. 


\subsection{Caracterização das amostras do Latossolo}

\subsubsection{Preparação das amostras}

A preparação das amostras do solo solto consistiu na separação manual de fragmentos vegetais (raizes, folhas) e feições pedológicas (concreções, canais, câmaras) com posterior secagem em estufa à $40^{\circ} \mathrm{C}$ por $24 \mathrm{~h}$, quarteamento manual e peneiramento a $2 \mathrm{~mm}$. Cerca de $200 \mathrm{~g}$ de cada profundidade foi encaminhada para caracterização química e granulométrica (figura 5).

\subsubsection{Observação em lupa binocular}

As feições (canais, câmaras e concreções) encontradas no perfil foram observadas em lupa binocular com ampliação de 10 a 50x.

\subsubsection{Micromorfologia}

Os monolitos indeformados coletados no campo, foram mantidos no laboratório durante 3 semanas para secagem ao ar livre. Foram impregnados com araldite e encaminhados para confecção de lâminas delgadas de $1,5 \mathrm{~cm} \times 2,5 \mathrm{~cm}$. A profundidade das amostras está assinalada na figura 5. A descrição micromorfológica seguiu metodologia de Brewer (1964) e Bullock et al., (1978).

\subsubsection{Microscopia eletrônica de varredura (MEV)}

Amostras de microagregados individualizados tiveram a superfície metalizada (vaporização com ouro). Utilizou-se um microscópio da marca GEOL, modelo KGM 5600 LV, acoplado à uma microsonda EDS de marca Noran, com um detector de fluoreto de Lítio. A observação foi conduzida utilizando-se a captação de elétrons secundários. A microsonda EDS permite realizar análise química qualitativa.

Os microagregados foram observados em ampliação crescente, com o intuito de reconhecer similaridades entre os tipos de microagregados, anteriormente identificados na observação em microscopia ótica. 


\subsubsection{Morfometria e estabilidade dos microagregados}

Amostras de $50 \mathrm{~g}$ foram peneiradas a seco e separadas em 4 classes: $<0,053 \mathrm{~mm} ; 0,053-$ 0,15mm; 0,15-1,0mm e >1,0mm (adaptado de Singh \& Singh, 1995). Para a observação dos microagregados utilizou-se microscópio ótico de marca Carl-Zeiss (modelo Stemi SV-6) em aumento de 30x a 50x. Cada amostra foi quarteada manualmente para homegenização e disposta em uma placa acrílica (de $10 \mathrm{~cm}$ de diâmetro) com o fundo revestido por papel de filtro umidecido. Desta forma os agregados se umidecem gradualmente atingindo seu estado turgido (Trapnell \& Webster, 1986). Uma característica decorrente do umidecimento é a fragmentação de alguns agregados, que segundo Trapnell \& Webster (1986), refletem diferenças de estabilidade. Foi determinada a dimensão de 50 microagregados segundo os três eixos A, B e C (figura 6) para cada uma das 4 classes granulométricas e para cada profundidade.

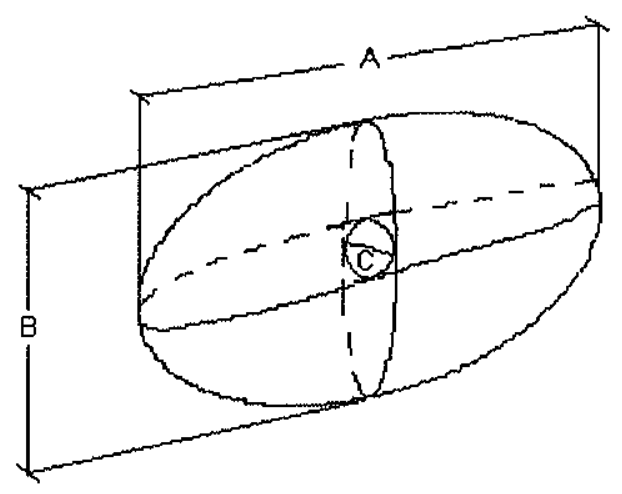

Figura 6: Eixos A, B, C medido para cada agregado.

A partir dos valores dos eixos $\mathrm{A}, \mathrm{B}$ e $\mathrm{C}$ foram determinadas as razões $\mathrm{B} / \mathrm{A}$ e $\mathrm{C} / \mathrm{B}$ (Figura 7), para classificação dos microagregados, segundo a classificação de Zingg (1935), que propõe quatro formas principais (Tabela 1).

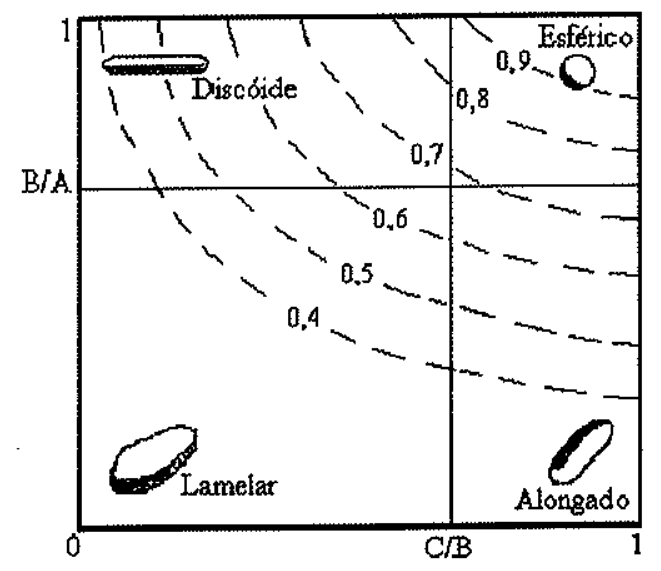

Figura 7: Diagrama de Zinng, com curvas de igual esfericidade de Krumbein (Willians, 1965). 
Tabela 1: Forma de microagregados a partir das razões B/A e C/B (Zingg, 1935).

\begin{tabular}{|c|c|l|}
\hline $\mathbf{B} / \mathbf{A}$ & $\mathbf{C} / \mathbf{B}$ & \multicolumn{1}{|c|}{ Forma } \\
\hline$>2 / 3$ & $<2 / 3$ & Discóide \\
\hline$>2 / 3$ & $>2 / 3$ & Esferoidal \\
\hline$<2 / 3$ & $<2 / 3$ & Lamelar \\
\hline$<2 / 3$ & $>2 / 3$ & Alongada \\
\hline
\end{tabular}

Depois da medida morfométrica de cada microagregado realizou-se também a medida do grau arredondamento (Müller, 1967) e de esfericidade por comparação visual (Rittenhouse, 1943). Finalmente foi avaliada a estabilidade observando os microagregados durante saturação hídrica saturada com imersão em água pura (Trapnell \& Webster, 1986) e imersão em solução de hidróxido de sódio (Edwards \& Bremner, 1967).

\subsubsection{Densidade}

A densidade aparente foi medida pelo método do anel volumétrico (Lemos \& Santos, 1996) e a densidade real pelo método do picnômetro (Suguio, 1973).

\subsubsection{Granulometria}

A análise granulométrica pelo método do densímetro (Kiehl, 1979), quantificou as frações areia, silte e argila. Utilizou-se como dispersante solução de hexametafosfato de sódio e hidróxido de sódio a $0,1 \mathrm{~N}$.

A análise granulométrica à laser teve como objetivo a análise da distribuição do tamanho dos agregados. $\mathrm{O}$ método consiste em estabelecer o tamanho das partículas e a frequência das populações correspondentes. Utilizando a difração ótica de raio laser, o método baseia-se sobre o princípio que, partículas de diferentes diâmetros apresentam difrações específicas num ângulo determinado. Um feixe de raio laser monocromático incide e atravessa uma suspensão líquida. $O$ feixe difratado é captado por 32 anéis detectores concêntricos, cada um recuperando uma parte da luz difratada. As lentes que focam o raio difratado são escolhidas em função da distribuição granulométrica estimada pelo peneiramento prévio (Chapell, 1998; Muggler et al, 1997). Utilizou-se aparelho da marca Malvern, modelo-SB com lente de $300 \mathrm{~mm}$, com água deionizada e sem tratamento dispersante das amostras. 


\subsubsection{Caracterização química}

A dosagen de $\mathrm{SiO}_{2}, \mathrm{Al}_{2} \mathrm{O}_{3}, \mathrm{Fe}_{2} \mathrm{O}_{3}, \mathrm{TiO}_{2}, \mathrm{MnO}_{2}$ foi realizada após ataque sulfúrico. Os elementos $\mathrm{P}, \mathrm{K}, \mathrm{Ca}, \mathrm{Na}$ e $\mathrm{Mg}$ (trocáveis) foram dosados por extração com resina trocadora de íons e o íon $\mathrm{Al}^{3+}$ por extração pelo $\mathrm{KCL}$ a $1 \mathrm{~N}$. O carbono orgânico foi determinado pelo método Walkley-Black. A determinação de Carbono total foi realizada em autoanalisador LECO CN2000 do Laboratório de Biogeoquímica do solo com cerca de $2 \mathrm{~g}$ de solo fracionado a $100 \mu \mathrm{m}$.

\subsubsection{Caracterização mineralógica}

As amostras para análise mineralógica foram inicialmente deferruginizadas (com ditionito de sódio em extrato sulfúrico) e a fração argila foi separada por sedimentação em água e ultracentrifugação sucessiva do sobrenadante. A seguir as amostras foram pulverizadas em cadinho e pistilo de ágata, preparando-se lâminas orientadas com tratamentos de glicolagem, aquecimento, saturação catiônica. (Brindley \& Brown, 1984). A análise difratométrica foi realizada com um difratômetro Philipps 3710, equipado com tubo de cobre e um detector proporcional (radiação $\mathrm{Cu} \mathrm{K \alpha}$; tensão de $40 \mathrm{Kv}$ e corrente de $40 \mathrm{~mA}$ ). Os picos foram tabelados e tratados segundo software DRX-APD para a determinação de minerais.

\subsection{Caracterização das pelotas do campo e do laboratório}

\subsubsection{Experimentos com os cupins no laboratório}

Os cupins utilizados no experimento, foram introduzidos nos terrários (ítem 4.3.2) cerca de $2 \mathrm{~h}$ após a coleta no campo e foi utilizado mesmo número e mesmo tipo de indivíduos para cada um dos cinco terrários. Assim, em cada terrário foram inseridos 60 operários adultos e dez soldados adultos.

No terrário $\mathrm{T} 1$ foi colocada amostra de Latossolo desagregado (ítem 4.3.3), no terrário T2, amostra de Latossolo peneirado e no terrário T3, amostra de argila cinza, com cupins Cornitermes nos três casos. No terrário T4 foi colocada amostra de Latossolo peneirado com cupins Syntermes.

Cerca de uma hora após introdução nos terrários, os cupins começaram a atividade escavadora e a produção das pelotas.

As condições ambientais foram mantidas constantes para os quatro terrários: Com luz artificial fluorescente por um período de $8 \mathrm{~h}$ e sem luz no período restante, com temperatura 
ambiente média na superficie do terrário de $24,5^{\circ} \mathrm{C}$, com umidade, próxima ao ponto de saturação. A sobrevida dos cupins foi de duas semanas sendo que os soldados apresentaram sobrevida menor, uma semana e meia.

Aspectos de detalhe sobre a atividade construtora dos cupins em laboratório foram apresentadas em Graminha \& Melfi (2000).

A argila cinza do terrário T3 foi comprada no comércio com o objetivo de avaliar pelotas produzidas em material com pouco ou ausente em óxidos de ferro.

\subsubsection{Montagem dos terrários}

Os terrários (figura 8) foram montados em vidro liso transparente de $5 \mathrm{~mm}$ de espessura, com dimensão de $25 \times 13 \times 15 \mathrm{~cm}$ e preenchidos com solo desagregado em $2 / 3$ do volume total. Uma abertura de $1 \mathrm{~cm}$ na base de cada do terrário propiciou o fluxo ascendente da água colocada do lado de fora em uma bandeja plástica. Como revestimento de fundo dos terrários foi colocado uma tela plástica cobrindo-se as aberturas laterais para evitar o escape de solo e a saída de cupins. A umidade uniforme do solo representa um parâmetro fundamental para sobrevivência e para possibilitar a moldagem das pelotas pelos cupins.

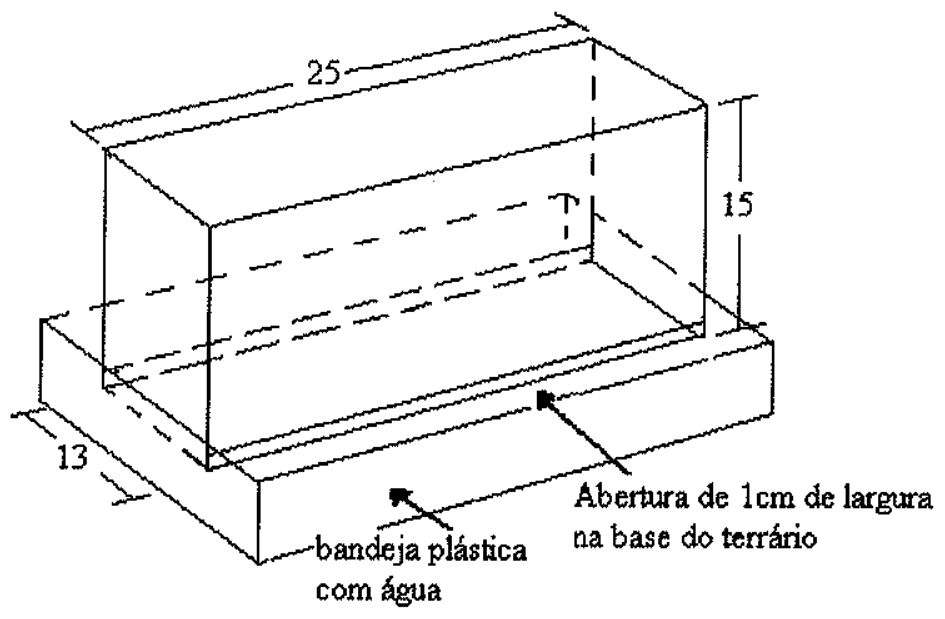

Figura 8: Ilustração do terrário de vidro utilizado nos experimentos no laboratório.

\subsubsection{Desagregação mecânica dos microagregados}

Para a desagregação dos microagregados utilizou-se cerca de $10 \mathrm{~kg}$ de solo solto da profundidade de $100-120 \mathrm{~cm}$ do perfil de Iracemápolis para prencher os terrários. Os seguintes ensaios foram realizados: 
1) Quebra manual em almofariz cerâmico com pistilo de borracha (ensaios com solo seco e úmido).

2) Moinho rotativo com esferas de borracha em solo seco.

3) Energia ultra-sônica utilizada em gerador Thornton-IMPEC $220 \mathrm{~V}$ (em potência constante 240W a tempos variados) (Levi et al., 1993).

4) Trituração em liquidificador (Figura 9).

A eficiência da desagregação foi avaliada visualmente em lupa por comparação com uma escala de frequência de microagregados (Figura 10). $O$ procedimento que se mostrou mais eficiente para desagregar foi a trituração um liquidificador.

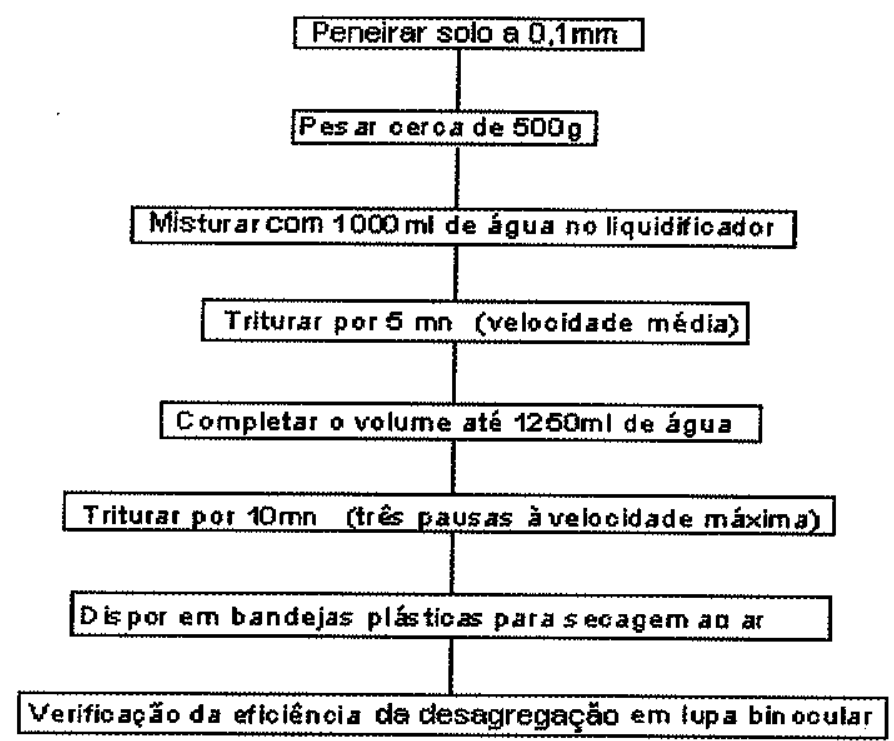

Figura 9: Protocolo utilizado para a desagregação mecânica por trituração com liquidificador.

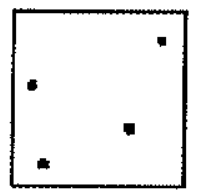

$99 \%$

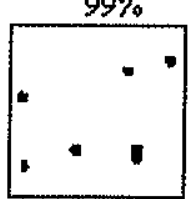

$98 \%$

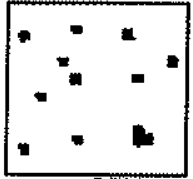

$97 \%$

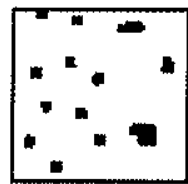

$95 \%$

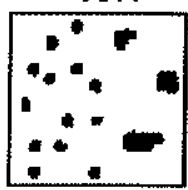

$93 \%$

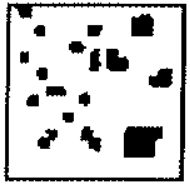

$90 \%$

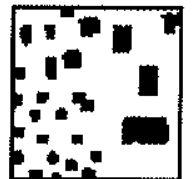

$85 \%$

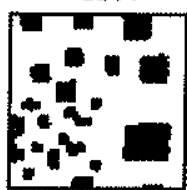

$80 \%$

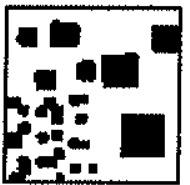

$75 \%$

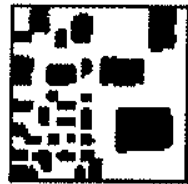

$70 \%$

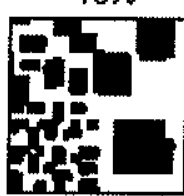

$60 \%$

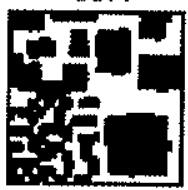

- os pontos escuros

cottespondetm a microagregados

Figura 10: Quadro de frequência de microagregados (modificado de Lemos \& Santos, 1996). 
4.3.4 Morfologia das pelotas em lupa binocular e em microscópio eletrônico de varredura (MEV)

As pelotas dos cupins foram coletadas no campo com uso de um pincel macio e acondicionadas em tubos de vidro. Todo o procedimento em lupa binocular (ítem 4.2.2) e observação no MEV utilizado para as amostras do Latossolo (ítem 4.2.4) foi igualmente aplicado para a observação das pelotas dos cupins.

\subsubsection{Caracterização granulométrica, química e mineralógica das pelotas}

Foram realizadas análise granulométrica por raio laser (ítem 4.2.7), dosagem de Carbono e Nitrogênio (ítem 4.2.8) e mineralogia por difração de raio $\mathrm{x}$ (ítem 4.2.9), seguindo-se procedimento semelhante utilizado para as amostras do Latossolo.

A análise por granulometria a laser foi realizadas para as duas amostras do campo de pelotas dos cupins Cornitermes e Syntermes. 


\section{RESULTADOS}

\subsection{Descrição macromorfológica do perfil}

Horizonte A (0 a $37 \mathrm{~cm})$, bruno-avermelhado escuro (2,5YR 2,5/3 úmido), brunoavermelhado escuro (2,5YR 3/4 seco); textura argilosa; $70 \%$ de estrutura granular de diâmetro médio de $0,5 \mathrm{~cm}$ de diâmetro e $30 \%$ de subestrutura microgranular maciça (diâmetro inferior a $1 \mathrm{~mm})$; raízes abundantes $\left(5 / \mathrm{cm}^{2}\right)$ de 0,5 a $2 \mathrm{~cm}$ de diâmetro; coprólitos cilindrícos de $3 \mathrm{~mm}$ de diâmetro, câmaras ovoidais $(2 \times 1 \mathrm{~cm})$ horizontais; serapilheira de $5 \mathrm{~cm}$; porosidade intergranular de 1 a $5 \mathrm{~mm}$ de diâmetro; limite inferior ondulado de $3 \mathrm{~cm}$ (variação de estrutura).

Horizonte B $(37$ a $65 \mathrm{~cm})$, bruno-avermelhado escuro (2,5YR $3 / 3$ úmido), brunoavermelhado escuro $(2,5 \mathrm{YR} 3 / 5 \mathrm{seco})$; textura argilosa; $70 \%$ com estrutura maciça microgranular (de diâmetro inferior a $1 \mathrm{~mm}$ ) e $30 \%$ com estrutura granular de diâmetro médio de $0,5 \mathrm{~mm}$; raízes $\left(<3 / \mathrm{cm}^{2}\right)$ de diâmetro inferior a $1 \mathrm{~mm}$; canal de $2 \mathrm{~cm}$ de diâmetro completamente preenchido por microagregados soltos; câmara ovoidal $(3 \times 5 \mathrm{~cm})$ incompletamente preenchida por microagregados soltos; porosidade intergranular (1 a $5 \mathrm{~mm}$ de diâmetro); limite inferior progressivo de $10 \mathrm{~cm}$ (variação de cor).

Horizonte BC ( 65 a $220 \mathrm{~cm}$ ), bruno-avermelhado escuro (2,5YR 2,5/3,5 úmido), vermelho escuro (10R $3 / 5$ seca); textura argilosa; estrutura maciça microgranular de diâmetro $<1 \mathrm{~mm}$; poucas raízes $\left(<1 / \mathrm{cm}^{2}\right)$, de diâmetro menor que $1 \mathrm{~mm}$; canal de $2 \mathrm{~cm}$ de diâmetro completamente preenchidos por microagregados soltos de diâmetro $<1 \mathrm{~mm}$; forte porosidade intergranular $(1 \mathrm{~mm}$ de diâmetro); litorelíquias de siltito arenoso com borda amarela de $1 \mathrm{~mm}$ de espessura ou de diabásio de $3 \mathrm{~cm}$ de diâmetro, subangulosos.

Da superficie até $100 \mathrm{~cm}$ de profundidade ocorrem várias feições (figura 11) indicativas da atividade biológica, principalmente de cupins, formigas e minhocas.

- Câmaras esferoidais inferior ou igual a 1,5cm de diâmetro com revestimento de parede de $1 \mathrm{~mm}$ de espessura e com superfície lisa; presença de minhocas vivas ocupando as câmaras até $45 \mathrm{~cm}$ de profundidade;

- Câmaras de diâmetro igual ou superior a $10 \mathrm{~cm}$, de forma irregular, sem revestimento de parede; presença de formigas (principalmente Atta) ativas nas câmaras até $50 \mathrm{~cm}$ de profundidade; 
- Canais e câmaras ovoidais com diâmetro igual ou inferior a $3 \mathrm{~cm}$ com revestimento de parede de $1 \mathrm{~mm}$ de espessura, provavelmente em relação à ocupação remanescente de cupins;

- Feições particulares foram observadas como coprólitos de minhocas de 0,5 a $1 \mathrm{~mm}$ de diâmetro, abundantes pincipalmente entre 0 a $45 \mathrm{~cm}$ de profundidade. Também foram identificados fragmentos de carvão, nódulos ferruginosos e litorelíquias (encontradas a partir de $150 \mathrm{~cm}$ de profundidade).

\subsection{Observação das feições em lupa binocular}

A observação por lupa binocular revelou a presença de volumes maciços (figura 12: A e B) com marcas circulares ou alongadas (figura 12: E, F) interpretadas como marcas de remoção de argila pelo aparelho bucal e pelas mandíbulas dos cupins. A observação dos volumes maciços, mostrou também que ocorrem volumes que são constituídos por microagregados compactados (figura12: C, D).

$\mathrm{Na}$ figura 13 são apresentados fragmentos de canais de cupins com ou sem preenchimento por microagregados (figura 13: A, C, D).

Em conclusão, a abundância e a variabilidade das feições confirmam uma forte turbação e homogeneização biológica neste solo, mas não foi possível estabelecer qualquer ordem de importância ou cronologia entre a atividade específicas de cada espécie. 


\section{Principais feições macroscópicas (\$ l mm)}

Ch Raizes finas ( $1 \mathrm{~mm})$, dispersas (1 a $\left.3 / \mathrm{cm}^{2}\right)$, verticais a inclinadas

D. Canal de 0,5 a $1,5 \mathrm{~cm}$ de diâmetro. com preenchimento parcial ou completo por microagregados, de seção longitudinal retilinea, subvertical a inclinada, sem ramificação. Pode apresentar parede com revestimentc de $1 \mathrm{~mm}$ de espessura

\%) Canal sem preenchimento, de 4 a $3 \mathrm{~mm}$ ce diâmetro, subvertical a inclinada, sem ramificaçẫo. Pode apresentar parede com revestimento de $1 \mathrm{~mm}$ de espessura

Câmara de 1,5 a 2,5cm de diâmetro com preenchimento parcial a completo por microagregadjs soltos, parede sem revestimento

Câmara sem preenchimento, de 1,5 a 2,5cm de diâmetro e parede sem revestimento

- Fragmentos de carvão

$\because$ Volumes maciços

$\Delta$ Litorelíquias (fragnentos de diabásio, siltito arenoso)

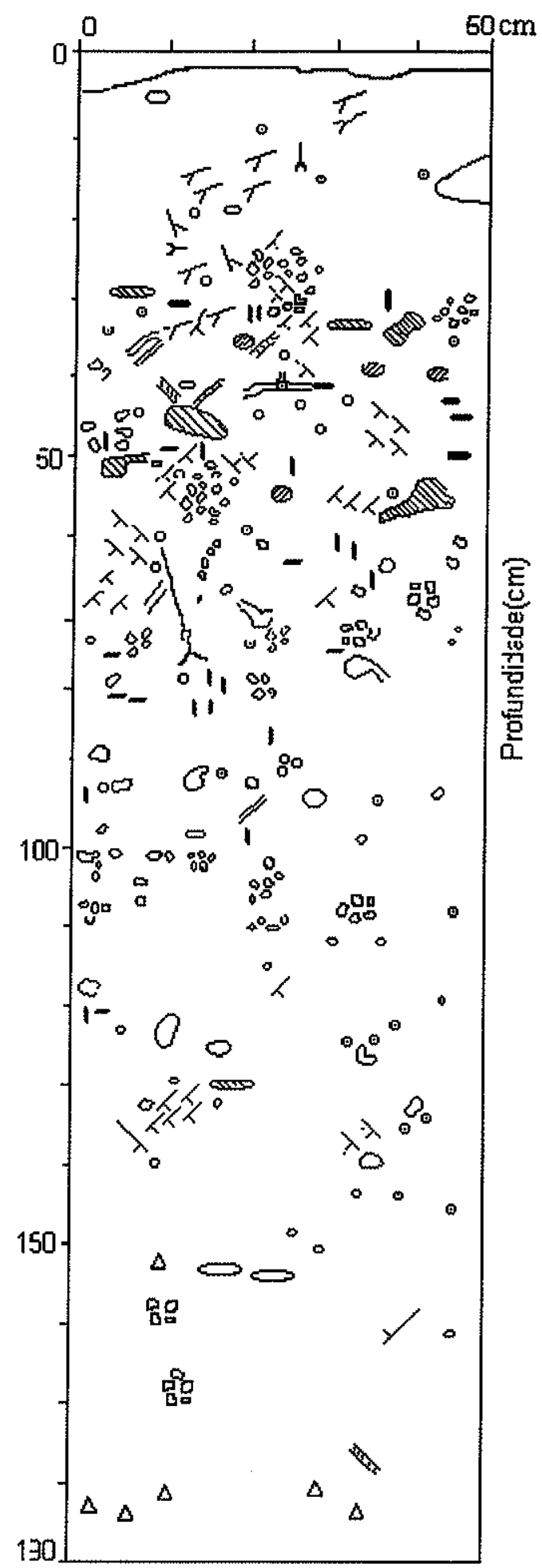

Figura 11: Feições observadas in situ no perfil do Latossolo. 


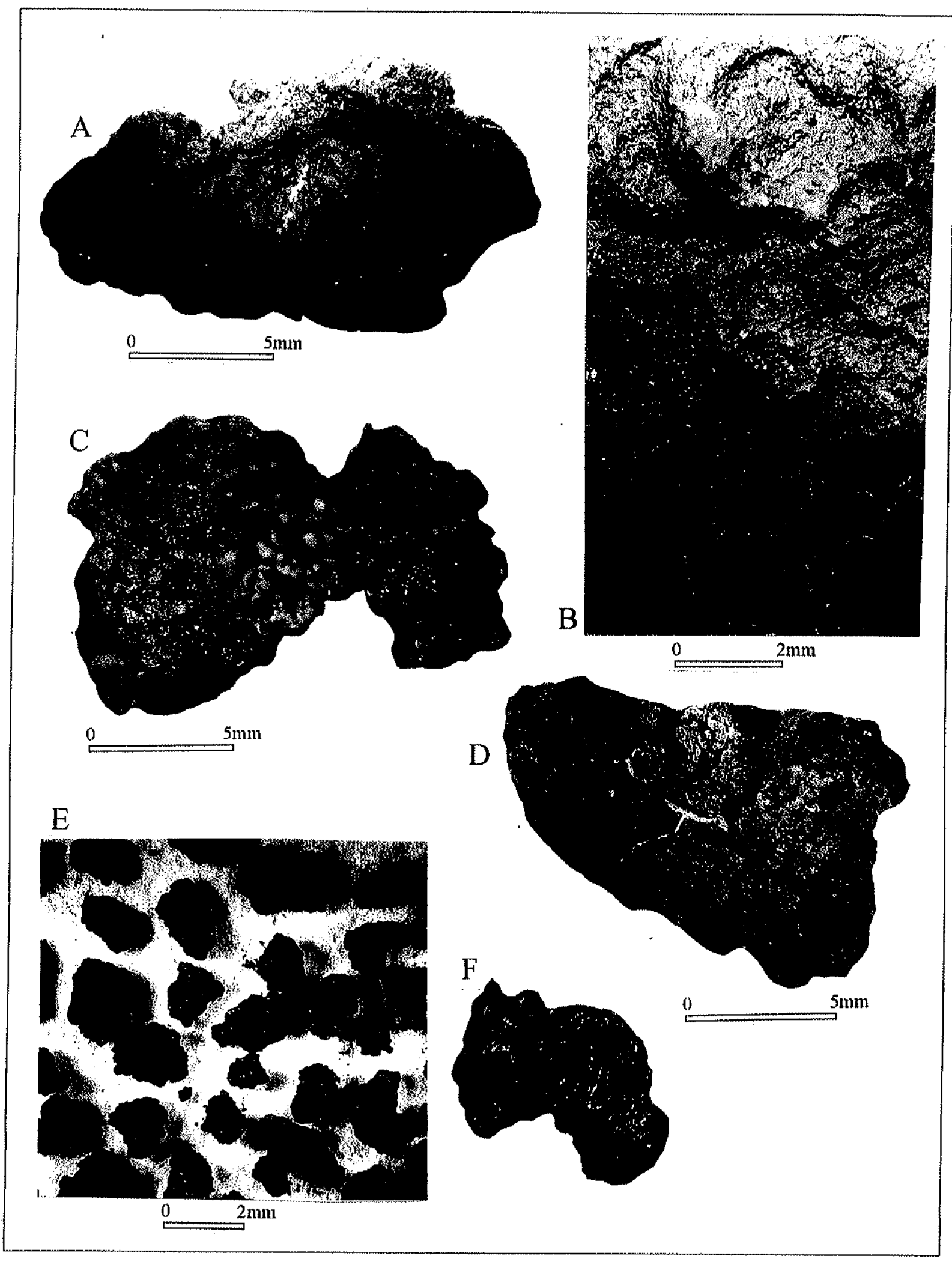

Figura 12: Feições observadas nas amostras do Latossolo (Lupa binocular, luz incidente) (lupa binocular, aumento de 50x).

(A) Volume maciço, apresentando marcas subcirculares côncavas, interpretadas como resultante da atividade de cupins (B) Detalhe das marcas da imagem A (C) e (D) Volumes aparecendo maciço na observação macroscópica e apresentado composto por microagregados compactados E) Volumes maciços mostrando estrias alongadas $(0,8 \mathrm{~mm}$ de comprimento) interpretadas com marcas de mandíbulas de cupins F) Detalhe do E. 


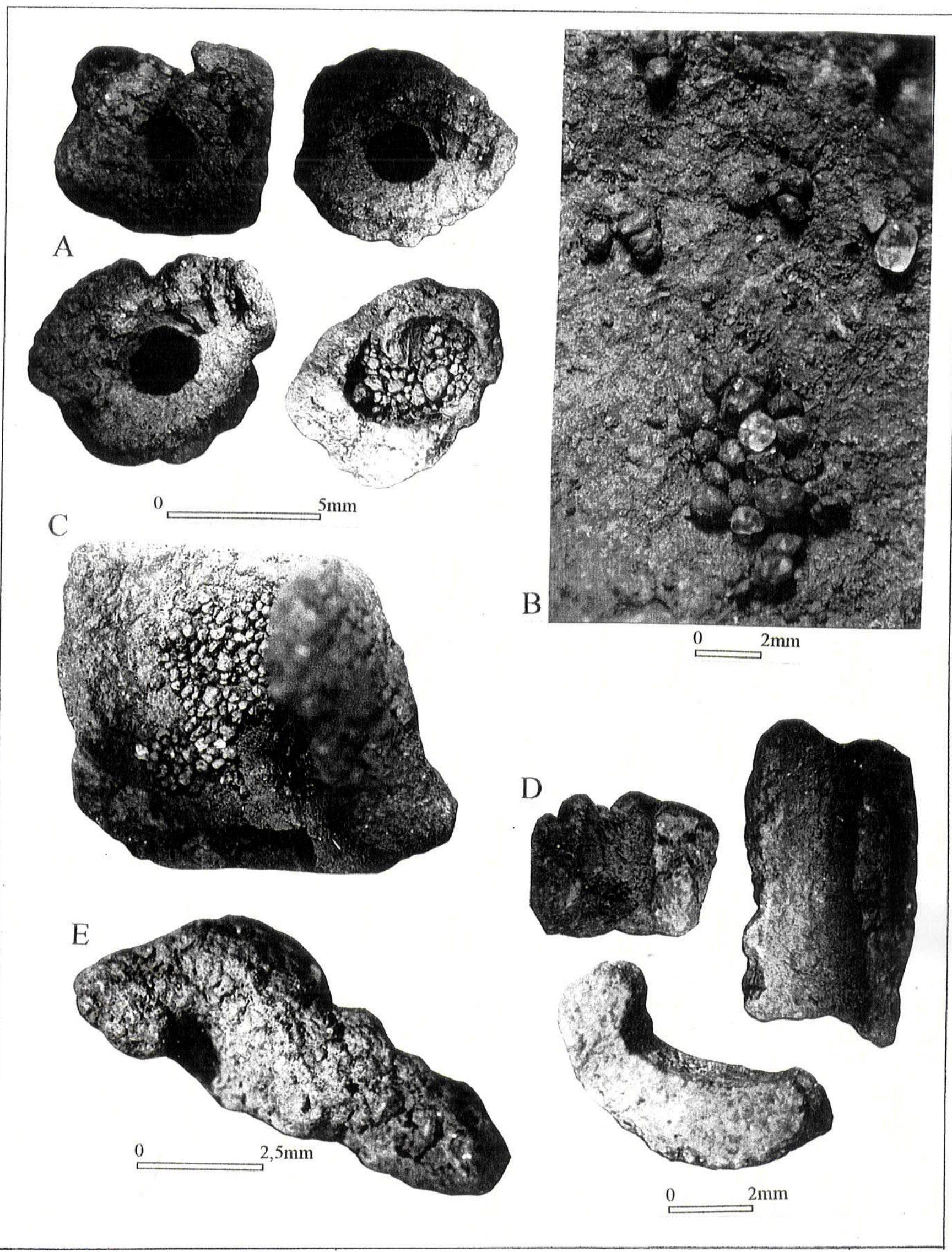

Figura 13: Feições observadas nas amostras do Latossolo (Lupa binocular, luz incidente) (lupa binocular, aumento de 50x).

(A) Seções transversais de canal, circulares a subcircular, com ou sem preenchimento por microagregados de diâmetro inferior a $1 \mathrm{~mm}$ e revestimento de parede de 1 a $2 \mathrm{~mm}$ de espessura (B) Detalhe dos microagregados do preenchimento de um canal, acompanhados de alguns grãos de quartzo (C) Seções longitudinal de um canal de $6 \mathrm{~mm}$ de diâmetro e revestimento de parede de $1 \mathrm{~mm}$. Microagregados agrupados na superfície da parede (D) Seções longitudinais de canal sem preenchimento (E) Molde interno de um canal, de 1,5 a $3 \mathrm{~mm}$ de diâmetro, formado por microagregados coalescentes. 


\subsection{Caracterização micromorfológica do Latossolo}

Para todas as profundidades $(0-10 \mathrm{~cm}, 40-50 \mathrm{~cm}, 80-90 \mathrm{~cm}, 110-120 \mathrm{~cm}, 190-200 \mathrm{~cm})$ predominou microestrutura complexa, onde é possível distinguir dois tipos principais: (i) microgranular com microagregados solto, subangulares a arredondados e (ii) microestrutura maciça com microagregados coalescentes. Nas profundidades de 110 a $120 \mathrm{~cm}$ (figura $16 \mathrm{~A}$ ) e de 190 a $200 \mathrm{~cm}$ (Figura 16D) observou-se também a ocorrência de duas populações de microagregados, sendo uma diâmetro de 100 a $200 \mu \mathrm{m}$ e outra com diâmetro de 20 a $50 \mu \mathrm{m}$ (figura 14D ).

A distribuição relativa (plasma-esqueleto) para todas as profundidade, é do tipo enaúlica ou porfirica aberta (Figura 14A), com plasma, bruno-vermelho a bruno-vermelho escuro, sob luz normal e isótico sob luz polarizada.

$O$ esqueleto é homogêneo e distribuído de maneira aleatória composto de quartzo (diâmetro entre 50 a $300 \mu \mathrm{m}$ ) e de minerais pesados, sem triagem granulométrica interna aos microagregados (figura 15C).

Observou-se zonas com microagregação bem desenvolvida (Figura 15D) e zonas de coalescência de microagregados (figuras 14C, 16A).

Áreas de coalescência de microagregados (figuras 14C, 15A) apresentam porosidade desenvolvida forte, intergranular, interconectada e fissuras pouco abundantes, presentes no limite de coalescência entre os microagregados (Figura 14C). As feições de perda de óxido de ferro, difusas, amarelas, estão sempre associadas aos poros em todo o perfil (figuras $14 \mathrm{C}, 15 \mathrm{~A}$ e D, $16 \mathrm{~A}$ e D).

Eswaran (1978) utiliza o termo aglutinic para o arranjo fortemente coalescente de microagregados (figura 17). Eschenbrenner (1986) demonstra que esta coalescência pode resultar da atividade de cupins. Também pode ser considerada como uma origem dos microagregados, a fissuração de um fundo matricial denso porfírico. Foram observadas áreas milimétricas fragmentadas em unidades menores formando microagregados subangulosos a arredondados (Figuras 14D, 15B, 16B). Assim a origem dos microagregados poderia ser o resultado da fissuração do fundo matricial denso porfírico.

Em relação com a porosidade observa-se um forte desenvolvimento de porosidade intergranular geralmente bem interconectada e associada à feições de perda de óxidos de ferro, difusa (marcada pela borda amarela dos poros). 

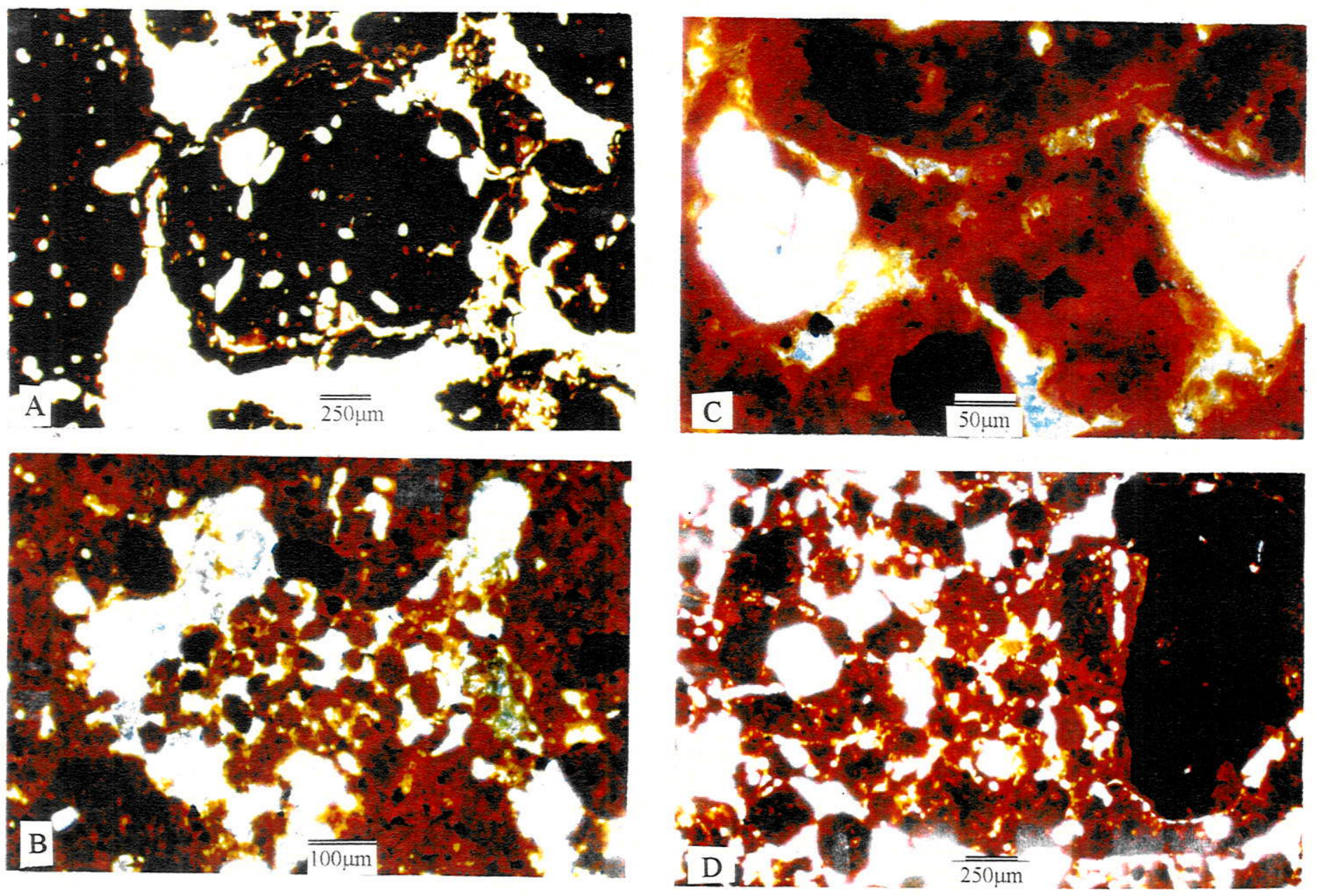

Figura 14: Microscopia ótica. (A) a (D) profundidade 0 - 10cm. (A) Área porfírica no centro da imagem. (B) Canal com preenchimento parcial por microagregados soltos, porosidade intergranular forte e pouco interconectada. (C) Detalhe de uma área porfírica onde distingue-se uma porosidade de arranjo compacto dos microagregados. Em amarelo nota-se feições de perda de óxidos de ferro na borda dos poros. (D) Área porfírica em curso de fragmentação, com individualização de microagregados subangulosos a arredondados. De (A) a (D) luz normal 

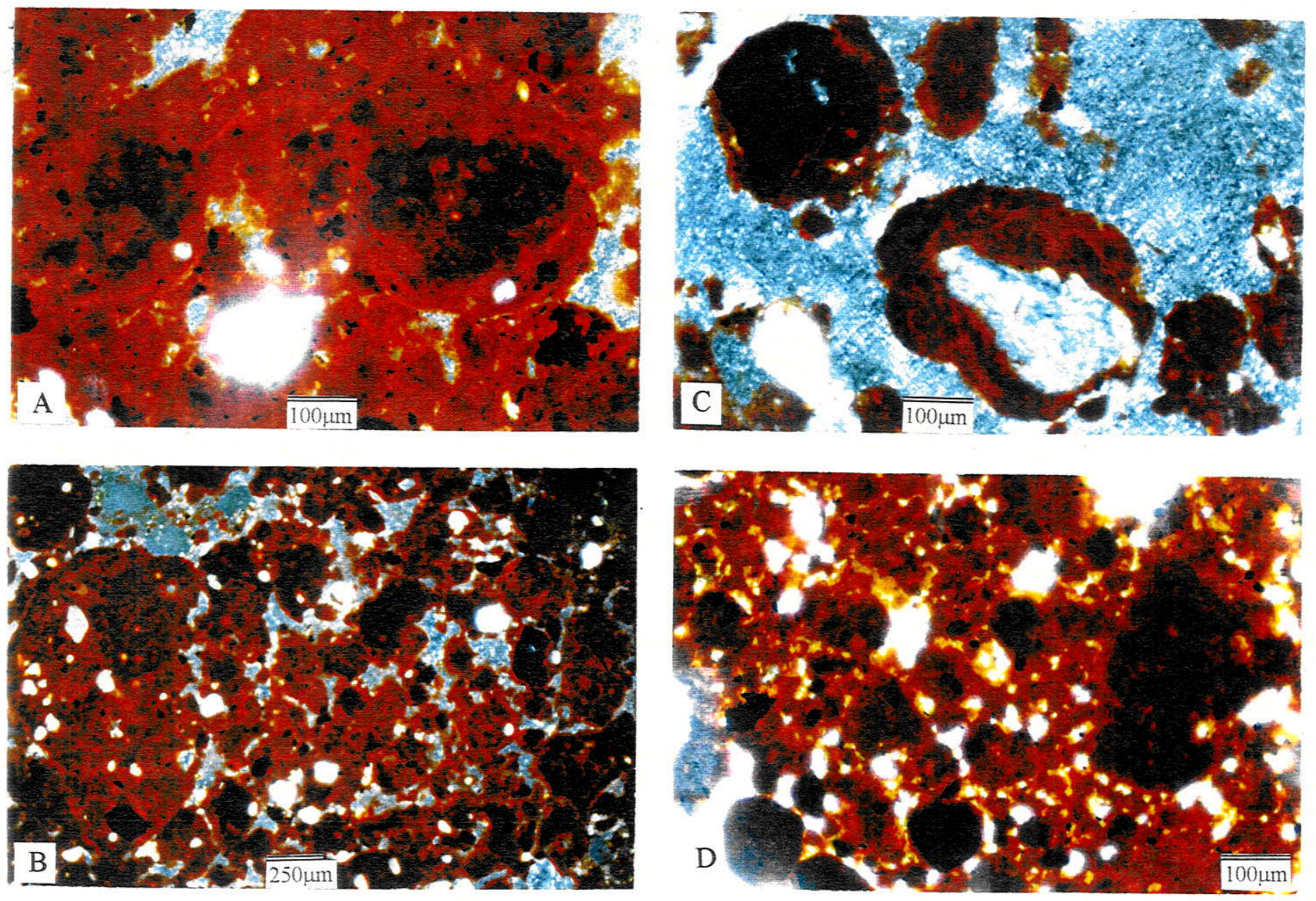

Figura 15: Microscopia ótica. (A) e (B), profundidade $40-50 \mathrm{~cm}$. (A) Coalescência de microagregados arredondados e porosidade intergranular pouco interconectada. (B) Volume maciço desestruturado internamente preservando os limites, formando microagregados subangulosos arredondados (C) e (D), profundidade 80 a $90 \mathrm{~cm}$. (C) Microagregados incluindo grãos de quartzo (à direita) incluindo grão de opaco (à esquerda) envolto por cobertura de plasma argiloso. (D) Presença de duas populações de microagregados com porosidade intergranular pouco desenvolvida. 

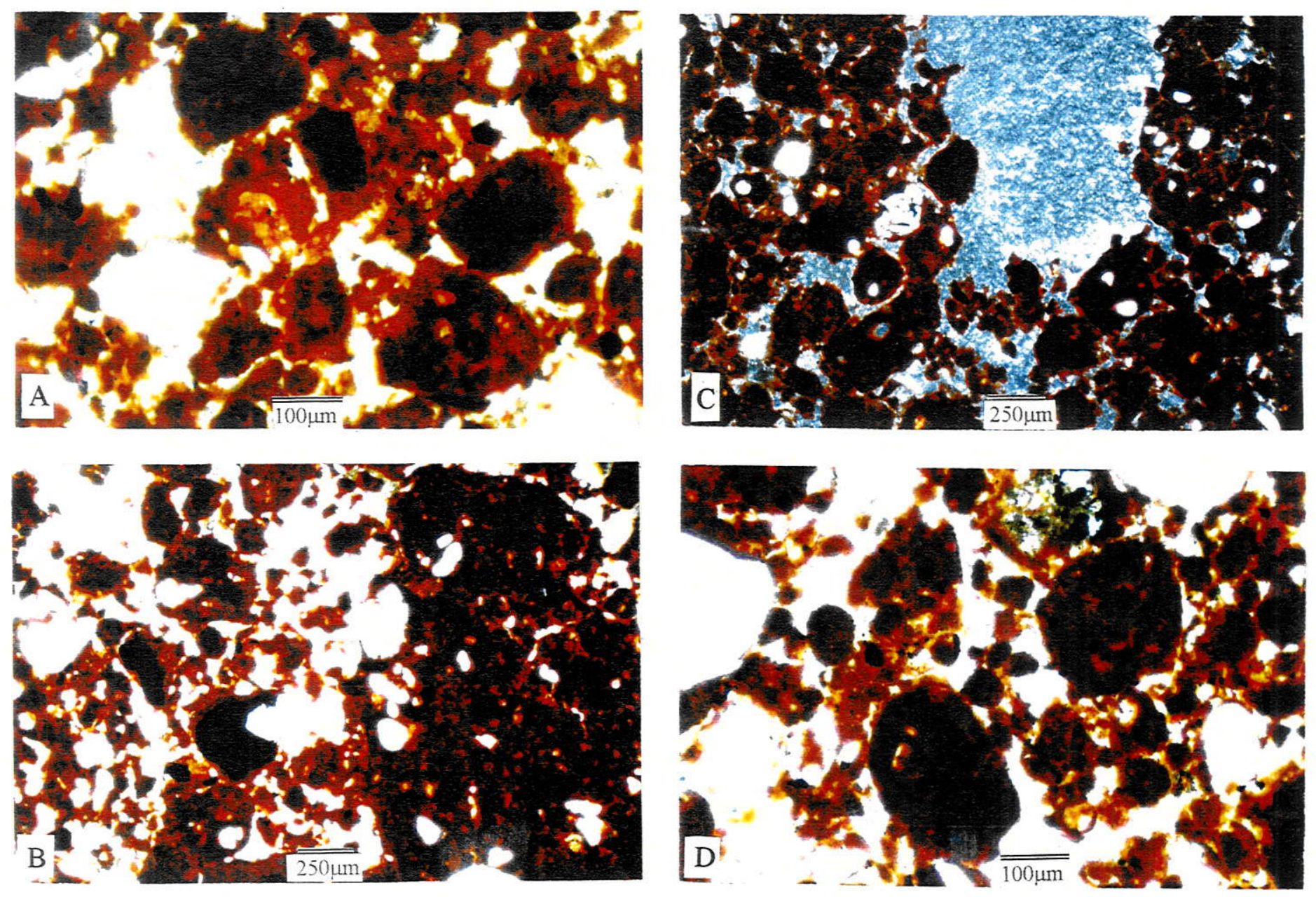

Figura 16: Microscopia ótica. (A), (B) e (C) profundidade 110-120cm. (A) Microagregados de 100 a $200 \mu$ m de diâmetro, arredondados a subangulosos, porosidade interagranular pouco conectada. (B) Transição-de um fundo matricial contínuo (à direita) para um fundo matricial microagregado. (C) Canal sem preenchimento por microagregados em contato direto com o fundo microagregado e porosidade interagregado bem desenvolvida e pouco conectada.(D) profundidade $190-200 \mathrm{~cm}$. Duas populações de microagregados, de 100 a $300 \mu \mathrm{m}$ de diâmetro e de 20 a $50 \mu \mathrm{m}$ de diâmetro, circulares a ovoidais, bem arredondados. 

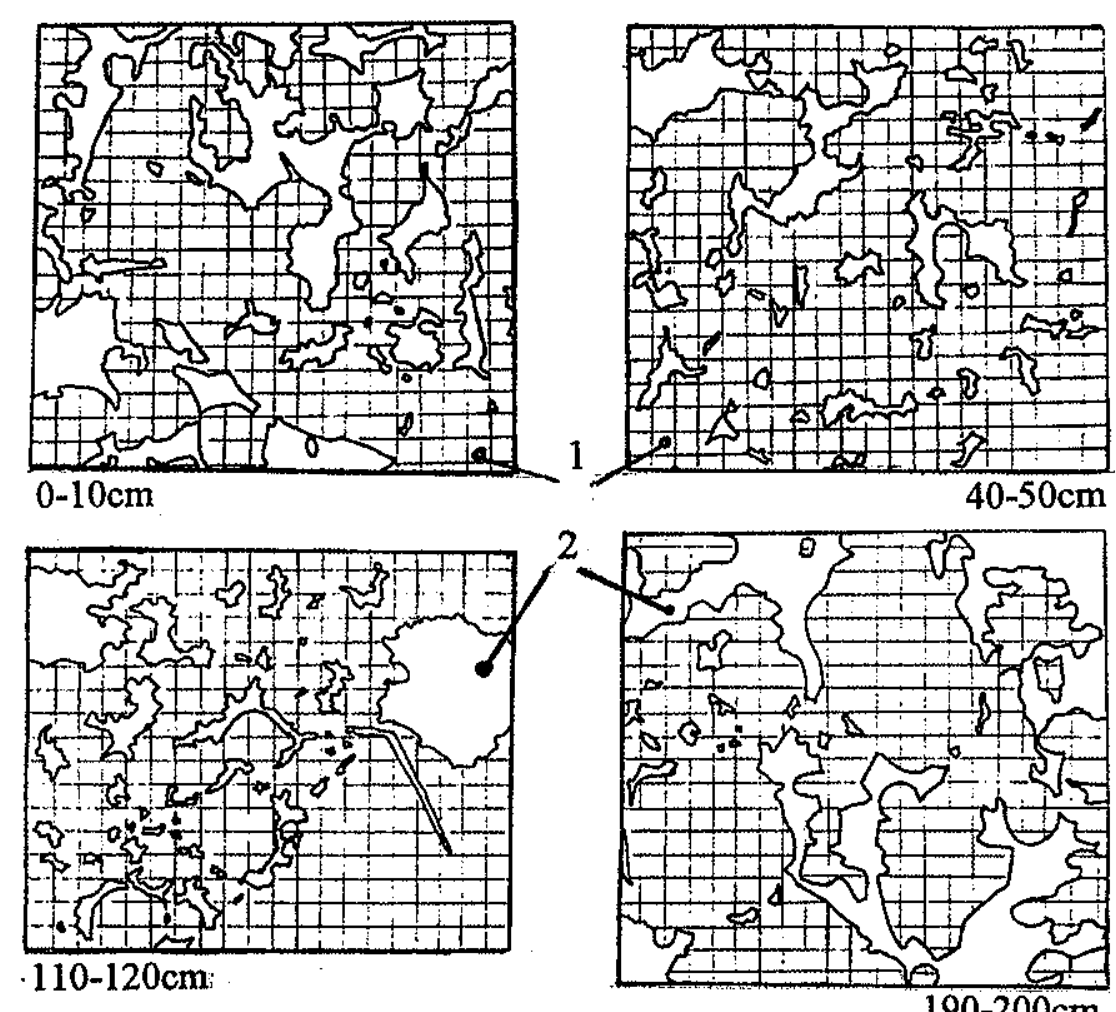

$190-200 \mathrm{~cm}$

Figura 17: Modo de assembléias secundária dos horizontes do Latossolo. 1: fundo matricial de microagregados soldados. 2: meta-cavidades mamelonares fortemente interconectadas. As estruturas microgranulares são contínuas, aglutinadas com forte coalescência. (de Eschenbrenner, 1986, fig.4, p.406).

\subsection{Observação dos microagregados por Microscópio Eletrônico de Varredura (MEV)}

As imagens (figuras 18, 19 e 20) ilustram os principais tipos de microagregados ovoidais ou esferoidais encontrados para cada classe granulométrica.

Os microagregados observados foram selecionados aleatoriamente repetindo-se ao menos três observações de microagregados distintos.

As análises por EDS revelaram que predominam Si e $\mathrm{Al}$ em proporção similar indicando composição de caoliníta.

Os microagregados compostos (com subestruturas) apresentam ponto de junção tendo caolinita como agente de agregação. 

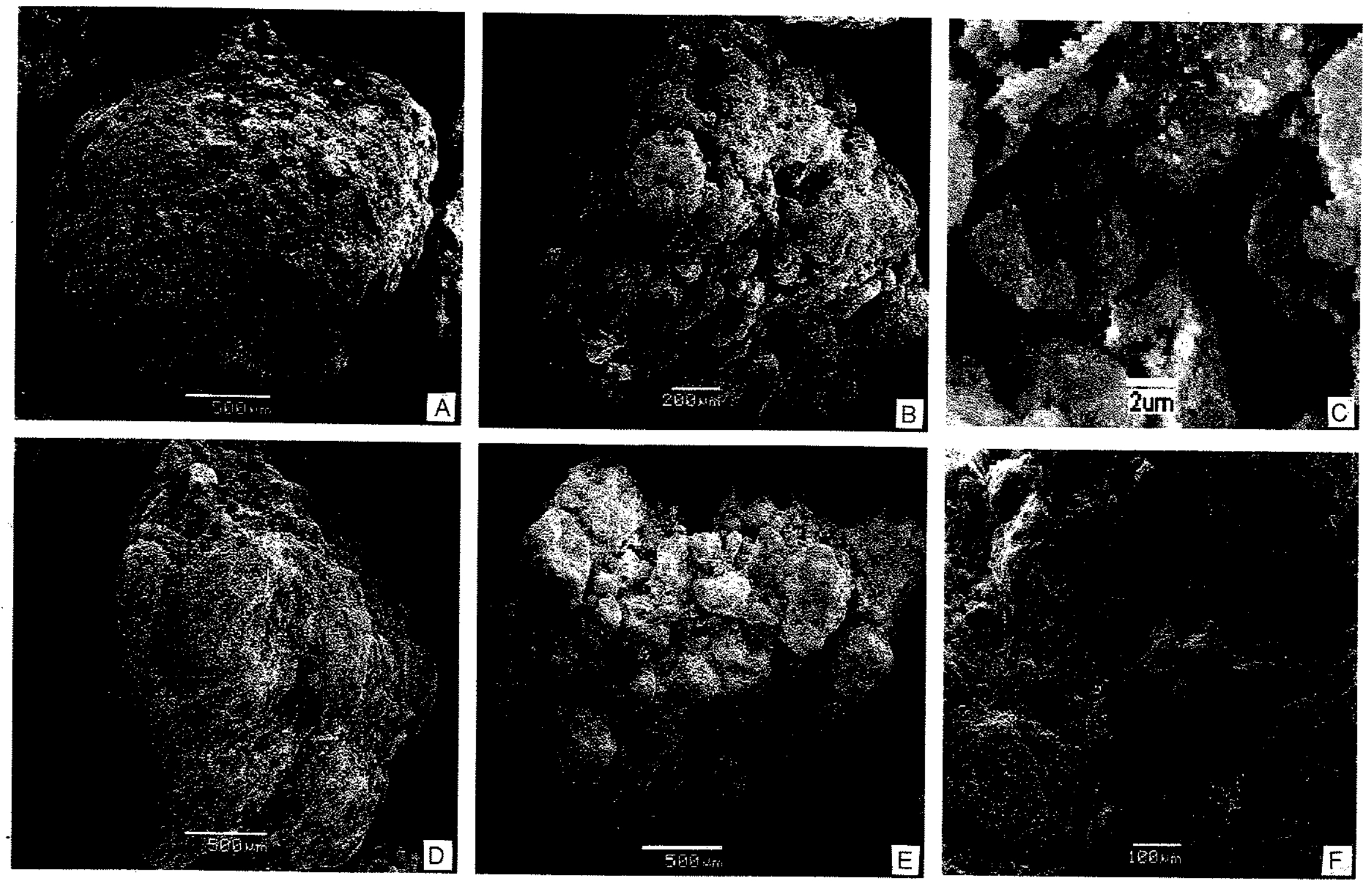

Figura 18: Microscopia Eletrônica de Varredura. Microagregados do Latossolo. Classe $>1 \mathrm{~mm}$. (A) a (C) $0-35 \mathrm{~cm}$ e (D) a (F) $160-200 \mathrm{~cm}$ de profundidade (A) e (E) Microagregado com subestrutura. (B) e (D) Microagregado sem subestrutura (E) Detalhe da superficie do microagregado sem subestrutura (F) arranjo característico da subestrutura do microagregado composto. 

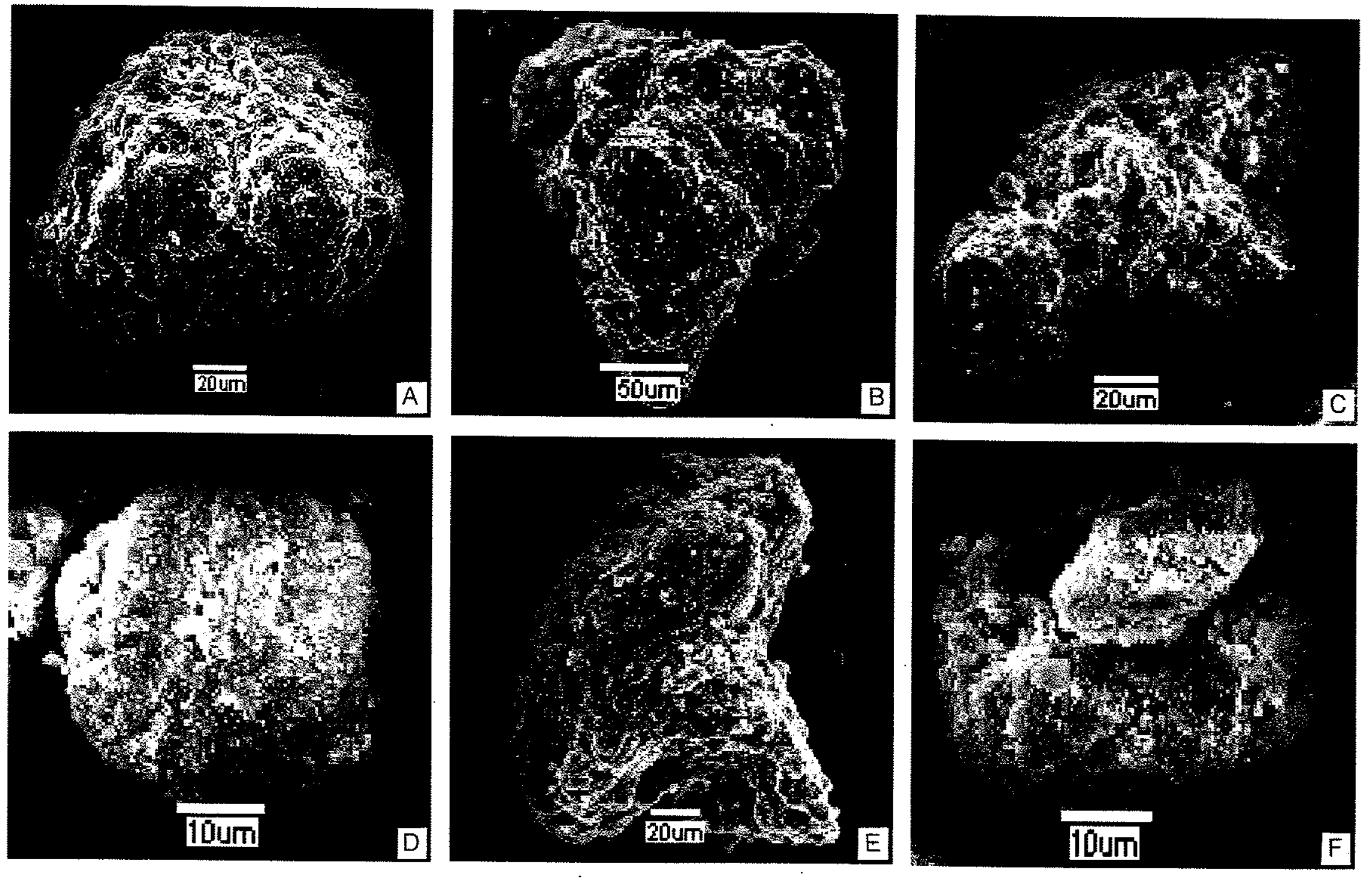

Figura 19: Microscopia eletrônica de varredura. Microagregados do Latossolo. Classe $<0,053 \mathrm{~mm}$. (A) a (C) $0-35 \mathrm{~cm}$ e (D) a (F) $160-200 \mathrm{~cm}$. (A) Microagregado sem subestrutura, esferoidal, com superficie irregular.(B) Microagregado sem subestrutura, superficie irregular (C) Microagregado composto, com subestrutura (D) Microagregado sem subestrutura com superfície esferoidal, irregular (E) Microagregado composto, com subestrutura, superficie irregular, forma ovoidal irregular (F) Microagregado composto com subestrutura. 

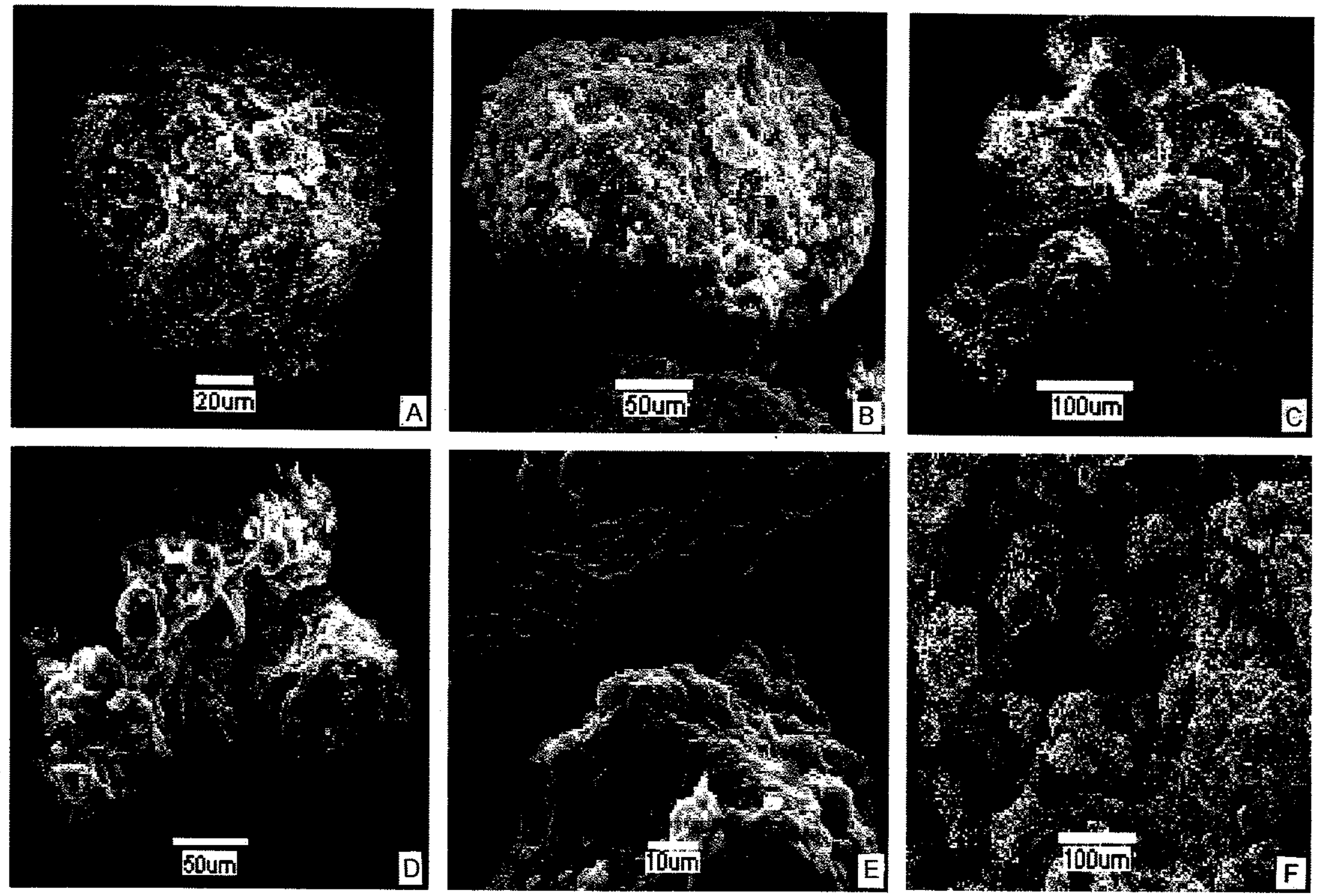

Figura 20: Microscopia eletrônica de Varredura. Microagregados extraídos da parede de canal de cupins encontrados no Latossolo a 100$120 \mathrm{~cm}$ de profundidade (A) e (B) Microagregados sem subestrutura (C) e (D) Microagregados com subestrutura, irregular (E) Detalhe da junção entre os microagregados da subestrutura (F) Parede interna de um canal, com microagregados presos à parede. 


\subsection{Tamanho e morfometria dos microagregados}

O resultado do fracionamento a seco em quatro classes granulométricas é apresentado na tabela 2.

A classe $0,15-1 \mathrm{~mm}$ predomina em todo o perfil. Até $60 \mathrm{~cm}$ de profundidade os microagregados menores que $0,15 \mathrm{~mm}$ representam aproximadamente $11 \%$. A partir de $80 \mathrm{~cm}$ de profundidade, a proporção dos microagregados menores que $0,15 \mathrm{~mm}$ está aumentando, e o aumento está relacionado particularmente ao aumento dos microagregados inferior a $0,053 \mathrm{~mm}$ ( $8 \%$ a $80-120 \mathrm{~cm}, 11 \%$ a $100-120 \mathrm{~cm}$ e $16 \%$ a $160-200 \mathrm{~cm}$ ). Os microagregados separados por peneiramento a seco foram separados sob luz incidente (figuras 21 e 22) e em luz transmitida (figura 23). Os microagregados compostos com subestrutura são presentes em todas as classes, mas predominam na classe $>1 \mathrm{~mm}$ (figura 21 ). $\mathrm{Na}$ classe $0,15-1 \mathrm{~mm}$, os microagregados apresentam-se com uma distribuição de tamanho heterogênea, enquanto nas classes menores $(<0,015 \mathrm{~mm})$, a distribuição apresenta-se mais homogênea (figuras 21 e 22). Sob luz transmitida (figura 23), é possível observar os contornos dos microagregados variando de subangulosos a subarredondados. A figura 23 (B, E) confirma a heterogeneidade de tamanho dos microagregados da classe $0,15-1 \mathrm{~mm}$.

Tabela 2: Fracionamento dos microagregados em 4 classes granulométricas.

\begin{tabular}{|l|c|c|c|c|}
\hline $\begin{array}{c}\text { Profundidade } \\
(\mathrm{cm})\end{array}$ & $\begin{array}{c}<0,053 \mathrm{~mm} \\
(\mathrm{~g} / 100 \mathrm{~g})\end{array}$ & $\begin{array}{c}0,053-0,15 \mathrm{~mm} \\
(\mathrm{~g} / 100 \mathrm{~g})\end{array}$ & $\begin{array}{c}0,15-1 \mathrm{~mm} \\
(\mathrm{~g} / 100 \mathrm{~g})\end{array}$ & $\begin{array}{c}>1 \mathrm{~mm} \\
(\mathrm{~g} / 100 \mathrm{~g})\end{array}$ \\
\hline $0-35$ & 2,6 & 7,9 & 65,4 & 24,1 \\
\hline $40-60$ & 1,7 & 9,0 & 65,5 & 23,8 \\
\hline $80-120$ & 7,8 & 25,2 & 59,1 & 7,9 \\
\hline $100-120$ & 10,7 & 27,9 & 54,8 & 6,6 \\
\hline $160-200$ & 16,0 & 19,1 & 58,9 & 6,0 \\
\hline
\end{tabular}



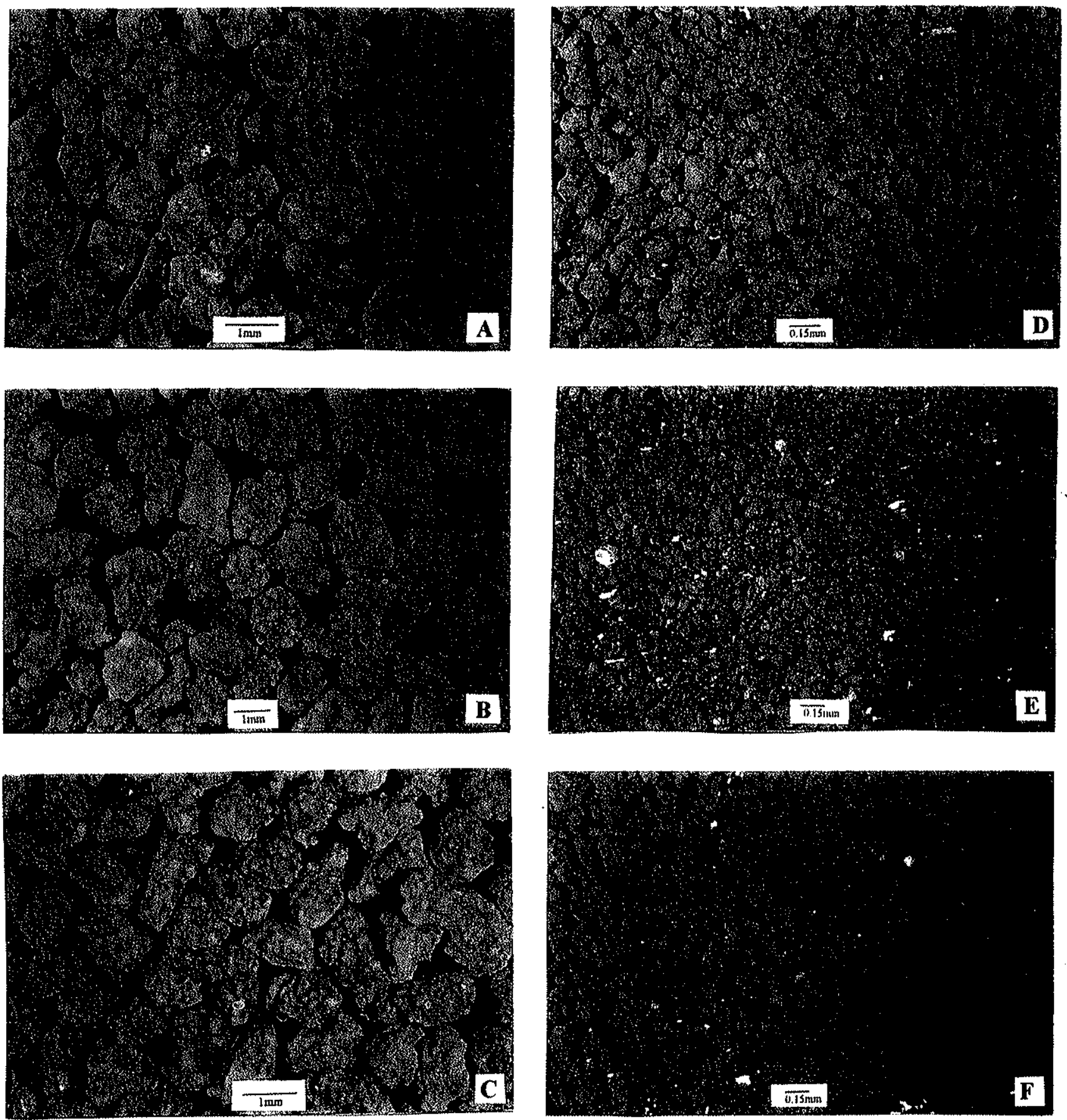

Figura 21: Microagregados separados por fracionamento a seco. (Lupa binocular, aumento de $25 \mathrm{x}$, luz incidente).

Classe $>1 \mathrm{~mm}$. A $(0-35 \mathrm{~cm})$, B $(80-120 \mathrm{~cm})$ e C $(160-200 \mathrm{~cm})$. Observa-se predomínio de microagregados com subestrutura, com forma subesferoidal a subovoidal, com contorno subanguloso a subarredondado.

Classe $0,15-1 \mathrm{~mm}$. Em D $(0-35 \mathrm{~cm}), E(80-120 \mathrm{~cm})$ e $F(160-200 \mathrm{~cm})$ predomina o tipo de microagregado sem subestrutura, com forma subesferoidal e com contorno subarredondado. Em $\mathrm{E}$ e F, aparecem grãos de quartzo dispersos (pontos mais claros). 

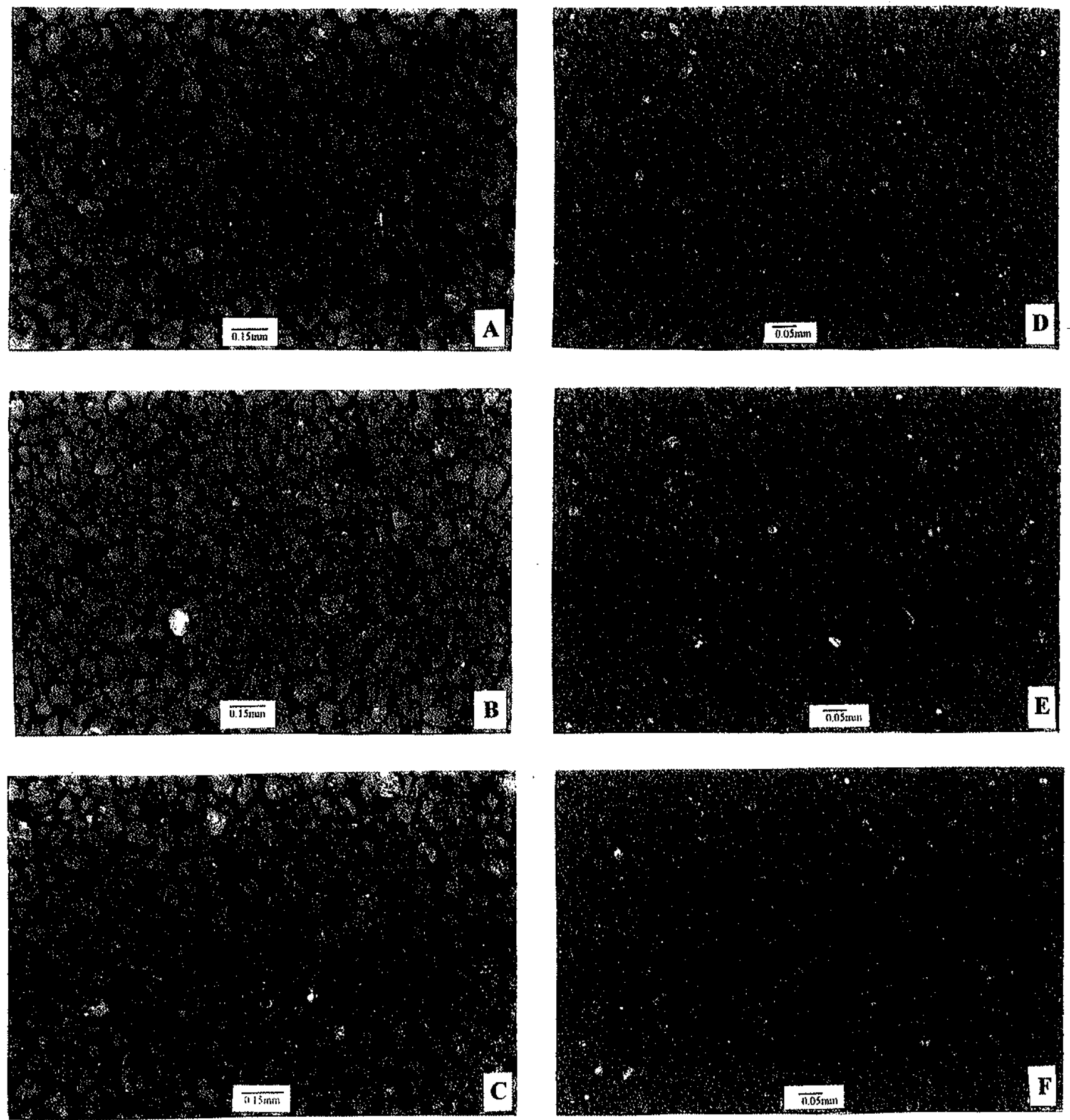

Figura 22: Microagregados separados por fracionamento a seco. (Lupa binocular, aumento de $50 \mathrm{x}$, luz incidente).

Classe $0,053-0,15 \mathrm{~mm}$. Em A $(0-35 \mathrm{~cm})$, B $(80-120 \mathrm{~cm})$ e C $(160-200 \mathrm{~cm})$. Observa-se a forte homogeneidade do tamanho dos microagregados com predomínio de microagregados sem subestrutura, de forma subovoidal a esferoidal, com contorno arredondado.

Classe $<0,053 \mathrm{~mm}$. Em D $(0-35 \mathrm{~cm}), \mathrm{E}(80-120 \mathrm{~cm})$ e F $(160-200 \mathrm{~cm})$. Homogeneidade do tamanho dos microagregados, predomínio dos microagregados sem subestrutura, de forma subesferoidal e com contorno subarredondado. Em E e F aumentam grãos de quartzo dispersos. 

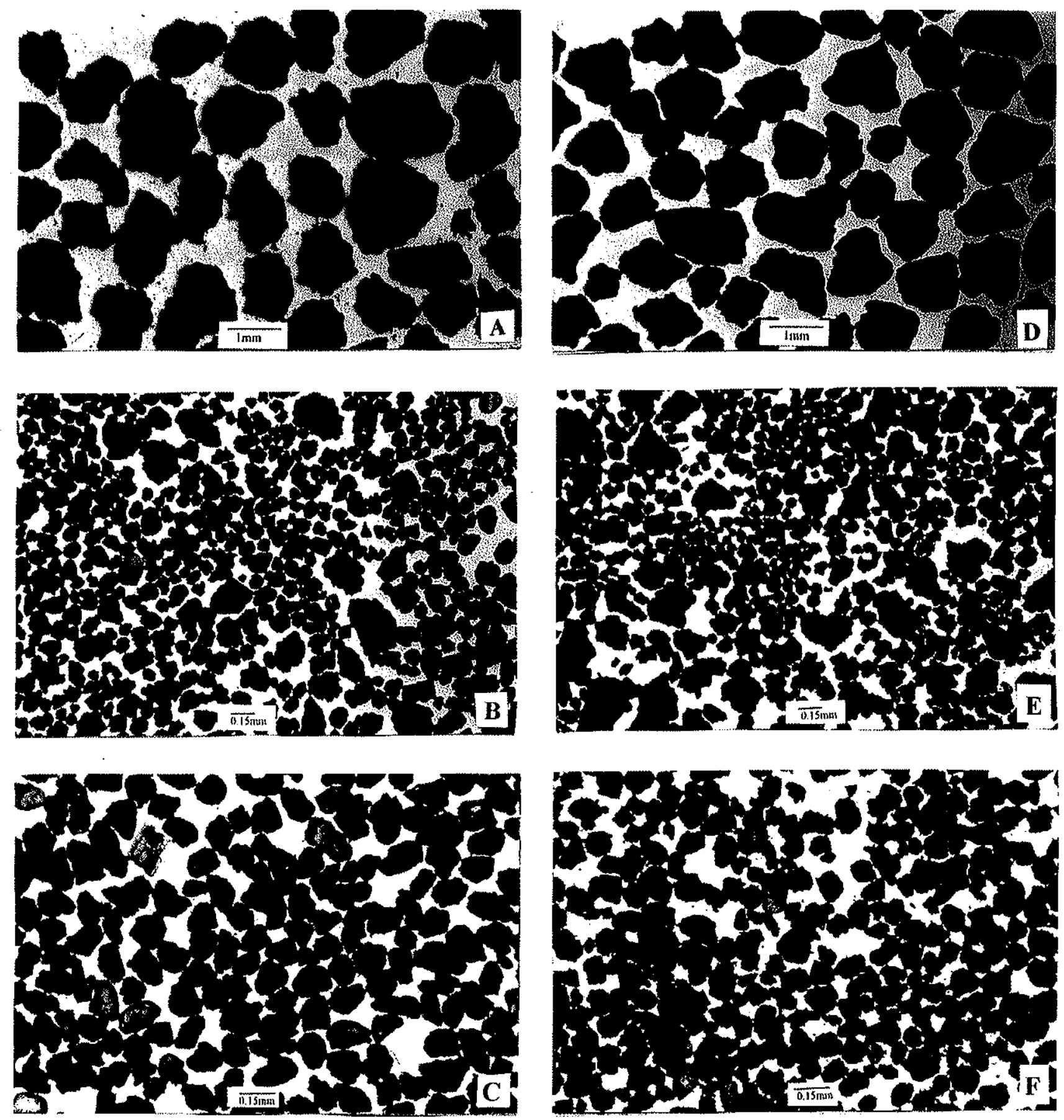

Figura 23: Microagregados separados por fracionamento a seco. (Lupa binocular, aumento de 30x, luz tansmitida).

Em A, B e C profundidade de $0-35 \mathrm{~cm}$. Em A (classe $>1 \mathrm{~mm})$, B (classe $0,15-1 \mathrm{~mm})$ e C $(0,053$ $0,15 \mathrm{~mm}$ ). Em D, E e F profundidade de $160-200 \mathrm{~cm}$. Em D (classe $>1 \mathrm{~mm}$ ), E (classe $0,15-1 \mathrm{~mm}$ ) e $\mathrm{F}$ (classe $0,053-0,15 \mathrm{~mm}$ ). Observa-se os contornos subangulosos a subarredondados e a forte heterogeneidade do tamanho dos microagregados na classe $0,15-1 \mathrm{~mm}(\mathrm{~B}, \mathrm{E})$. 
A caracterização morfoscópica dos microagregados do Latossolo foi feita para cada classe granulométrica e o resultado mostra uma concentração das razões entre 0,6 e 1 (figuras 24 a 26), revelando uma dominância das formas esferoidais, o que é confirmado pela relação morfométrica B/A e C/B (tabela 3).

Tabela 3: Razão morfométrica $\mathrm{B} / \mathrm{A}$ e $\mathrm{C} / \mathrm{B}$ para os microagregados.

\begin{tabular}{|l|c|c|c|c|c|c|c|c|}
\hline \multirow{2}{*}{$\begin{array}{c}\text { Profundidade } \\
\text { (cm) }\end{array}$} & \multicolumn{9}{|c|}{ Classes granulométricas } \\
\cline { 2 - 9 } & \multicolumn{2}{|c|}{$<0,053 \mathrm{~mm}$} & \multicolumn{2}{c|}{$0,053-0,15 \mathrm{~mm}$} & \multicolumn{2}{c|}{$0,15-1 \mathrm{~mm}$} & \multicolumn{2}{c|}{$>1,0 \mathrm{~mm}$} \\
\hline $0-35$ & $0,74 \pm 0,18$ & $0,78 \pm 0,18$ & $0,85 \pm 0,18$ & $0,86 \pm 0,16$ & $0,84 \pm 0,16$ & $0,85 \pm 0,15$ & $0,78 \pm 0,19$ & $0,77 \pm 0,19$ \\
& & & & & & & & \\
\hline $40-60$ & $0,76 \pm 0,16$ & $0,78 \pm 0,16$ & $0,89 \pm 0,13$ & $0,86 \pm 0,16$ & $0,87 \pm 0,18$ & $0,83 \pm 0,15$ & $0,81 \pm 0,13$ & $0,78 \pm 0,15$ \\
& & & & & & & & \\
\hline $80-120$ & $0,86 \pm 0,16$ & $0,77 \pm 0,19$ & $0,85 \pm 0,15$ & $0,91 \pm 0,1$ & $0,82 \pm 0,17$ & $0,76 \pm 0,18$ & $0,78 \pm 0,16$ & $0,75 \pm 0,15$ \\
& & & & & & & & \\
\hline $100-120$ & $0,86 \pm 0,15$ & $0,80 \pm 0,18$ & $0,86 \pm 0,14$ & $0,84 \pm 0,14$ & $0,86 \pm 0,14$ & $0,83 \pm 0,17$ & $0,71 \pm 0,14$ & $0,87 \pm 0,14$ \\
& & & & & & & & \\
\hline $160-200$ & $0,86 \pm 0,15$ & $0,82 \pm 0,17$ & $0,87 \pm 0,14$ & $0,87 \pm 0,12$ & $0,82 \pm 0,15$ & $0,83 \pm 0,15$ & $0,76 \pm 0,13$ & $0,78 \pm 0,16$ \\
& & & & & & & & \\
\hline
\end{tabular}

Observação: $\mathrm{B} / \mathrm{A}$ e $\mathrm{C} / \mathrm{B}$ razões morfométricas definidas no ítem 4.2 .5

$O$ estudo da esfericidade $\mathrm{e}$ do arredondamento mostrou a predominância de microagregados de alta esfericidade com valores variando entre 0,7 a 0,9 (figuras 27 a 31 ). $\mathrm{O}$ arredondamento é bastante variável entre 0,3 (agregados subangulosos) a 0,9 (agregados bem arredondados). Observa-se contudo a predominância de agregados subarredondados $(0,7)$ a arredondados $(0,9)$ nas maiores profundidades.

A partir das curvas de arredondamento e esfericidade (figuras 27 a 31) pode-se concluir de maneira geral que os valores de arredondamento e esfericidade são nitidamente maiores e menos variável em direção a profundidade.

A análise dos microagregados baseada na classificação proposta por Trapnell \& Webster (1986) indica predomínio de microagregados 1) do tipo maciço, sem subestrutura que apresenta forma subesférica a esférica, arredondada com superficie sem rugosidade e com moderada resistência mecânica à saturação; 2) Tipo composto com subestrutura, com junção entre microagregados menores de $100 \mu \mathrm{m}$ de diâmetro, de forma subesférica, com fraca resistência mecânica quando levemente umidecidos; 3) Tipo anguloso ou fragmentário, com arestas vivas ou fraturadas, provavelmente por quebra mecânica dos tipos 1 e 2 . 

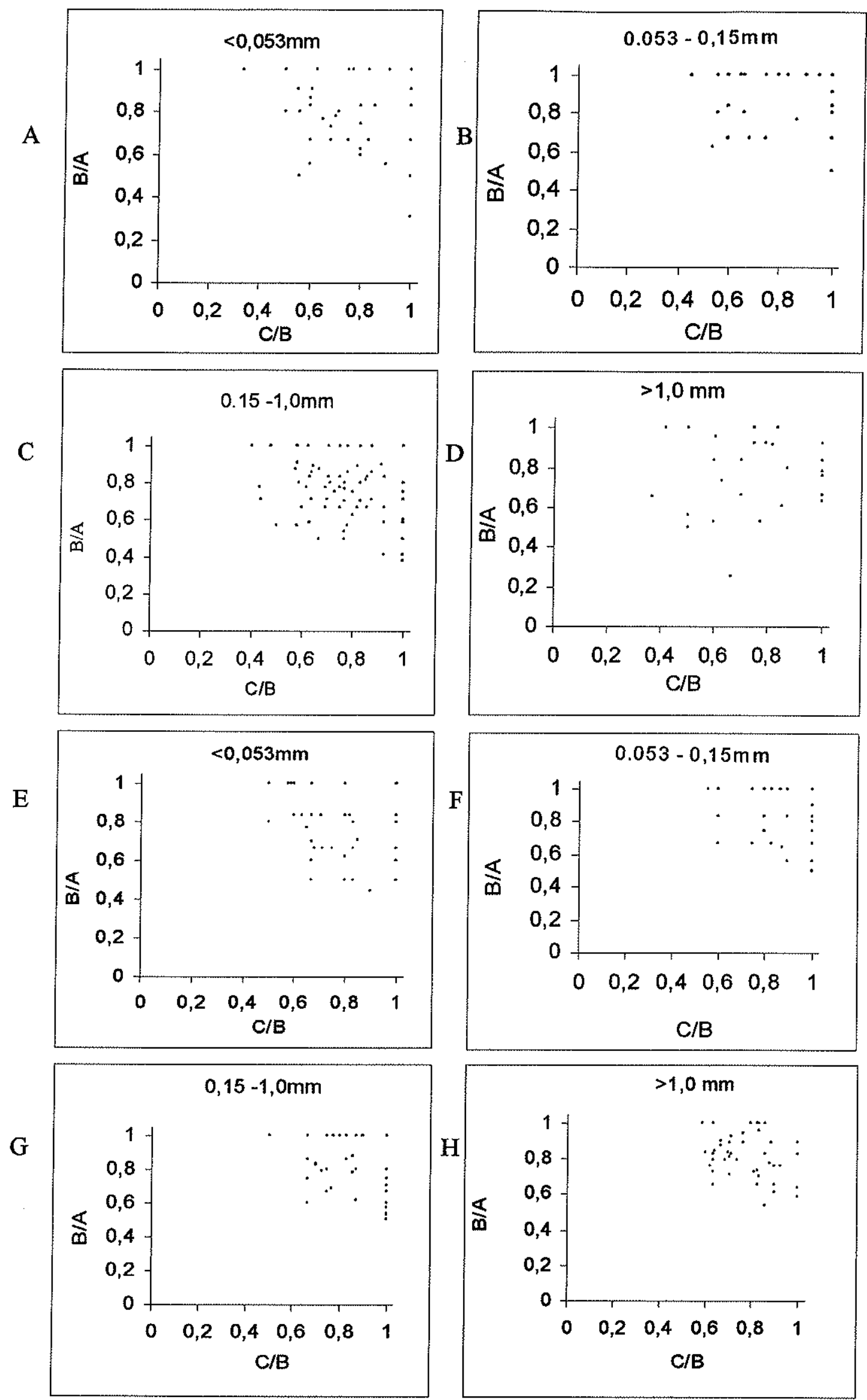

Figura 24: Morfometria ilustrada pelas razões B/A e C/B. (A) a (D) profundidade $0-35 \mathrm{~cm}$ (E) a (H) profundidade $40-60 \mathrm{~cm}$. 

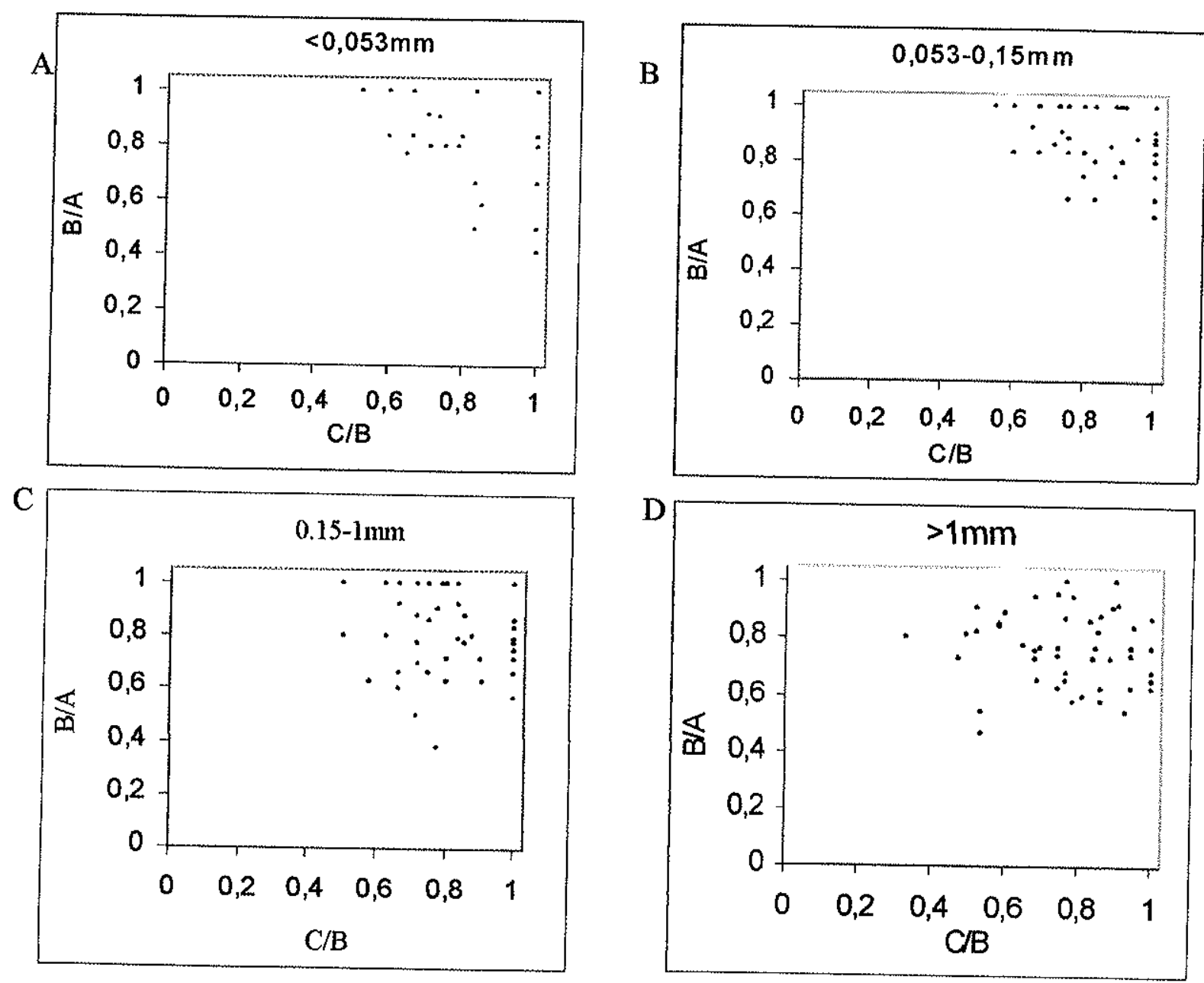

Figura 26: Morfometria ilustrada pelas razões B/A e C/B. profundidade $160-200 \mathrm{~cm}$. 

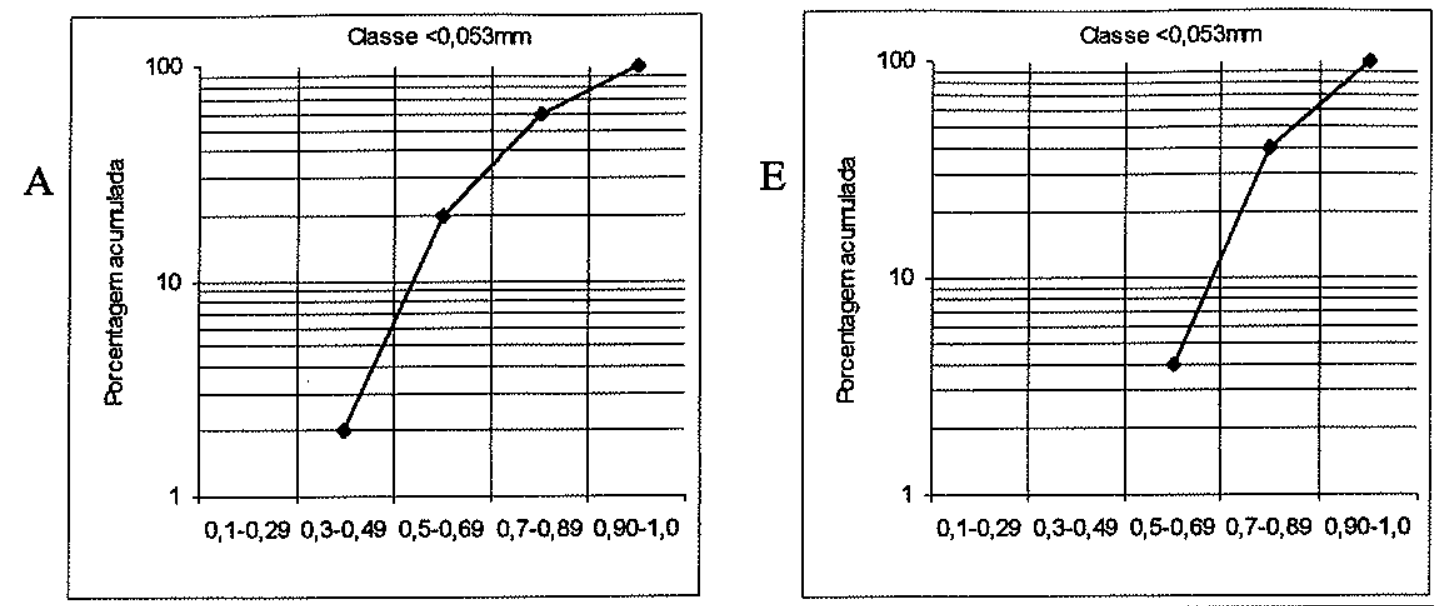

B

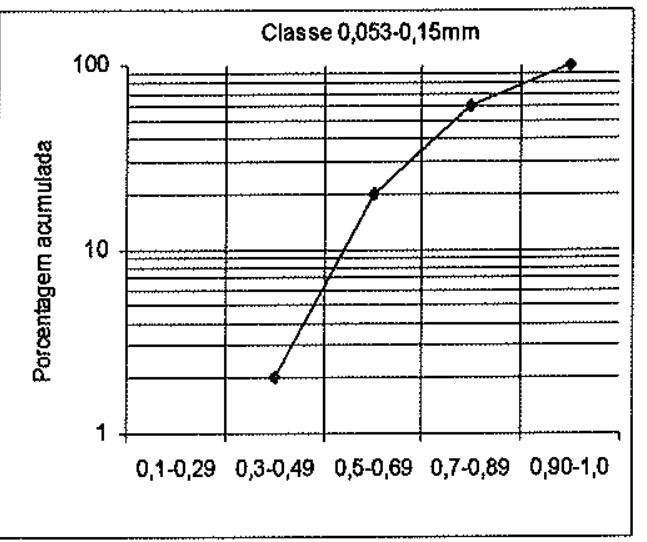

$\mathrm{C}$

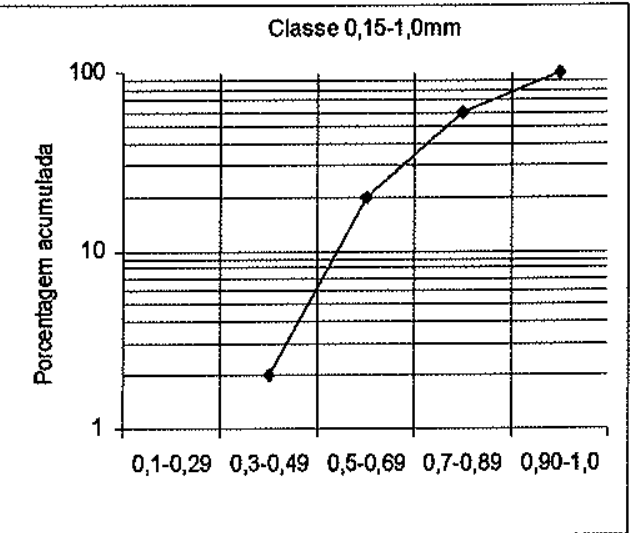

$\mathrm{D}$

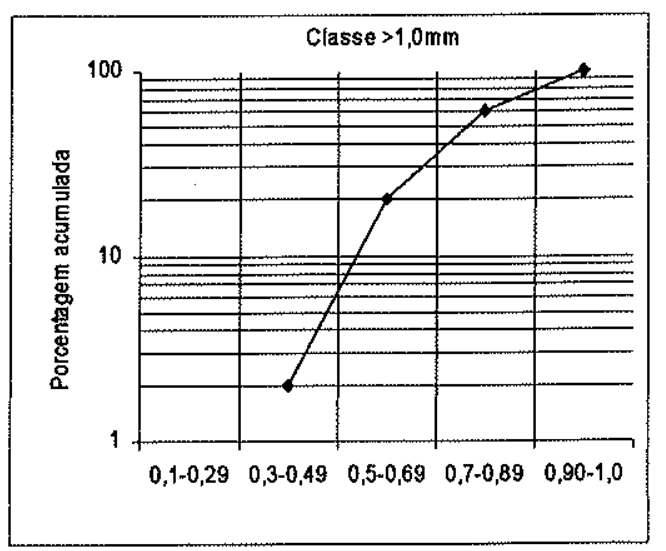

Classe de arredondamento

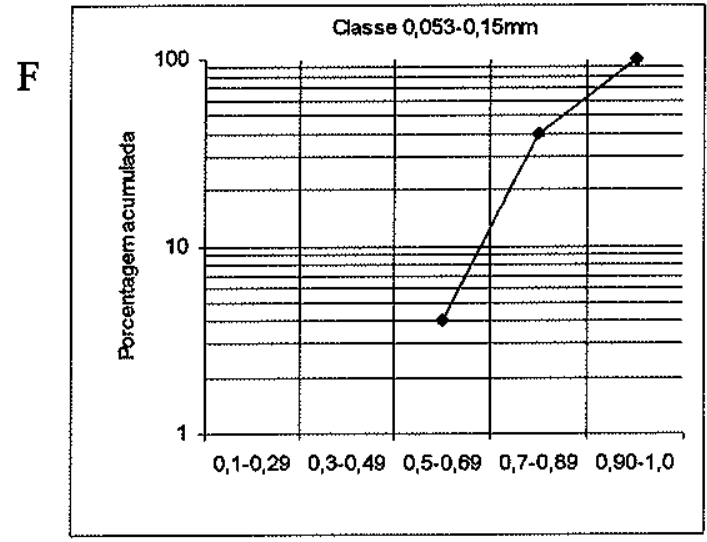

G
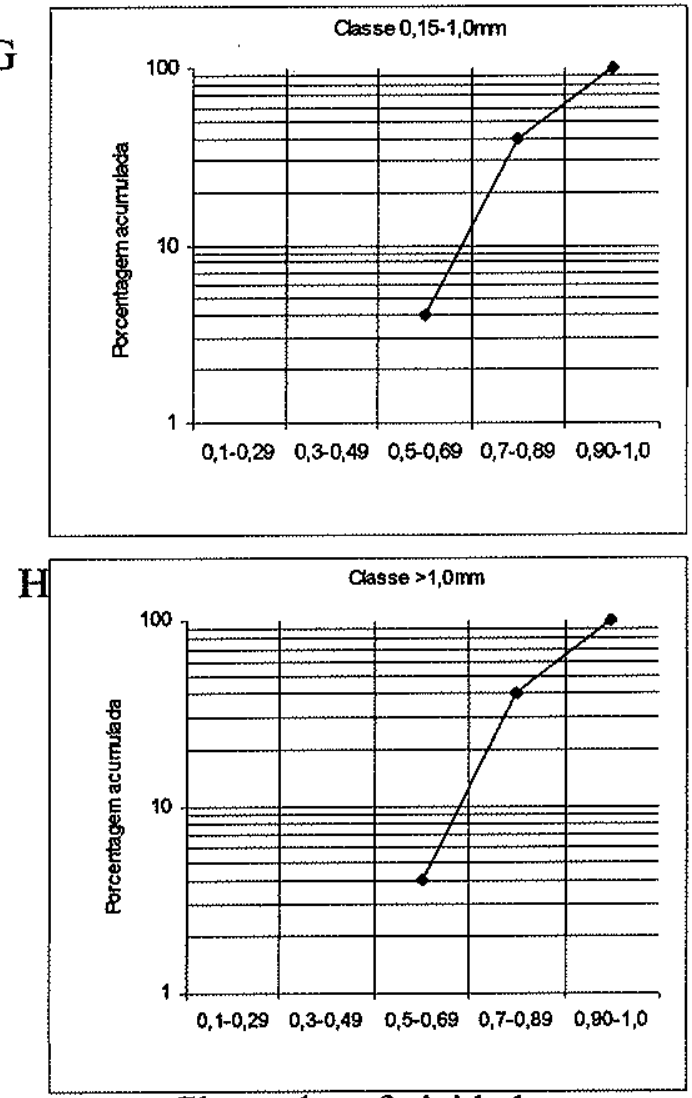

Classe de esfericidade

Figura 27: Arredondamento e esfericidade, profundidade $0-35 \mathrm{~cm}$. A a D Curvas cumulativas da distribuição do arredondamento para cada classe. E a H Curvas cumulativas da distribuição da esfericidade para cada classe. 
A

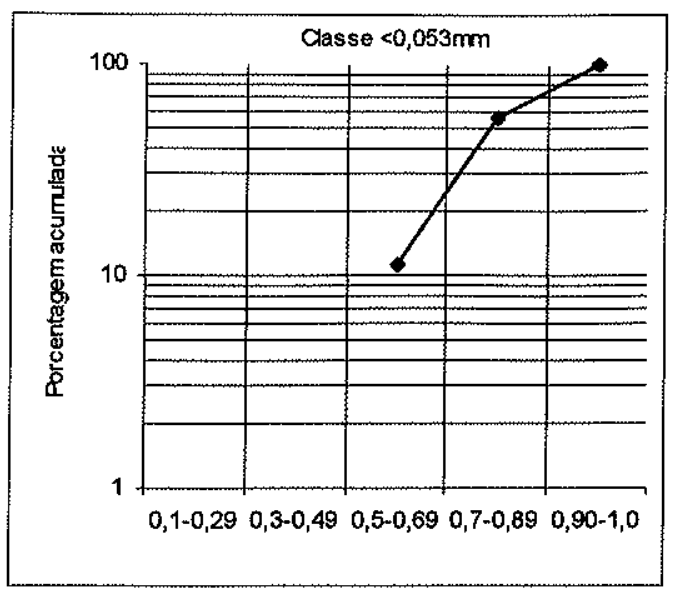

B

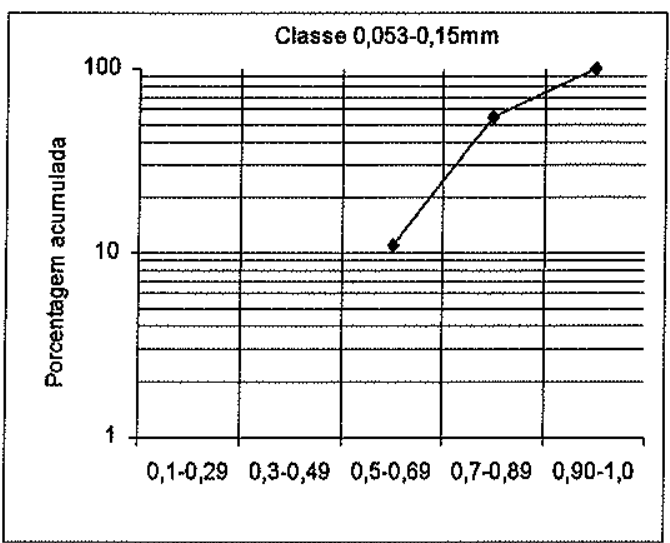

$\mathrm{C}$
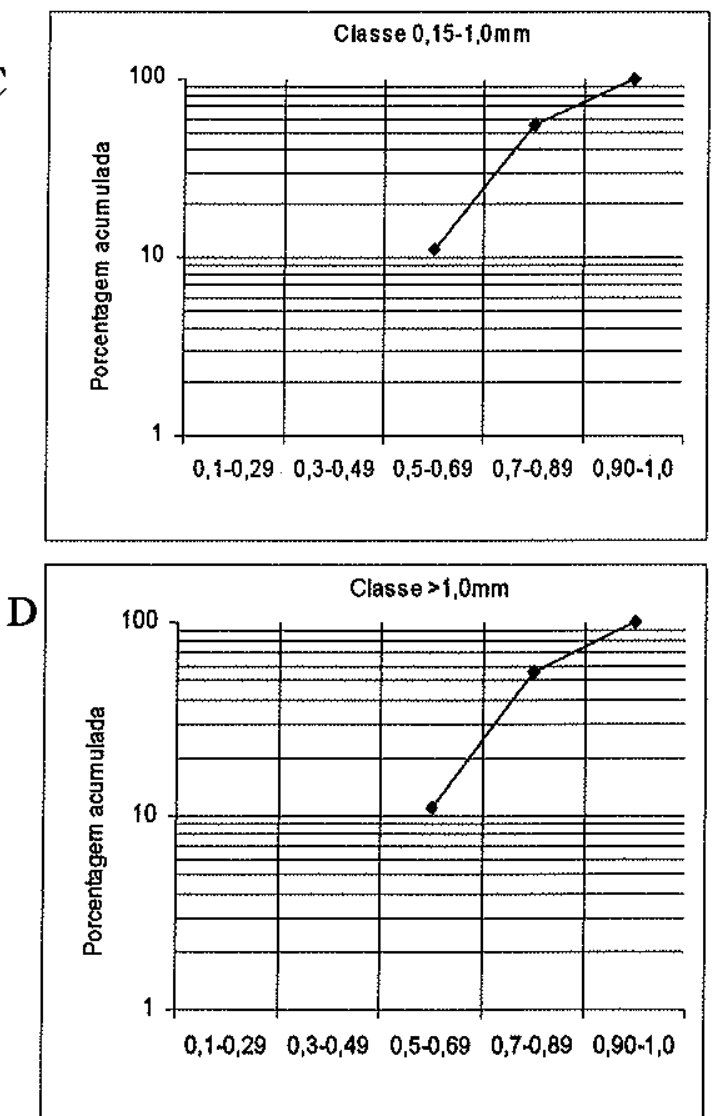

Classe de arredondamento

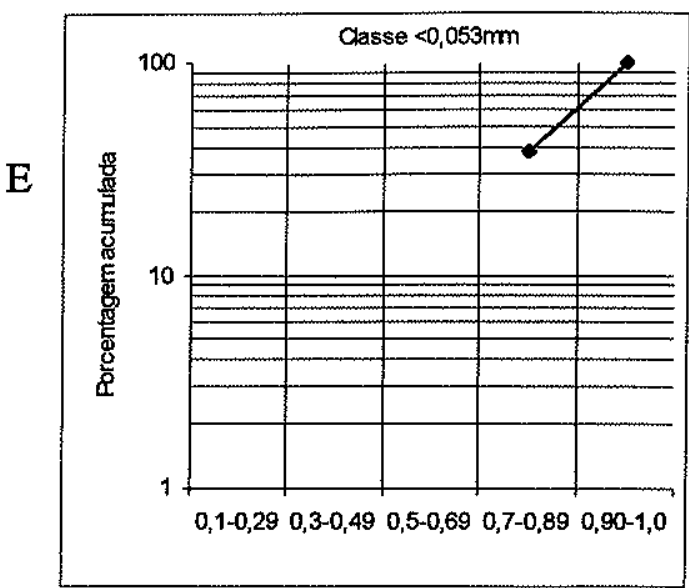

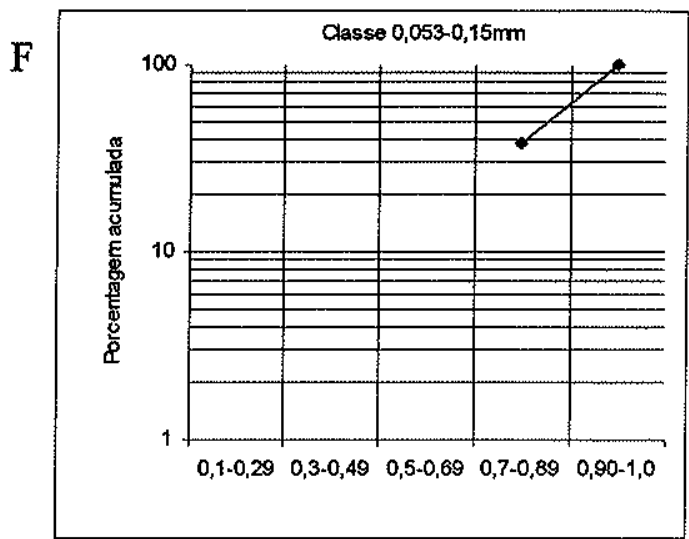
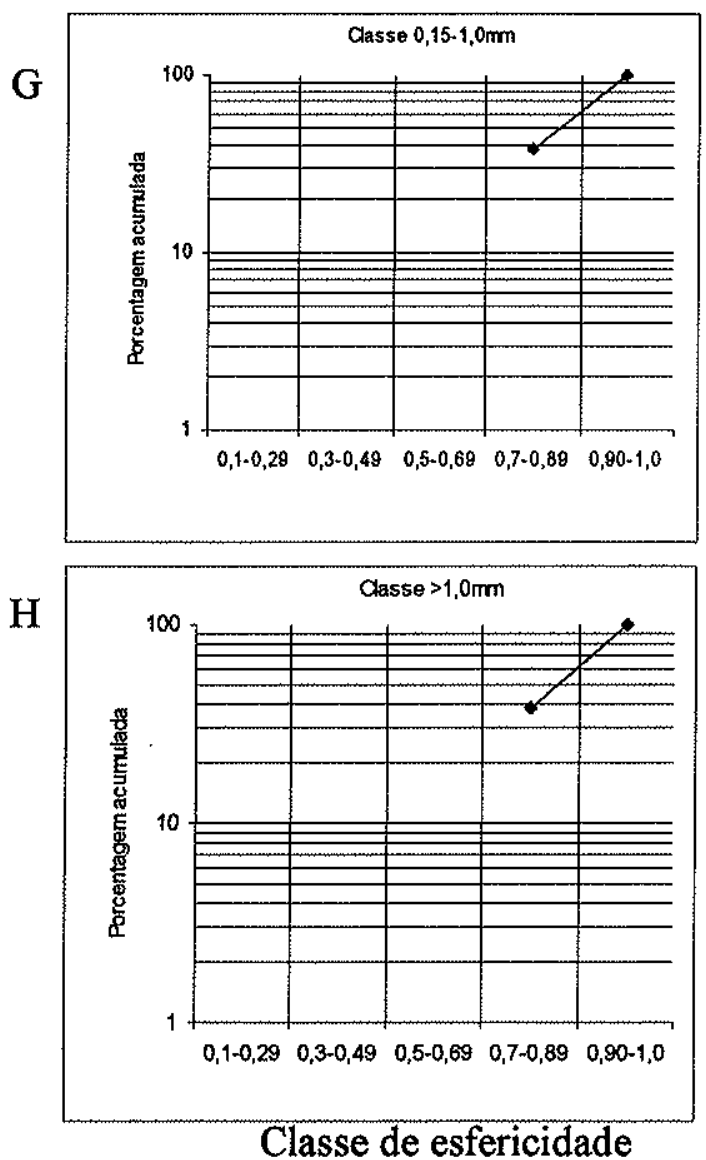

Figura 28: Arredondamento e esfericidade, profundidade $40-60 \mathrm{~cm}$. A a D Curvas cumulativas da distribuição do arredondamento para cada classe. $\mathrm{E}$ a $\mathrm{H}$ Curvas cumulativas da distribuição da esfericidade para cada classe. 
A

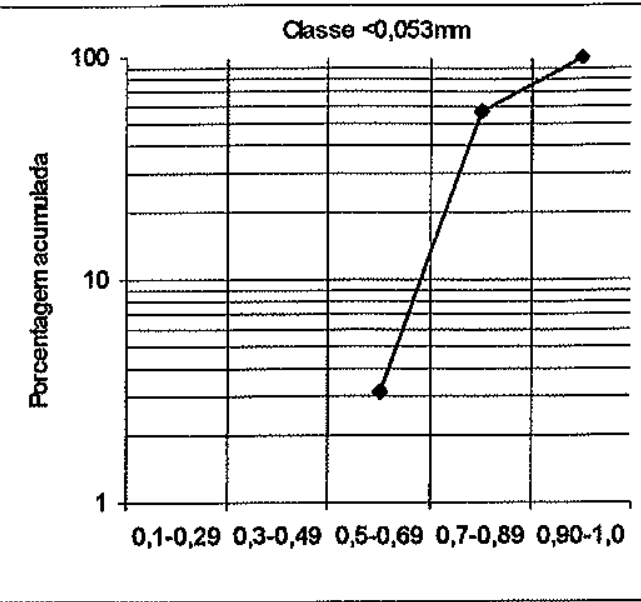

B

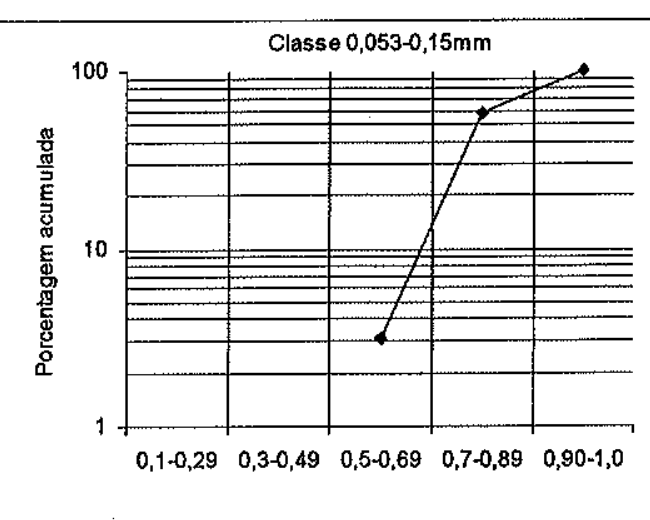

$\mathrm{C}$

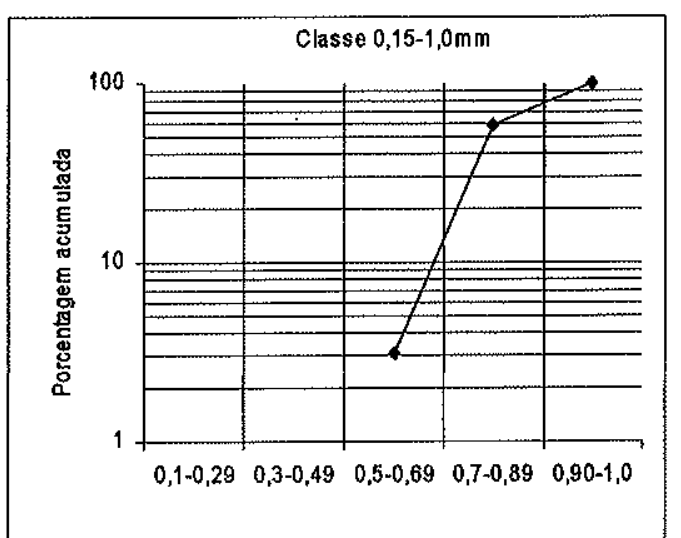

D

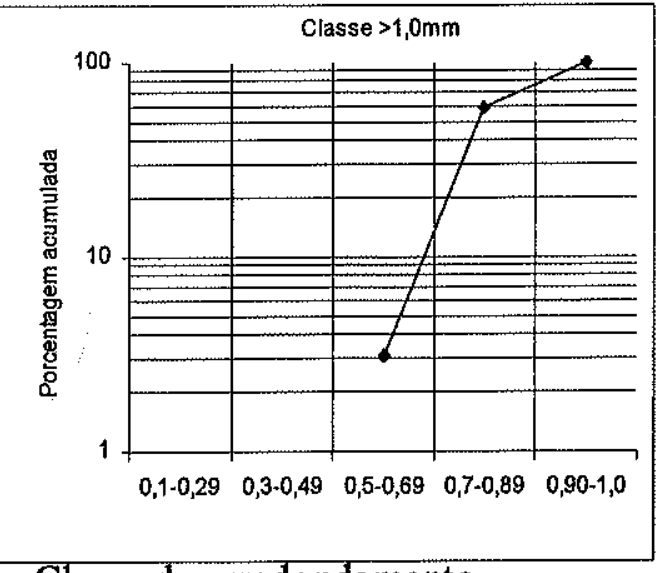

Classe de arredondamento
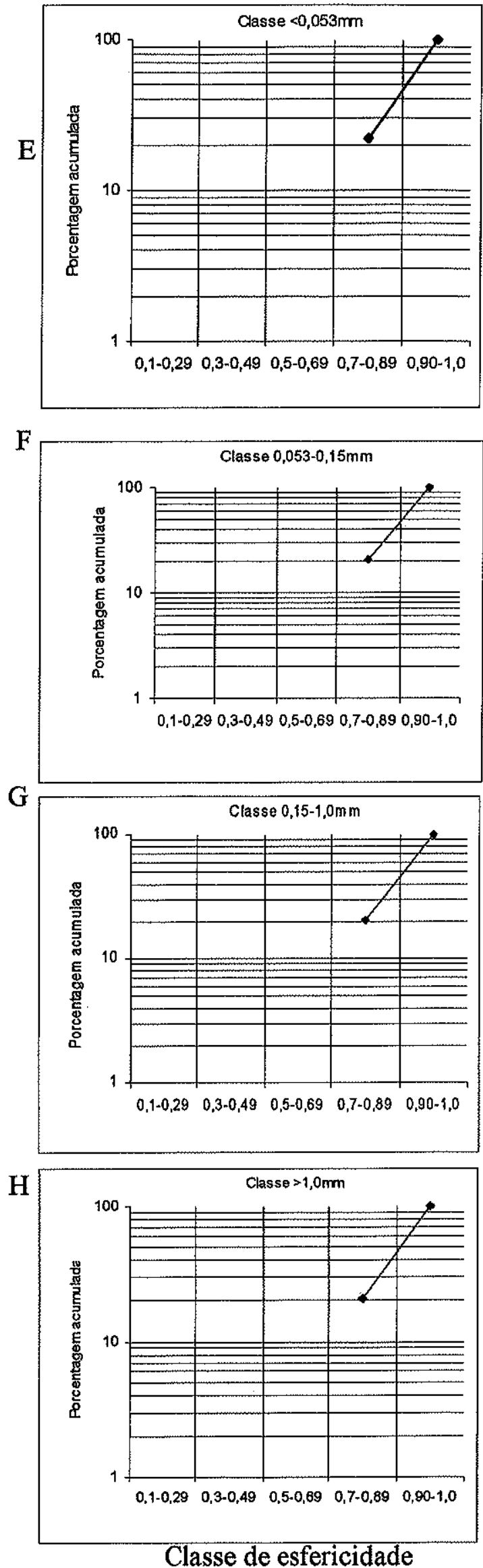

Classe de esfericidade

Figura 30: Arredondamento e esfericidade, profundidade $100-120 \mathrm{~cm}$. A a D Curvas cumulativas da distribuição do arredondamento para cada classe. $\mathrm{E}$ a $\mathrm{H}$ Curvas cumulativas da distribuição da esfericidade para cada classe. 

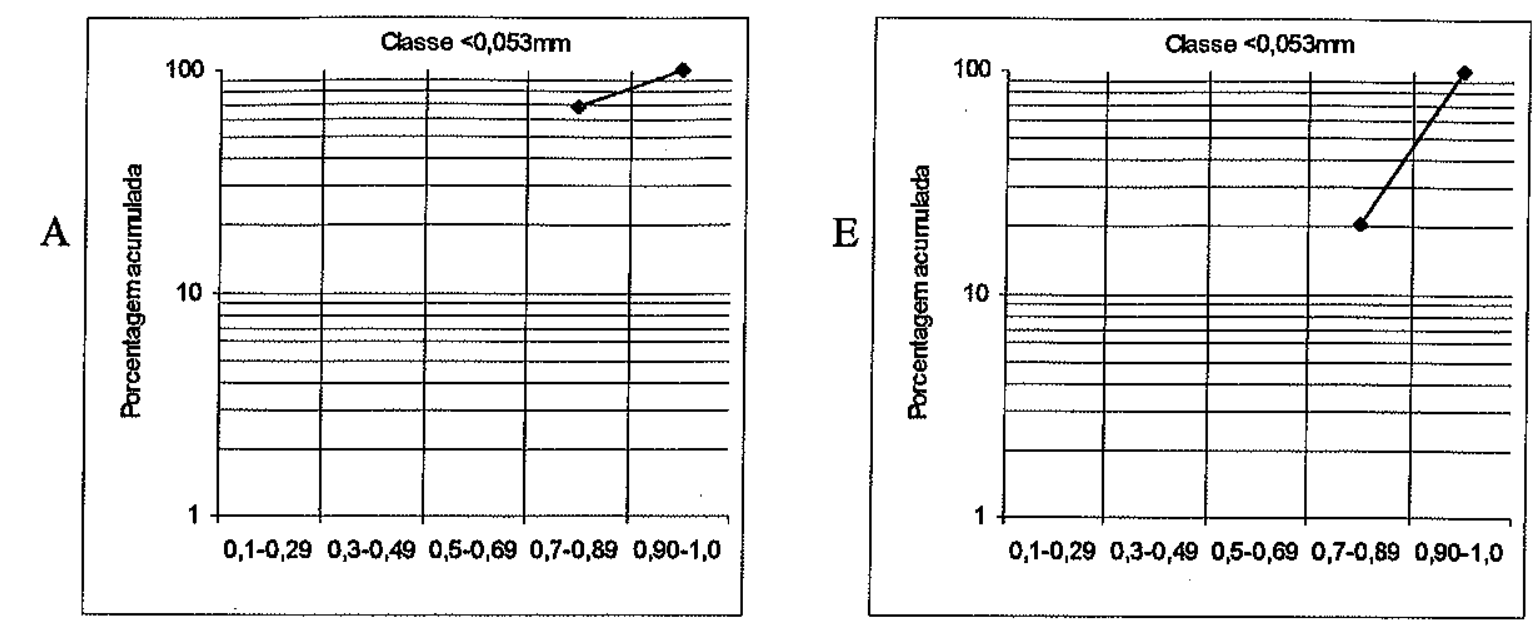

B

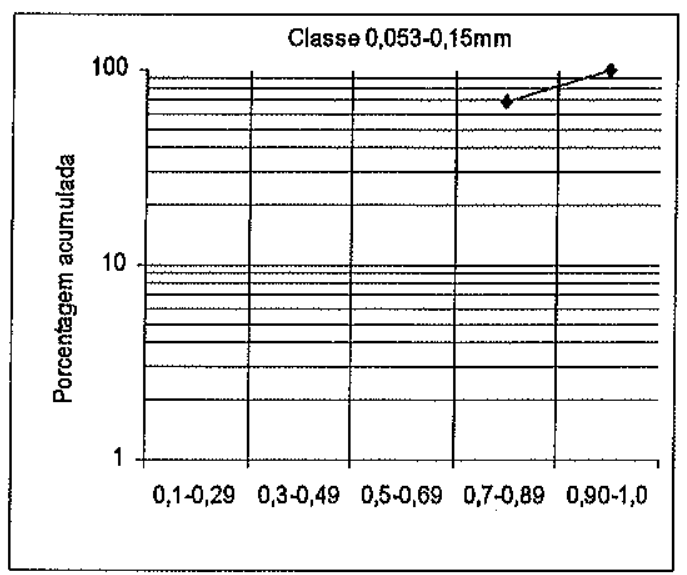

$\mathrm{C}$

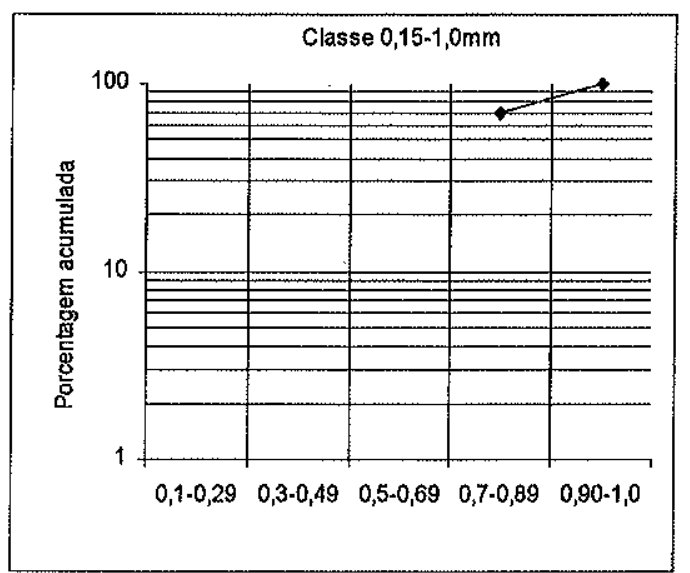

D

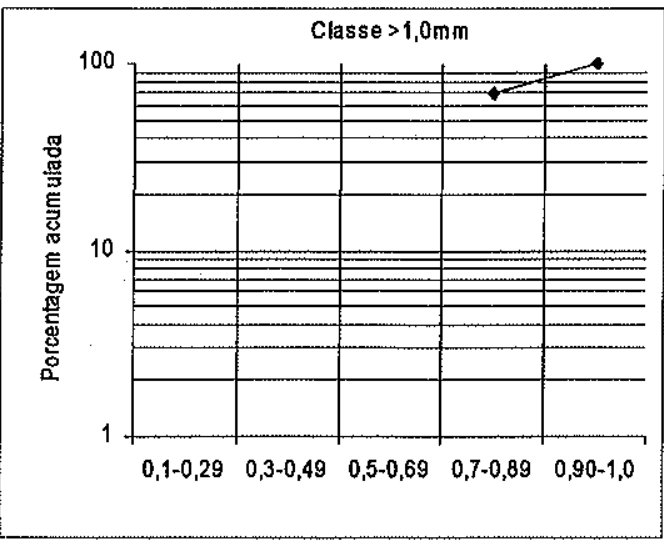

Classe de arredondamento
F

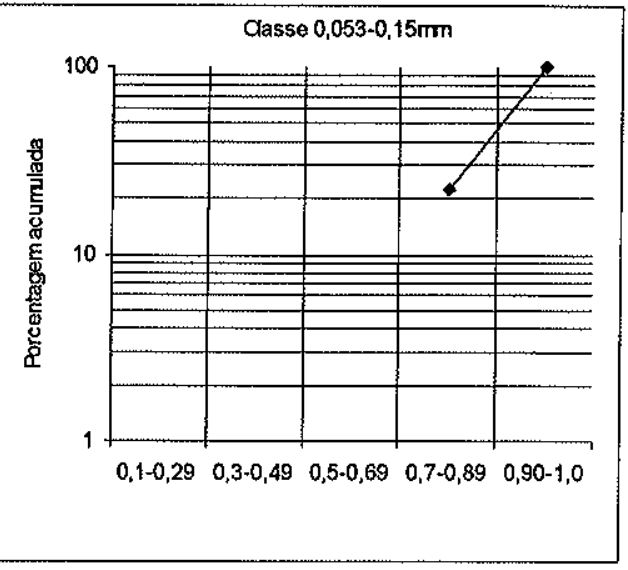

G

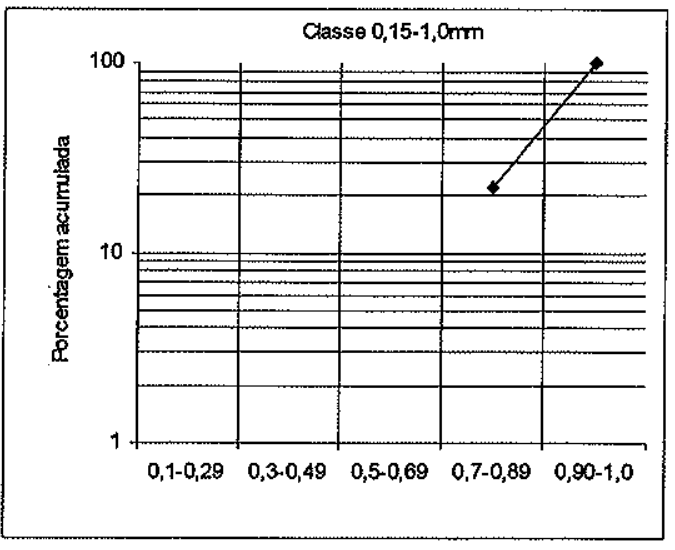

$\mathrm{H}$

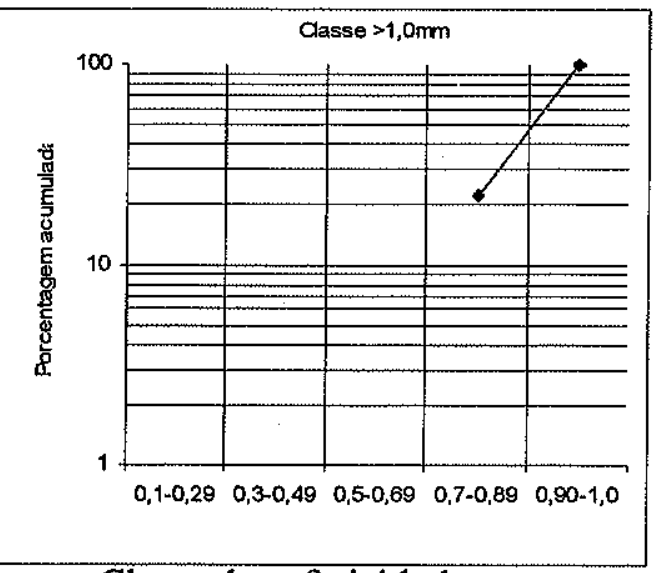

Classe de esfericidade

Figura 31: Arredondamento e esfericidade, profundidade $160-200 \mathrm{~cm}$. A a D Curvas cumulativas da distribuição do arredondamento para cada classe. $\mathrm{E}$ a $\mathrm{H}$ Curvas cumulativas da distribuição da esfericidade para cada classe. 


\subsection{Caracterização da resistência dos microagregados à desagregação}

Realizou-se ensaios de resistência à desagregação conforme a proposta de Trapnel \& Webster (1986), para estabelecer a relação entre os tipos de microagregados e os comportamentos sob condição hídrica distintas. Realizou-se os ensaios com uma pequena quantidade (cerca de 1g) de microagregados, colocando-os inicialmente em placa de Petri sobre papel filtro umidecido, saturando-os com água e depois em dispersante (hidróxido de sódio, $0,1 \mathrm{~N})$. A tabela 2 sintetiza o resultado da observação por microscopia com os tratamentos. De modo geral, todos os tipos presentes nas diferentes classes apresentam boa estabilidade quando umidecidos .

O tipo composto (com subestrutura), que ocorre somente na classe $>1 \mathrm{~mm}$ (em todas as profundidades) apresentou-se instável quando saturado em água e em solução alcalina, se desagregando em microagregados menores, de $100 \mu \mathrm{m}$, de forma subesferoidal a esferoidal estáveis em água e instáveis em solução alcalina.

O tipo maciço (sem subestrutura) é estável sob saturação em água, absorvendo água lentamente quando comparado ao tipo composto, desfazendo-se totalmente quando submetido à solução alcalina.

O tipo de desagregação do microagregado, como por exemplo dispersão plasma e esqueleto e quebras angulosas, podem refletir particularidades quanto ao conteúdo em argila, tipo de agente agregante e podem ser utilizadas como uma característica indicativa para diferentes tipos de microagregados conforme destacado por Trapell \& Webster (1986). 
Tabela 4: Resistência à desagregação em diferentes condições hídricas.

\begin{tabular}{|c|c|c|c|c|c|}
\hline \multirow{2}{*}{$\begin{array}{l}\text { Profundidade } \\
\text { do solo } \\
\text { (cm) }\end{array}$} & \multirow{2}{*}{$\begin{array}{c}\text { Classe } \\
\text { granulométrica }\end{array}$} & \multicolumn{3}{|c|}{ Tratamento } & \multirow[b]{2}{*}{$\begin{array}{c}\text { Tipo de } \\
\text { desagregação* }\end{array}$} \\
\hline & & $\begin{array}{l}\text { Saturaça por } \\
\text { capflaridade }\end{array}$ & $\begin{array}{l}\text { Imersăo } \\
\text { Em H2O }\end{array}$ & $\begin{array}{l}\text { Imersăo em soluçăo } \\
\text { NaOH } 0,1 \mathrm{~N}\end{array}$ & \\
\hline \multirow{4}{*}{$0-35$} & $>1 \mathrm{~mm}$ & 0 & $\begin{array}{l}\mathrm{X} \text { composto } \\
\text { O maciģo }\end{array}$ & $\begin{array}{l}\mathrm{XX} \text { composto } \\
\mathrm{X} \text { maciço }\end{array}$ & $\begin{array}{l}\text { Composto (1) } \\
\text { Maciço(1)(2) }\end{array}$ \\
\hline & $0,15 \mathrm{kmm}$ & o & $x$ & $x x$ & $(1),(2)$ \\
\hline & $0,053-0,15 \mathrm{~mm}$ & $o$ & 0 & $x x$ & $(1),(2)$ \\
\hline & $<0,53 \mathrm{~mm}$ & 0 & 0 & $x x$ & (1), (2) \\
\hline \multirow{4}{*}{$40-60$} & $>\operatorname{lmm}$ & 0 & $\begin{array}{l}\mathrm{X} \text { composto } \\
\mathrm{O} \text { maciço } \\
\end{array}$ & \begin{tabular}{|l|}
$\mathrm{XX}$ composto \\
$\mathrm{X}$ maciço \\
\end{tabular} & \begin{tabular}{|l|} 
Composto (1) \\
Maciço(1) (2) \\
\end{tabular} \\
\hline & $0,15 \cdot 1 \mathrm{~mm}$ & 0 & $x$ & $\mathrm{xx}$ & $(1),(2)$ \\
\hline & $0,053-0,15 \mathrm{~mm}$ & 0 & 0 & $x x$ & $(1),(2)$ \\
\hline & $<0,053 \mathrm{~mm}$ & 0 & 0 & $x x$ & $(1),(2)$ \\
\hline \multirow{4}{*}{80.120} & $>1 \mathrm{~mm}$ & 0 & $\begin{array}{l}\mathrm{X} \text { composto } \\
\text { O maci̧̧o }\end{array}$ & $\begin{array}{l}\mathrm{XX} \text { composto } \\
\mathrm{X} \text { maciço }\end{array}$ & $\begin{array}{l}\text { Composto (1) } \\
\text { Macigo (1),(2) }\end{array}$ \\
\hline & $0,15-1 \mathrm{~mm}$ & 0 & 0 & $x x$ & (1) \\
\hline & $0,053-0,15 \mathrm{~mm}$ & 0 & 0 & $x x$ & (1), (2) \\
\hline & $<0,053 \mathrm{~mm}$ & 0 & 0 & $\mathrm{xx}$ & $(1),(2)$ \\
\hline \multirow{4}{*}{$100-120$} & $>\operatorname{lmm}$ & 0 & $\begin{array}{l}X \text { composto } \\
\text { O maciģo } \\
\end{array}$ & \begin{tabular}{|l|}
$\mathrm{XX}$ composto \\
$\mathrm{X}$ macico \\
\end{tabular} & \begin{tabular}{|l|} 
Composto (1) \\
Maciço (1),(2) \\
\end{tabular} \\
\hline & $0,015 \cdot 1 \mathrm{~mm}$ & 0 & 0 & $x x$ & (1) (2) \\
\hline & $0,053-0,15 \mathrm{~mm}$ & 0 & 0 & $x x$ & $(1),(2)$ \\
\hline & $<0,053 \mathrm{~mm}$ & 0 & 0 & $x x$ & $(1),(2)$ \\
\hline \multirow{4}{*}{$160-200$} & $>1 \mathrm{~mm}$ & 0 & $\begin{array}{l}\mathrm{X} \text { composto } \\
\text { O maciģo }\end{array}$ & $\begin{array}{l}\mathrm{XX} \text { composto } \\
\mathrm{X} \text { maciço }\end{array}$ & $\begin{array}{l}\text { Composto (1) } \\
\text { Maciço (1),(2) }\end{array}$ \\
\hline & $0,15-1 \mathrm{~mm}$ & 0 & 0 & $\mathrm{xx}$ & $(1),(2)$ \\
\hline & $0,053-0,15 \mathrm{~mm}$ & 0 & 0 & $x x$ & $(1),(2)$ \\
\hline & $<0,053 \mathrm{~mm}$ & 0 & 0 & $x x$ & $(1),(2)$ \\
\hline
\end{tabular}

Desagregação: (o) ausente $(\mathrm{x})$ presente $(\mathrm{xx})$ muito freqüente. Tipo de desagregação (1) dispersão plasma-esqueleto, (2) quebra angulosa. 


\subsection{Densidade aparente e densidade do sólido}

A densidade aparente que varia entre 1,15 a 1,28 é típica de horizontes subsuperficiais $(0$ $70 \mathrm{~cm}$ ) de um Latossolo (Oliveira \& Menk, 1984; Curmi et al., 1994). A partir de $100 \mathrm{~cm}$ de profundidade, os valores variam de 0,9 a 1,0 (figura 32), sendo bastante característicos do horizonte latossólico $\left(\mathrm{B}_{\mathrm{L}}\right)$. Os valores de densidade de sólido (tabela 5), variam entre $2,44 \mathrm{~g} / \mathrm{cm}^{3}$ $(80-120 \mathrm{~cm})$ a $2,67 \mathrm{~g} / \mathrm{cm}^{3}(0-35 \mathrm{~cm})$ e são característicos para os Latossolos de um modo geral (Oliveira \& Menk, 1984).

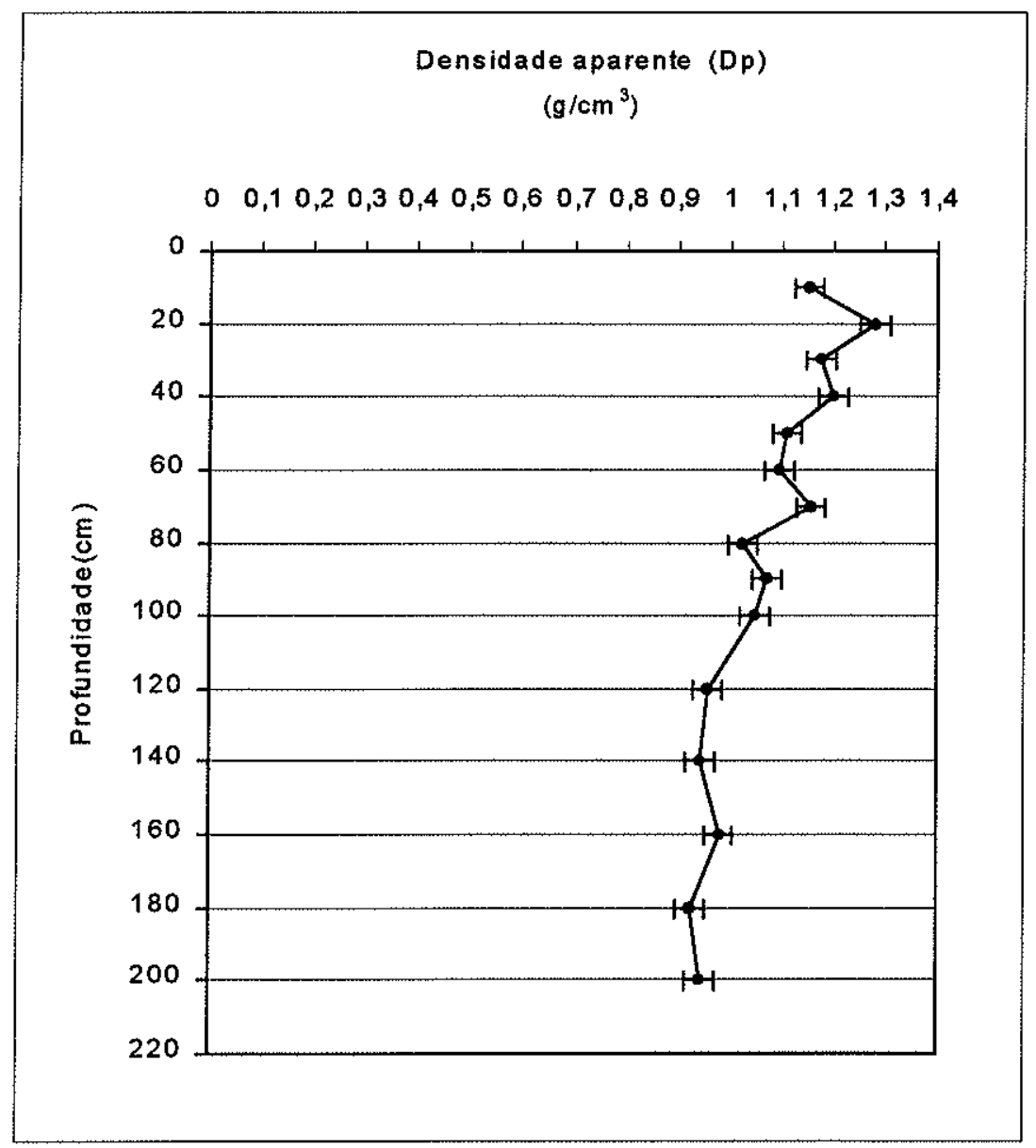

Figura 32: Densidade aparente ao longo do perfil. 
5.8 Distribuição do tamanho dos microagregados (experimentação por granulometria à laser)

Os dados de granulometria com dispersante químico das amostras (tabela 5) indicam uma distribuição argilosa com $70 \%$ de argila na composição total de todas as amostras.

A aplicação do método sobre amostras de microagregados do Latossolo (frações $<1 \mathrm{~mm}$ ) apresentou limitação, sobretudo em relação à distribuição do diâmetro modal de partículas superiores a $0,6 \mathrm{~mm}$ (limite de detecção do aparelho). As profundidades $0-35 \mathrm{~cm}$ e $40-60 \mathrm{~cm}$, o diâmetro modal é superior a $0,5 \mathrm{~mm}$ para mais que $50 \%$ das partículas (figura 33 ). Este resultado deve ser interpretado pela incapacidade do aparelho de discriminar diâmetro de dimensão superior a $0,6 \mathrm{~mm}$. No entanto o resultado é coerente com o predomínio de microagregados da classe $0,15-1 \mathrm{~mm}$ nas profundidades entre $0-60 \mathrm{~cm}$ (tabela 2 ). Nas profundidades de $80-100 \mathrm{~cm}$, $100-120 \mathrm{~cm}$ e $160-200 \mathrm{~cm}$, os diâmetros modais estão em torno de $150 \mu \mathrm{m}$ e com uma distribuição das partículas entre 30 a $300 \mu \mathrm{m}$. Para estas três profundidades deve haver populações de microagregados similares. A curva granulométrica intitulada "100-120cm desagregado", confirmou a eficiência na quebra dos microagregados, demonstrado pela separação da população em duas populações com diâmetros modais de 3 a $300 \mu \mathrm{m}$. Respectivamente, as duas populações correspondem a argilominerais e grãos minerais. 

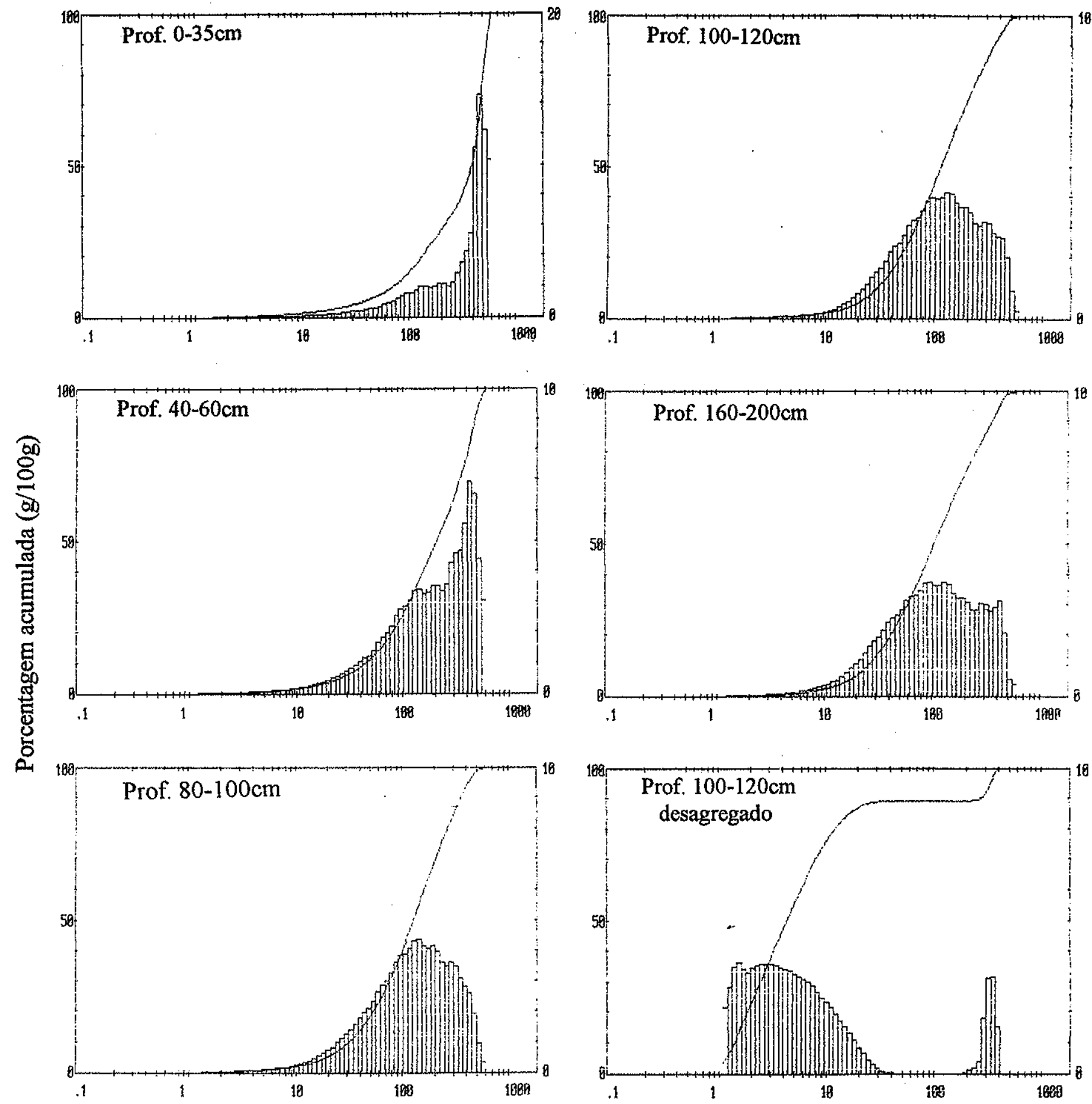

Diâmetro das partículas $(\mu \mathrm{m})$

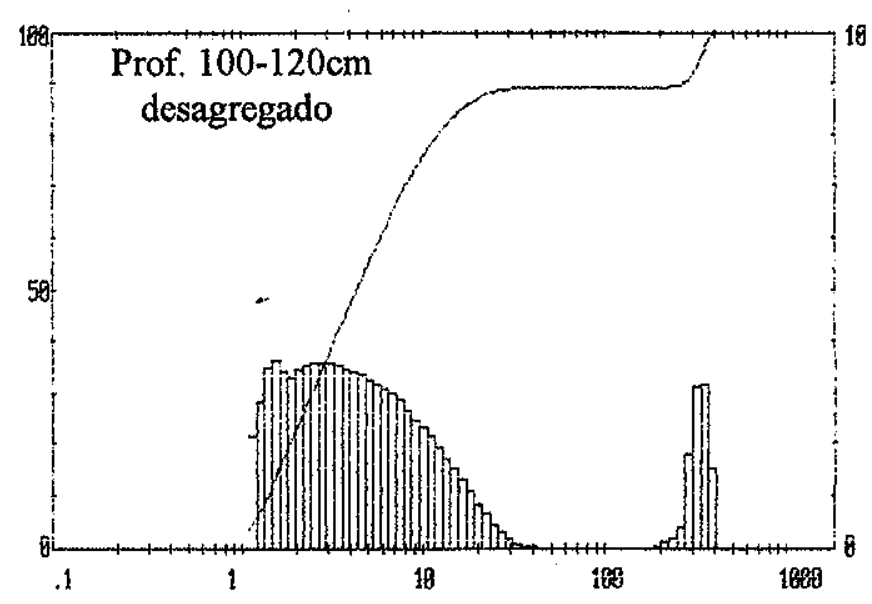

Diâmetro das partículas $(\mu \mathrm{m})$

Figura 33: Distribuição do tamanho dos microagregados do Latossolo, determinada por granulômetro a laser. 


\subsection{Caracterização química dos microagregados do Latossolo}

$\mathrm{Na}$ tabela 5 , estão apresentados os resultados das análises químicas efetuadas sobre as amostras fracionadas por peneiramento a $2 \mathrm{~mm}$ :

pH: $\mathrm{O} \mathrm{pH}$ (em água) é de 4,5 em superfície $(0-35 \mathrm{~cm})$ e varia entre 5,6 e $5,1 \mathrm{em}$ profundidade. $\mathrm{O}$ valor do $\mathrm{pH}$ em $\mathrm{KCl}$ e $\mathrm{CaCl}_{2}$ é menor que 0,6 ao $\mathrm{pH}$ em água, caracterizando um solo com acidez média, apresentando uma forte similaridade com os Latossolos Roxos do Estado de São Paulo (Oliveira \& Menk, 1984). O valor do $\mathrm{pH}$ em superfície é correlacionado ao aumento do teor de matéria orgânica. A partir de $40 \mathrm{~cm}$ de profundidade, a variação do $\mathrm{pH}$ é de pequena amplitude $(0,4)$ diretamente correlacionada à variação das bases totais (SB).

Saturação em bases_(SB): observa-se redução dos teores de cátions trocáveis com a profundidade, chegando a dez vezes para o cálcio (comparado-se valores de $40-60 \mathrm{~cm}$ e 160 $200 \mathrm{~cm}$ ), o que representa uma perda absoluta das bases.

Capacidade de troca catiônica: A capacidade de troca catiônica (T), apresenta variação decrescente com a profundidade, que esta associada em parte, pela diminuição do teor em matéria orgânica no mesmo sentido. $\mathrm{O} \mathrm{Ca}^{2+}$ é o cátion trocável predominante e o solo está desaturado. $\mathrm{O}$ teor de $\mathrm{Al}^{3+}$ trocável $(\mathrm{M} \%)$, muito baixo $(0-35 \mathrm{~cm})$ ou nulo $(40-200 \mathrm{~cm})$, é normal para um Latossolo do Estado de São Paulo (Oliveira \& Menk, 1984) e se explica pelo pH que acima de 5,5 provoca a precipitação do alumínio.

Carbono e Nitrogênio: O teor de carbono é de $20,3 \mathrm{~g} \cdot \mathrm{kg}^{-1}$ em superfície $(0-35 \mathrm{~cm})$ e varia progressivamente de $12(40-60 \mathrm{~cm})$ até $6,7 \mathrm{~g} \cdot \mathrm{kg}^{-1}(160-200 \mathrm{~cm}$ de profundidade). $\mathrm{O}$ teor em carbono e nitrogênio enquadra-se na média encontrada para os Latossolos do Estado de São Paulo (Oliveira \& Menk, 1984) a qual varia de $20 \mathrm{~g} . \mathrm{kg}^{-1}$ (para o horizonte superficial), a $7 \mathrm{~g}^{-\mathrm{kg}^{-1}}$ (para os horizontes de profundidade). O nitrogênio ocorre em teor muito variável, de $1,5 \mathrm{~g} \cdot \mathrm{kg}^{-1}$ $(0-35 \mathrm{~cm})$ a $0,17 \mathrm{~g} \cdot \mathrm{Kg}^{-1}(160-200 \mathrm{~cm})$. A razão $\mathrm{C} / \mathrm{N}$ é decrescente com a profundidade (figura 34 ) apresentando valor mínimo de $13(160-200 \mathrm{~cm})$ e máximo de $39(0-35 \mathrm{~cm})$ que são considerados como valores médio a elevado para os oxisolos, refletindo baixo grau de humificação da matéria orgânica (Tomé Jr., 1997).

Composição em óxidos totais: Os teores em $\mathrm{Al}_{2} \mathrm{O}_{3}, \mathrm{Fe}_{2} \mathrm{O}_{3}$ e $\mathrm{TiO}_{2}$ aumentam em direção a profundidade, enquanto o teor $\mathrm{em} \mathrm{SiO}_{2}$ não apresenta variação correlacionada a profundidade, apresentando valor mínimo a $200 \mathrm{~cm}$ profundidade(15,1\%) (figura 35 ). 
Tabela 5: Composição química e granulométrica.

\begin{tabular}{|c|c|c|c|c|c|}
\hline & \multicolumn{5}{|c|}{ Profundidade $(\mathrm{cm})$} \\
\hline & $0-35$ & $40-60$ & $80-120$ & $100-120$ & $160-200$ \\
\hline Densidade real $\left(\mathrm{g} / \mathrm{cm}^{3}\right)$ & 2,67 & 2,50 & 2,44 & 2,50 & 2,56 \\
\hline $\mathrm{pH} \mathrm{H} \mathrm{H}_{2} \mathrm{O}$ & 4,5 & 5,6 & 5,6 & 5,1 & 5,2 \\
\hline $\mathrm{pH}$ em $\mathbf{K C l}$ & 3,8 & 5,0 & 5,1 & 4,6 & 4,7 \\
\hline $\mathrm{pH} \mathrm{em} \mathrm{CaCl}_{2}$ & 3,9 & 5,2 & 5,1 & 4,6 & 4,7 \\
\hline \multicolumn{6}{|c|}{ Cátions trocáveis(mmol kg-1 $)$} \\
\hline $\mathrm{Ca}^{2+}$ & 19 & 40 & 25 & 25 & 4 \\
\hline $\mathrm{Mg}^{2+}$ & 8 & 10 & 8 & 5 & 5 \\
\hline $\mathrm{K}^{+}$ & 1,2 & 0,3 & 0,2 & 0,2 & 0,2 \\
\hline $\mathrm{Al}^{3+}$ & 8 & 0 & 0 & 0 & 0 \\
\hline $\mathrm{H}^{+}+\mathrm{Al}^{3+}$ & 66 & 26 & 22 & 38 & 30 \\
\hline SB & 28,2 & 50,3 & 48,2 & 30,2 & 9,2 \\
\hline $\mathrm{T}$ & 94,2 & 76,3 & 70,2 & 68,2 & 39,2 \\
\hline $\mathrm{V}(\%)$ & 30 & 66 & 69 & 44 & 23 \\
\hline $\mathrm{M}(\%)$ & 22 & 0 & 0 & 0 & 0 \\
\hline $\mathrm{N}$ total $\left(\mathrm{g} \cdot \mathrm{kg}^{-1}\right)$ & 1,5 & 0,65 & 0,60 & 0,37 & 0,17 \\
\hline C total $\left(\mathrm{g} \cdot \mathrm{kg}^{-1}\right)$ & 20,34 & 12,01 & 10,26 & 9,97 & 6,74 \\
\hline $\mathrm{C} / \mathrm{N}$ & 13,56 & 18,84 & 17,10 & 27,17 & 39,19 \\
\hline \multicolumn{6}{|l|}{ Óxidos totais (g. $\left.\mathrm{Kg}^{-1}\right)$} \\
\hline $\mathrm{SiO}_{2}$ & 165,0 & 175,0 & 158,0 & 180,0 & 151,0 \\
\hline $\mathrm{Al}_{2} \mathrm{O}_{3}$ & 176,4 & 198,9 & 199,9 & 209,1 & 207,0 \\
\hline $\mathrm{Fe}_{2} \mathrm{O}_{3}$ & 178,8 & 190,2 & 194,1 & 209,4 & 203,8 \\
\hline $\mathrm{TiO}_{2}$ & 34,6 & 32,3 & 36,0 & 37,9 & 37,5 \\
\hline $\mathrm{MnO}$ & 1,0 & 0,60 & 0,70 & 0,70 & 0,60 \\
\hline $\mathrm{Ki}$ & 1,59 & 1,50 & 1,34 & 1,46 & 1,24 \\
\hline $\mathrm{Kr}$ & 0,96 & 0,93 & 0,83 & 0,89 & 0,76 \\
\hline \multicolumn{6}{|l|}{ Granulometria (g. $\mathrm{Kg}^{-1}$ ) } \\
\hline Areia total * & 160 & 150 & 230 & 210 & 230 \\
\hline Silte & 150 & 120 & 80 & 80 & 100 \\
\hline Argila & 690 & 730 & 690 & 710 & 670 \\
\hline
\end{tabular}

(SB) soma de bases, (T) capacidade de troca catiônica, (M) alumínio trocável $\left(\mathrm{Al}^{3+} / \mathrm{Al}^{3+}\right.$ $+\mathrm{S}), \mathrm{H}^{+}+\mathrm{Al}^{3+}$ solução de acetato de cálcio $1 \mathrm{~N} \mathrm{a} \mathrm{pH}=7,0$, 


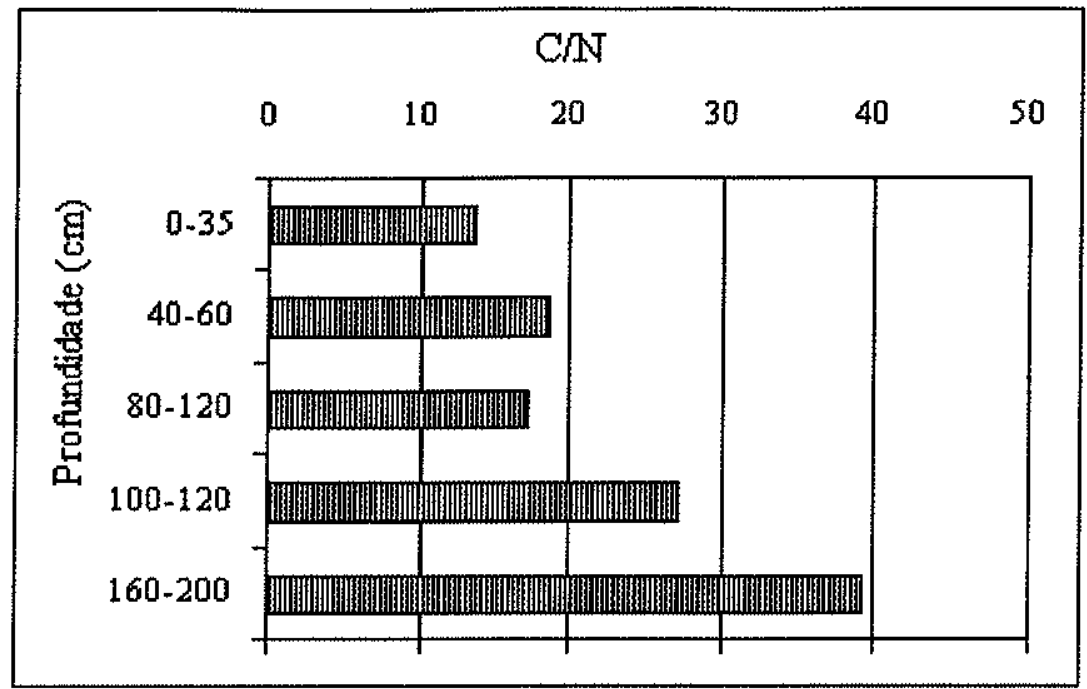

Figura 34: Variação da razão $\mathrm{C} / \mathrm{N}$.

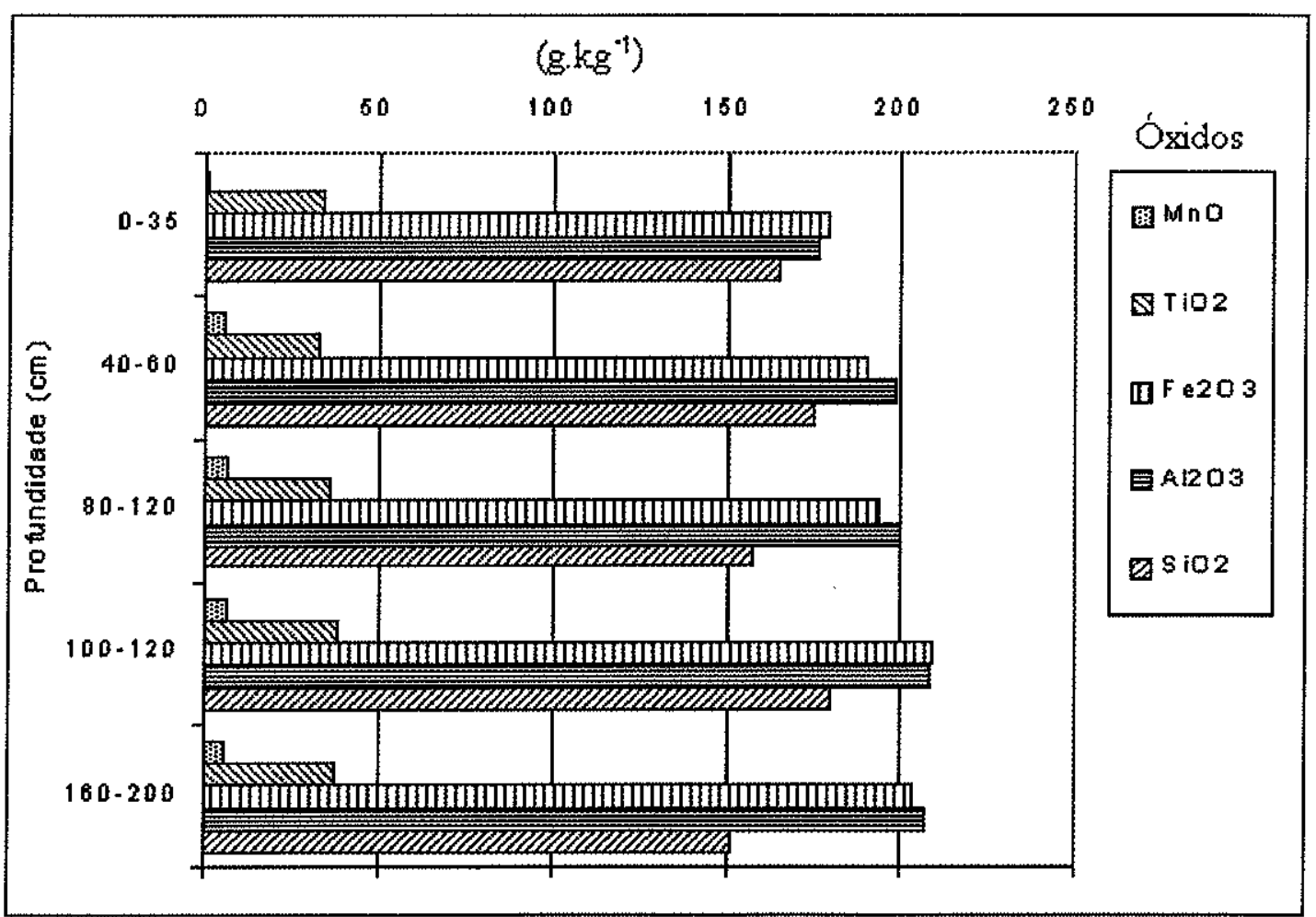

Figura 35: Composição em óxidos totais. 


\subsection{Caracterização mineralógica do Latossolo}

Os difratogramas (figuras 36,37 e 38 ) de raio $\mathrm{X}$ obtidos para a fração argila deferrificada mostram a predominância de caolinita e de gibbsita e, em traços de argilominerais interestratificados, identificados como clorita-vermiculita. Estes difratogramas mostram a homogeneidade da fração argila do perfil do Latossolo.
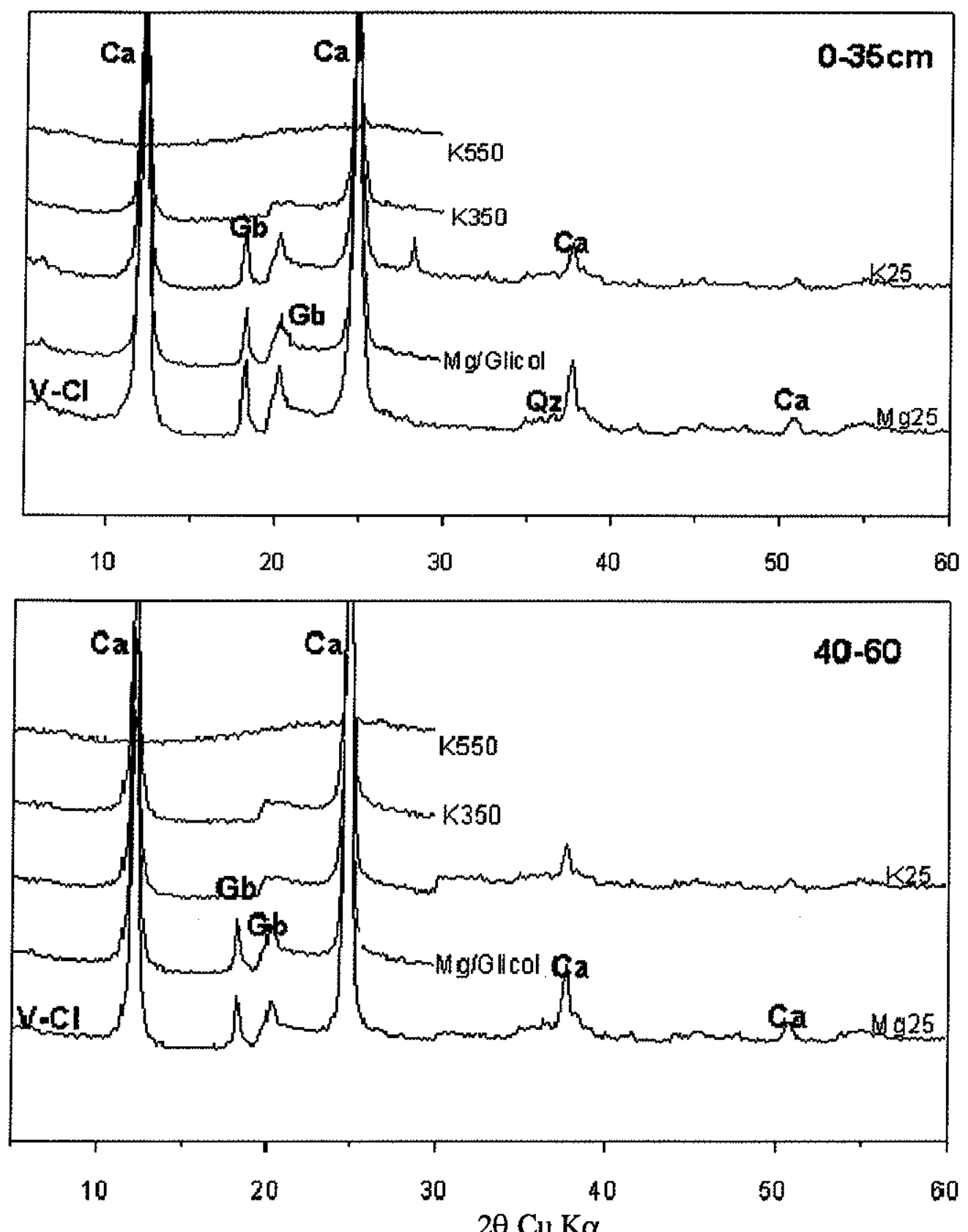

Figura 36: Difratogramas de raio $\mathrm{X}$ da fração argila. $\mathrm{Ca}=$ caolinita; $\mathrm{V}-\mathrm{Cl}=$ clorita/vermiculita; $\mathrm{Gb}=$ gibbsita. $\mathrm{Mg} /$ glicol amostra glicolada; K350 e K550 amostras saturadas em potássio com aquecimento a $350^{\circ}$ e $550^{\circ} \mathrm{C}$. 

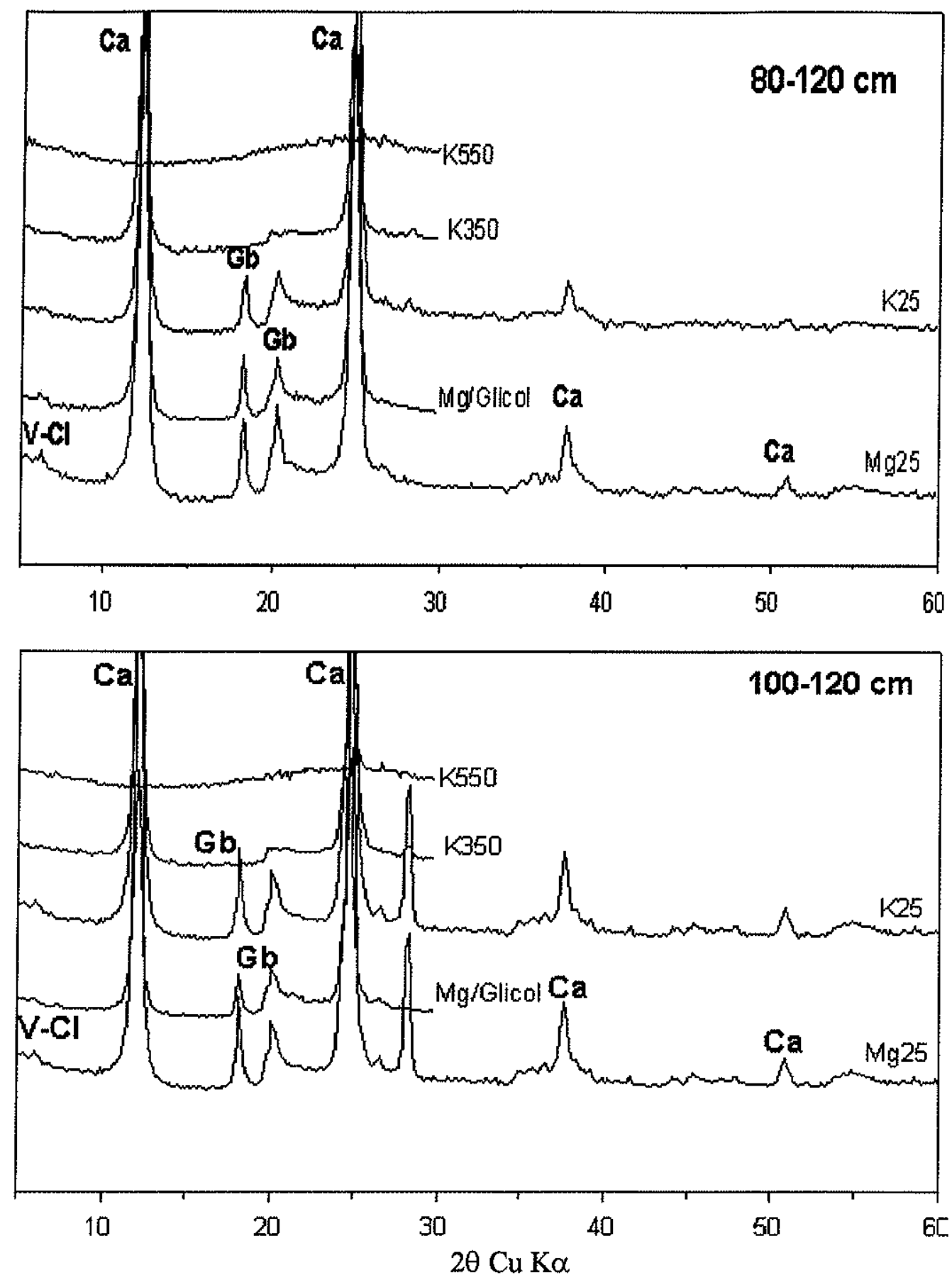

Figura 37: Difratogramas de raio $\mathrm{X}$ da fração argila. $\mathrm{Ca}=$ caolinita; $\mathrm{V}-\mathrm{Cl}=$ clorita/vermiculita; $\mathrm{Gb}=$ gibbsita $\mathrm{Mg}$ /glicol amostra glicolada; K350 e K550 amostras saturadas em potássio com aquecimento a $350^{\circ}$ e $550^{\circ} \mathrm{C}$. 


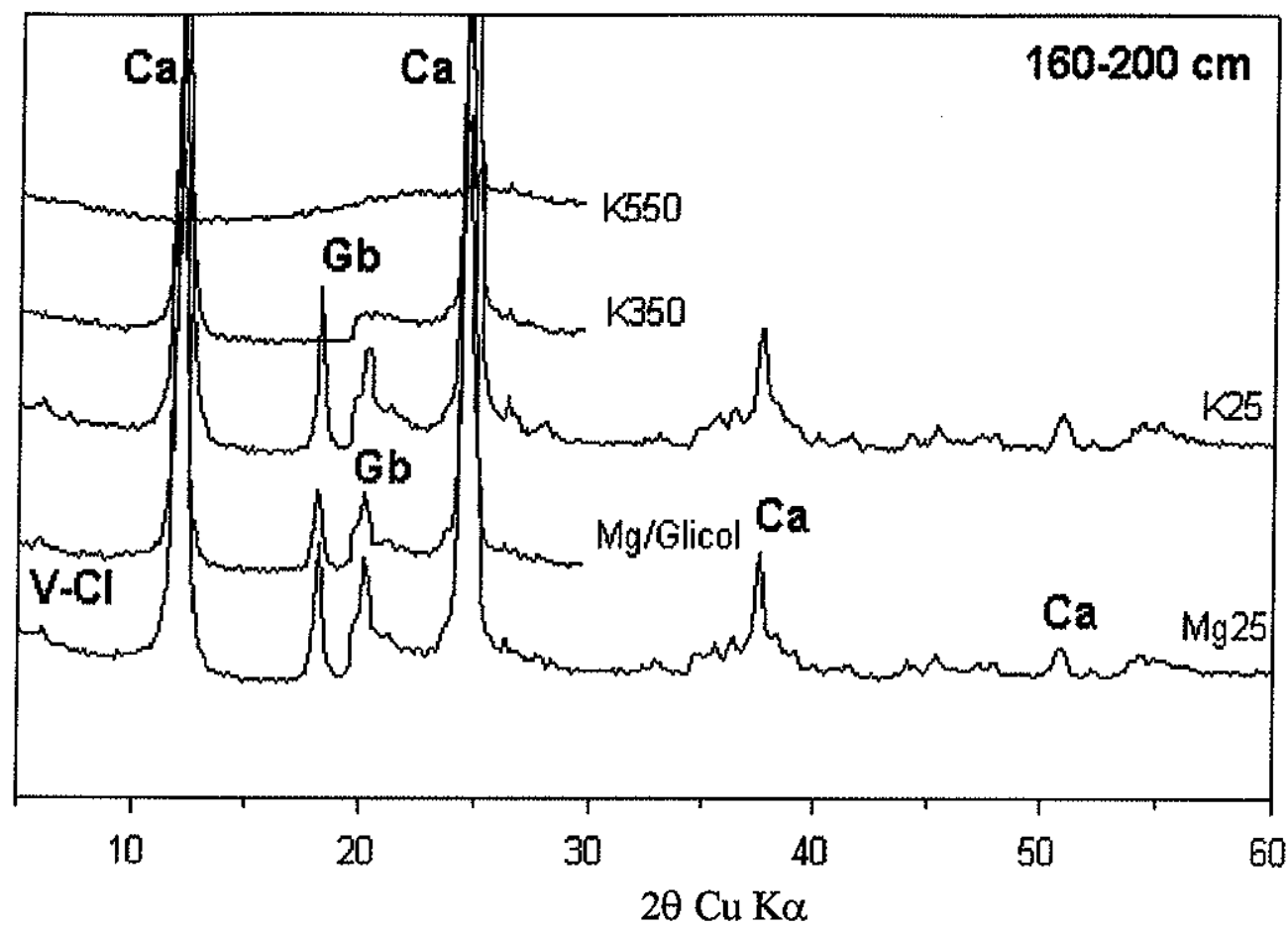

Figura 38: Difratograma de raio $\mathrm{X}$ da fração argila. $\mathrm{Ca}=$ caolinita; $\mathrm{V}-\mathrm{Cl}=$ clorita/vermiculita; $\mathrm{Gb}=$ gibbsita. $\mathrm{Mg}$ /glicol amostra glicolada; K350 e K550 amostras saturadas em potássio com aquecimento a $350^{\circ}$ e $550^{\circ} \mathrm{C}$.

\subsection{Caracterização micromorfológica das pelotas}

Foram descritas 7 seções delgadas das pelotas produzidas pelos cupins no campo e no laboratório (figuras 39 e 40). Foram estudadas as pelotas produzidas por cupins nas seguintes condições:

- Pelotas de Cornitermes e Syntermes produzidas no campo.

- Pelotas de Cornitermes e Syntermes produzidas no laboratório com amostras de Latossolo peneirado.

- Pelotas de Cornitermes produzidas no laboratório com amostras de Latossolo desagregado ou com argila cinza.

As pelotas produzidas no campo e no laboratório (com amostras de Latossolo peneirado) tanto pela atividade de Cornitermes como de Syntermes apresentam subestruturas formadas por microagregados menores aglutinados por plasma argiloso (figuras 39, 40). As subestruturas apresentam diâmetro em torno de $100 \mu \mathrm{m}$ 
As pelotas produzidas por Cornitermes com amostras de Latossolo desagregado ou com argila cinza, são pelotas compactas, sem subestrutura (figura 42: B, C, D)

$O$ arranjo entre as pelotas é por empilhamento com uma forte coalescência. $O$ esqueleto apresenta triagem granulométrica principalmente nos grãos de quartzo com diâmetro entre $100 \mu \mathrm{m}$ e $300 \mu \mathrm{m}$. A porosidade intragregado é forte, policôncava, interconectada e de dimensão variando de 10 a $2000 \mu \mathrm{m}$. 

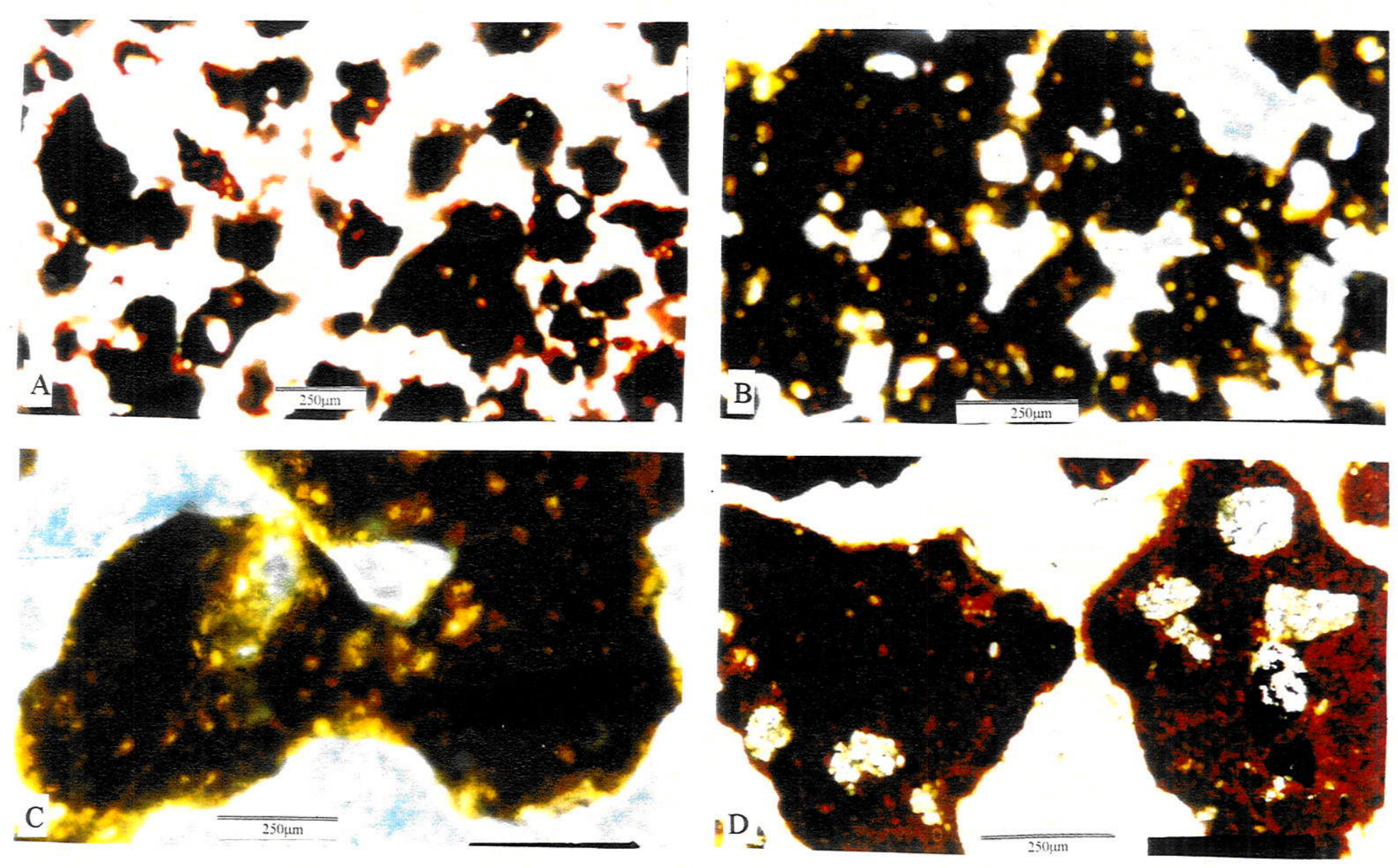

Figura 39: Microscopia ótica.(A e D luz normal, B e C luz polarizada). (A) Pelotas de Cornitermes produzidas ne campo (diâmetro de 0,1 a 0,8mm).(B) Pelotas de Cornitermes produzidas no॰laboratório com argila cinza. Nota-se um empilhamento composto das pelotas (C) Pelotas de Cornitermes produzidas no laboratório com argila cinza. Detalhe da junção entre duas pelotas com plasma argiloso (D) Pelotas de Cornitermes produzidas no laboratório com amostras de Latossolo desagregado. 

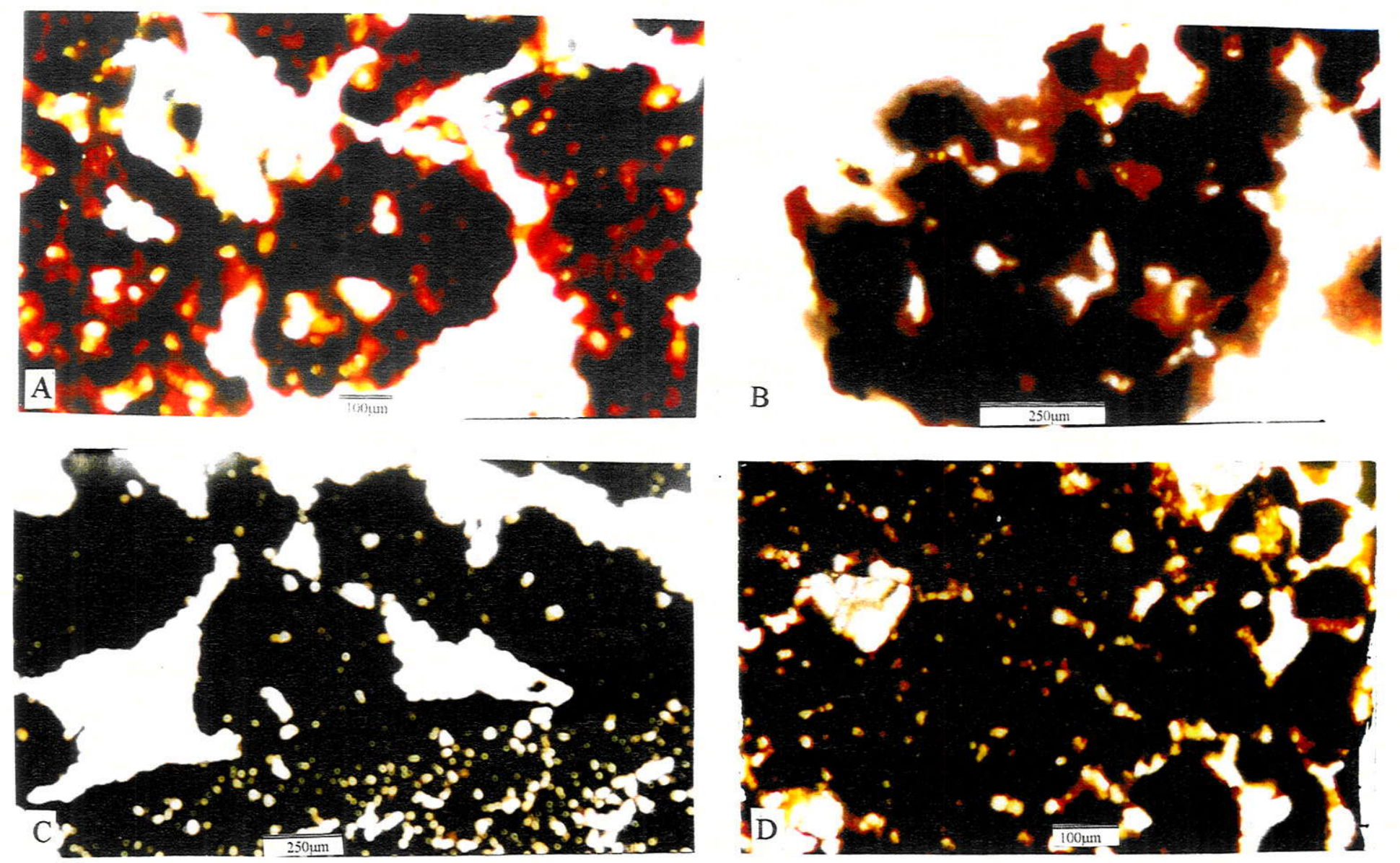

Figura 40: Microscopia ótica (luz polarizada) (A) Pelotas de Cornitermes produzidas no laboratório com amostras de Latossolo peneirado. Nota-se subestrutura microagregada (diâmetro $<100 \mu \mathrm{m}$ ). (B) (C) e (D) Pelotas de Syntermes produzidas com amostras de Latossolo peneirado. Em (B) pelota com subestrutura (diâmetro em torno $100 \mu \mathrm{m}$ ) (C) Transição entre a parte superior do terrário e as pelotas empacotadas. (D) Contato entre $\mathrm{o}$ terrário (parte esquerda da lâmina) e microagregados empacotados. 


\subsection{Observação das pelotas no Microscópio Eletrônico de Varredura (MEV)}

Encontrou-se pelotas com subestruturas tanto produtos da atividade de Cornitermes quanto de Syntermes. As amostras de Latossolo desagregado apresenta maior incidência de pelotas sem subestrutura. Ao contrário, as pelotas produzidas a partir de amostras de Latossolo peneirado e as pelotas produzidas no campo apresentam predomínio de pelotas com subestrutura. São descritas na superficie das pelotas, marcas de mandíbulas e de peças bucais (figura 42: B, C; figura 43: $\mathrm{E}$, F; figura 44: E, F; figura 45: E, F). Na figura 41, é apresentada as morfologia das peças bucais e mandibulares que os operários utilizam para remoção do material do solo e confecção das pelotas.

Tramas de hifas de fungos (figura 42: D, F) foram encontradas sobre a superficie de pelotas produzidas no campo.

Os espectros de EDS revelam composição de caolinita e óxidos de ferro na superficie das pelotas, similares aos microagregados do Latossolo.
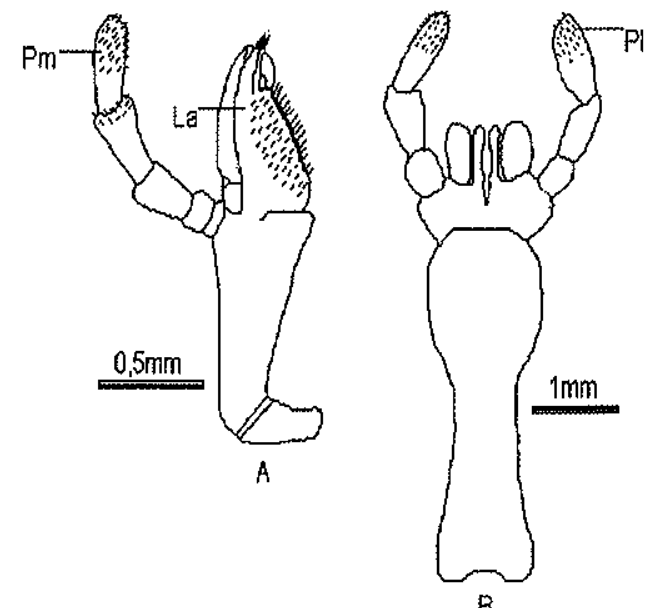

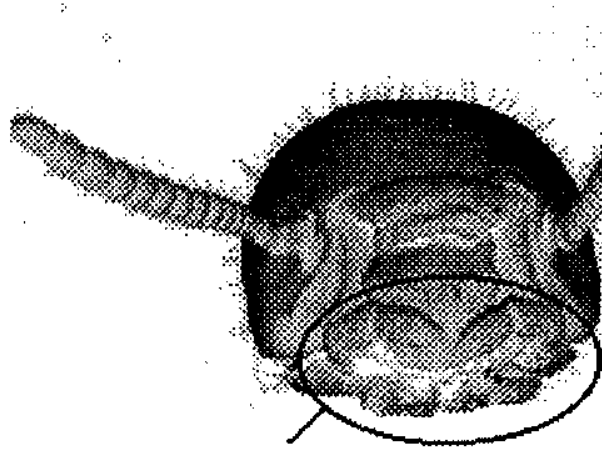

peças bucais utilizadas na produçã̃o das pelotas

Comparaçăo de um maxilar (A)e um labium(B) indicando as estruturas (Pm) palpo maxilar, (La) lacinia, (Pl) palpo labial.

Figura 41: Peças bucais e mandibulares de operários de cupins utilizadas para remoção de material do solo e produção das pelotas. 

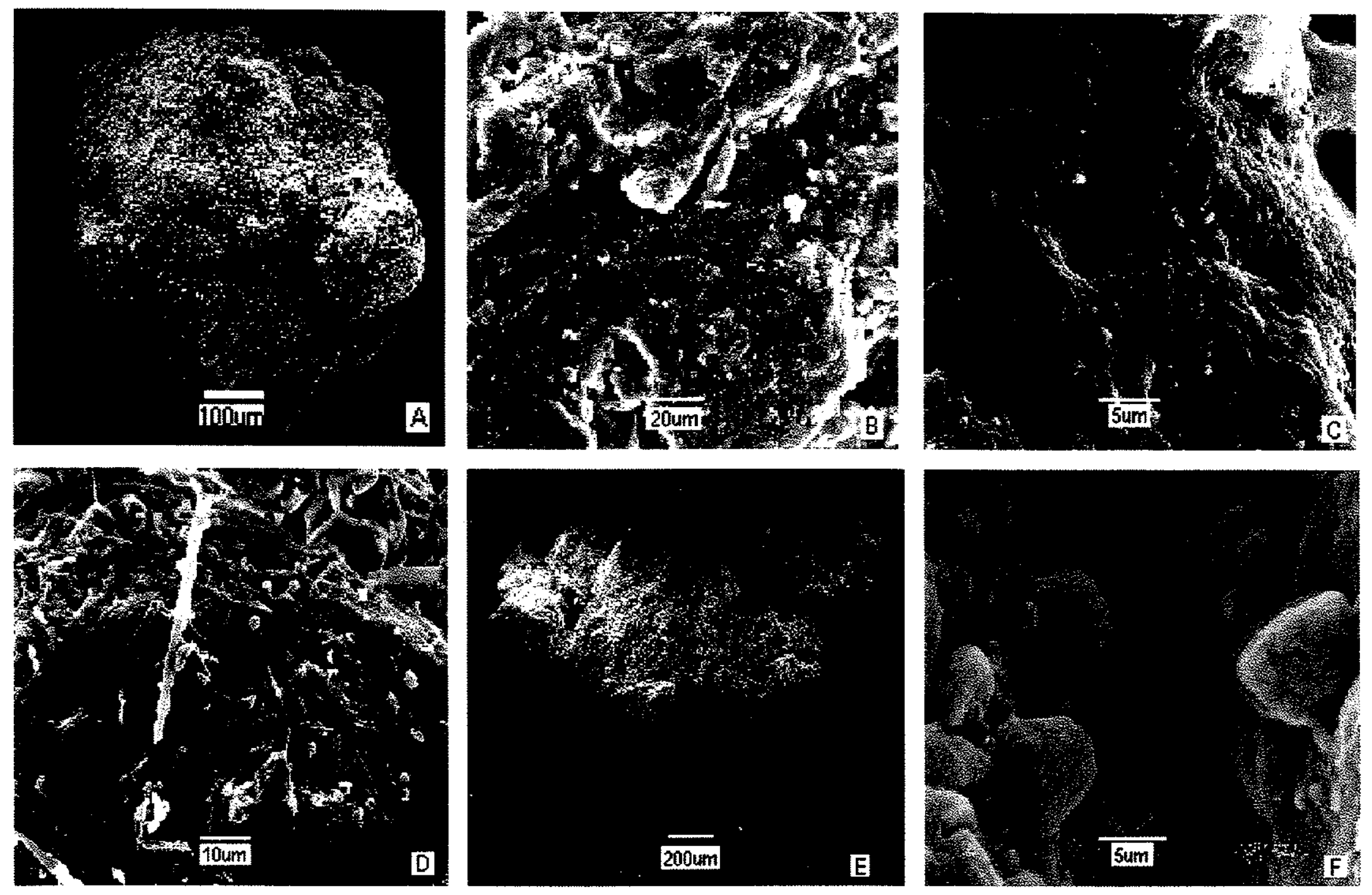

Figura 42: Microscopia Eletrônica de Varredura. (A) a (F) Pelotas de Cornitermes produzidas no campo. (A) Pelota sem subestrutura (B) Detalhe da superficie da amostra (A) com estrias alongadas (moldes de mandíbula) (C) Detalhe da superficie de uma pelota com poros circulares abundantes, interpretados como marcas de pêlos e espinhos bucais (presentes nos palpos mandibulares e maxilares) (D) Superficie de uma pelota coberta por uma rede de hifas de fungos (E) Pelota com subestrutura (F) Detalhe da superficie da pelota (E) onde ocorrem hifas de fungos promovendo a agregação das subpartículas da pelota. 

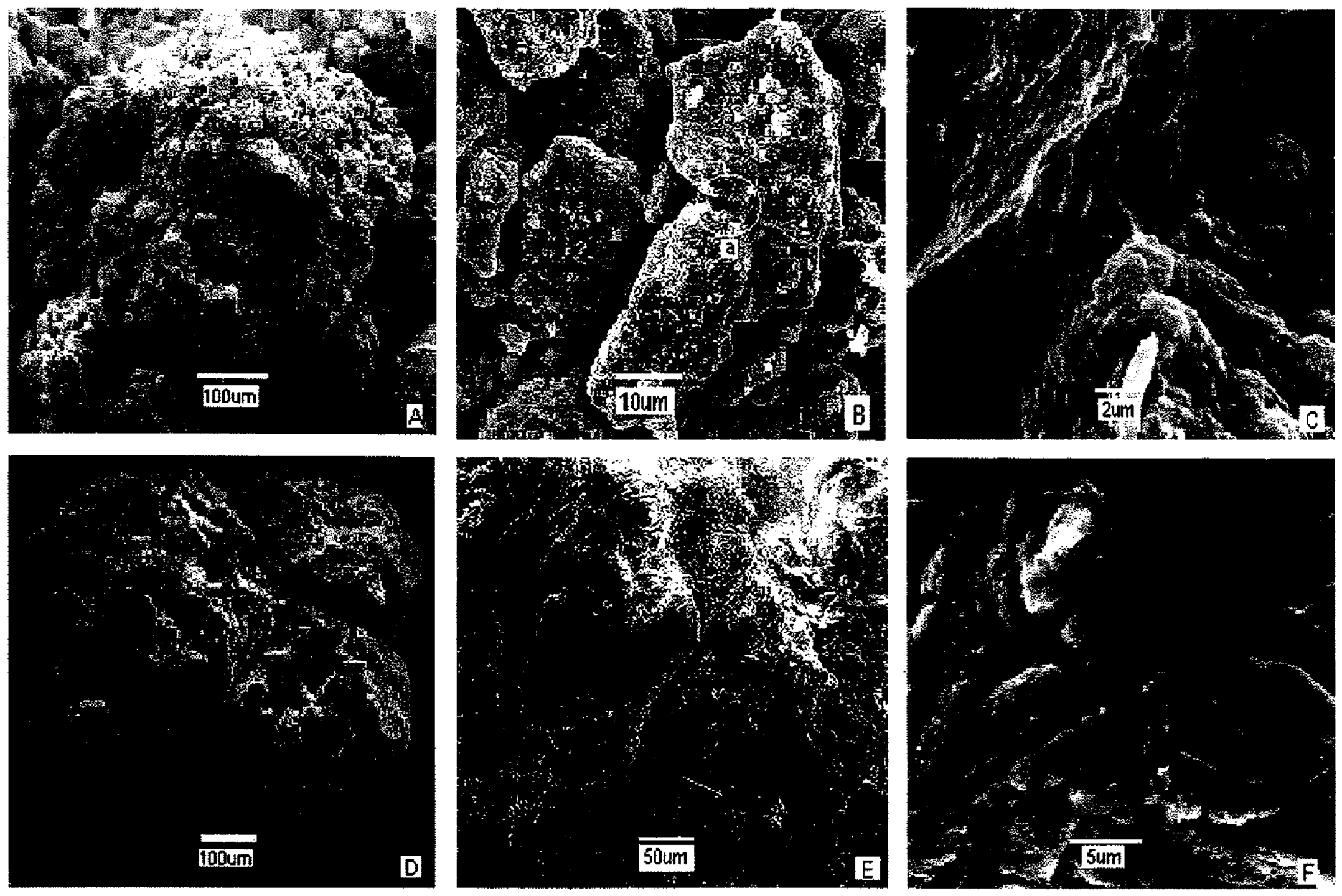

Figura 43: Microscopia Eletrônica de Varredura. Pelotas de Cornitermes produzidas no laboratório. (A) a (C) pelotas produzidas no laboratório com amostras de Latossolo peneirado (D) a (F) pelotas produzidas no laboratório com amostras de Latossolo desagregado. (C) detalhe (a) da Figura (B). 

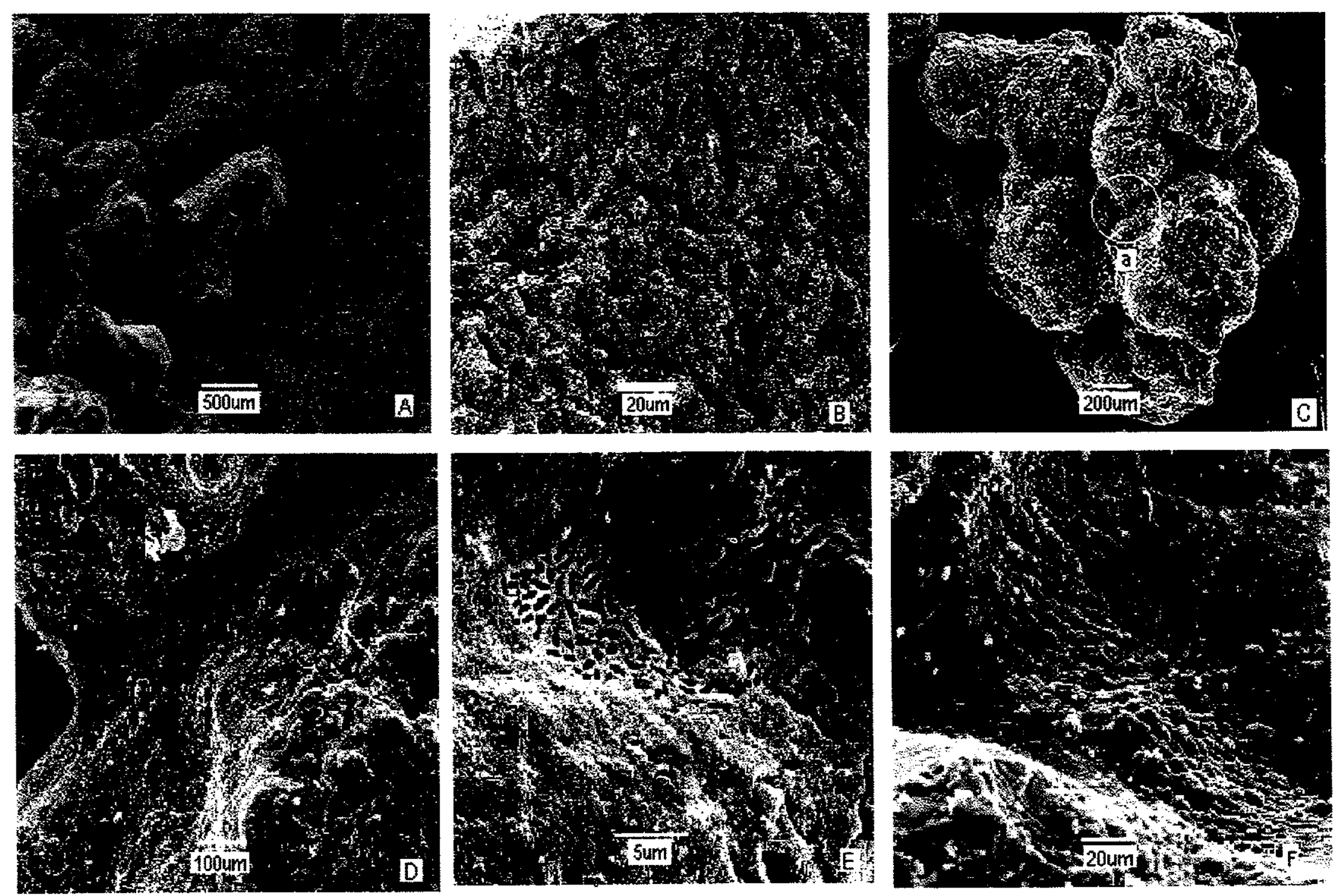

Figura 44: Microscopia Eletrônica de Varredura. Pelotas de Cornitermes produzidas no laboratório com argila cinza. (A) Arranjo entre pelotas sem subestrutura (B) Detalhe da parede interna de um canal com marcas de remoção de argila. Trata-se de sulcos alongados de $10 \mu \mathrm{m}$ de comprimento (C) Pelota com subestrutura (D) Detalhe (a) da pelota (C) ilustrando o recobrimento argiloso sobre a superficie da pelota (E) Detalhe da superficie de uma pelota mostrando a trama de microporos, interpretados como marcas de pelos e espinhos bucais (presentes nos palpos mandibulares e maxilares) (F) Detalhe da superficie de uma pelota mostrando marcas e sulcos alongados. 

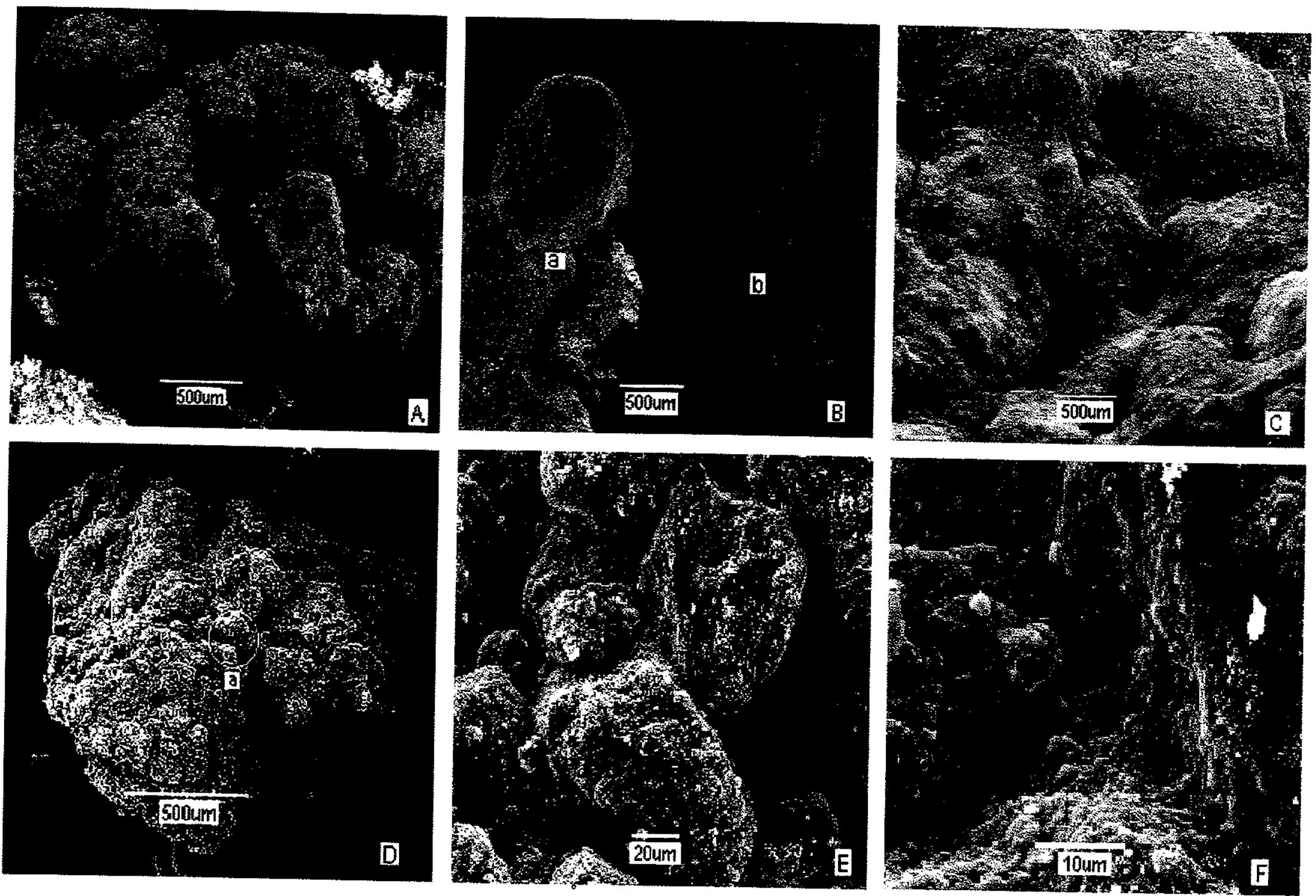

Figura 45: Microscopia Eletrônica de Varredura. (A) a (F) Pelotas de Syntermes. (A) a (C) pelotas produzidas no campo (A) Pelota com subestrutura (B) Pelotas sem subestrutura (interior de um canal). Em (a) pelota ovoidal solta e em (b) pelota amassada na parede do canal. (C) Pelotas amassadas e sobrepostas formando o revestimento interno de um canal (D) a (F) Pelotas de Syntermes produzidas no laboratório com amostras de Latossolo peneirado (D) Pelotas do tipo composta com subestrutura (E) Detalhe (a) da pelota (D) ilustrando a subestrutura (F) Detalhe da pelota (E) ilustrando microporos na junção das subpartículas. 


\subsection{Identificação e caracterização bionômica dos cupins}

A análise teve como objetivo de identificar os cupins até o taxa de gênero e levantar dados morfométricos relativos à abertura máxima das mandíbulas dos operários, visto que, sendo um atributo específico para cada espécie, pode representar um parâmetro importante para a correlação entre a abertura máxima das mandíbulas e o tamanho das pelotas produzidas.

Os dois gêneros estudados, pertencem a Subfamília Nasutitermitinae, que nas regiões tropicais é representada por 19 gêneros e 185 espécies (Araújo,1970). A caraterística marcante da subfamília relaciona-se a diversidade de material utilizado e arquitetura dos ninhos.

Segue breve resumo das principais características de cada gênero estudado:

Gênero Cornitermes (Wasman, 1897) - Este gênero apresenta 14 espécies, que tem como característica construir grandes ninhos, em vastos espaços livres. Ocorrem desde a Costa Rica até a Argentina. Araújo cita que $C$. cumulans é talvez a mais comum e a mais bem sucedida espécie que ocupa áreas de pastagem, culturas e savanas da região sudeste e centro-oeste do Brasil. Grassé (1984) descreveu que C. cumulans ocupa solos com alta proporção em argila, desenvolvendo ninhos hipógeos nas primeiras fases de crescimento da colônia a partir da qual se evoluem para ninhos epígeos com grande diferenciação interna. Os cupins estudados (figura 46A) representantes deste gênero provém do Latossolo Roxo de Iracemápolis.

Gênero Syntermes (Holmgren,1910) - Apresenta 23 espécies restritas à América do Sul e tem como característica construções conspícuas, hipógeas, podendo atingir até 3 metros de altura e de 7 a 8 metros de diâmetro (Grassé, 1984).

O material retirado da escavação é disposto fora do ninho, na superficie do solo, formando montículos terrosos de até $0,7 \mathrm{~m}$ de altura (Grassé, 1984). As galerias atingem profundidade de até 3 metros e ocupam preferencialmente solos argilosos. Apresentam hábitos cortadores de folhas carreando material para o fundo do ninho, geralmente encontrados ao longo das galerias e câmaras subterrâneas (Araújo, 1970). Os indivíduos adultos deste gênero são grandes podendo atingir $2 \mathrm{~cm}$ de comprimento $O$ s cupins estudados estudados foram coletados sobre um Latossolo Roxo de Ribeirão Preto (figura 46B).

A fabricação de pelotas de uma colônia é realizada exclusivamente por operários e o tamanho das pelotas relaciona-se a dimensão bucal destes operários. Obviamente, ocorre variação no tamanho dos indivíduos, das mandíbulas (tabela 6) e consequentemente das pelotas produzidas. Outro fator que deve ser considerado, relaciona-se ao fato de que em uma colonia 
todos os operários participam da atividade, tanto jovens pequenos e despigmentados, como adultos em tamanhos máximos (Hedlund \& Henderson, 1999).

$\mathrm{Na}$ experimentação de laboratório foram introduzidos nos terrários somente indivíduos adultos, e o tamanho máximo de pelotas que a colônia pode produzir.
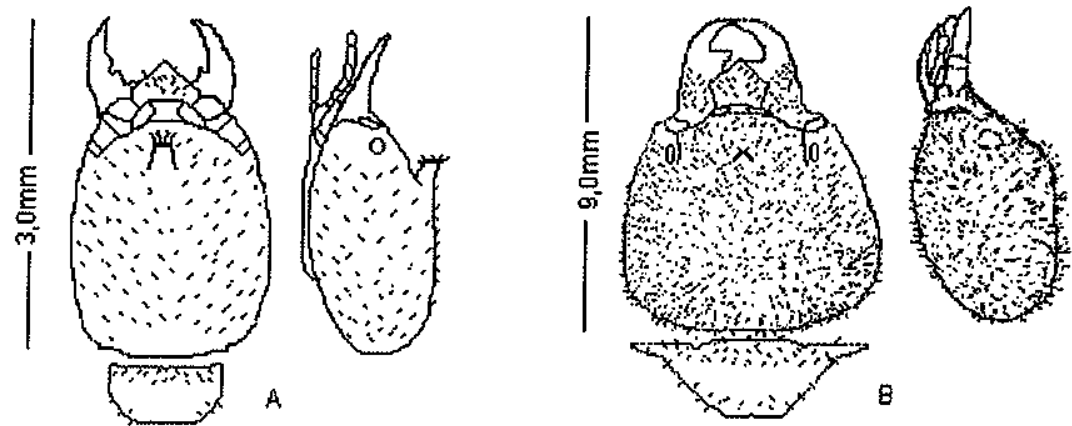

Termitidae:Nasutitermitinae, Detalhe cabeça de soldados. (A) Cornitermes cumulans;(B) Syntermes sp.

Figura 46: Morfologia da cabeça de soldados dos gêneros Cornitermes e Syntermes dos cupins estudados. A: desenho do autor .B: extraído de Constantino (1999).

Tabela 6: Morfometria de operários adultos de Cornitermes e Syntermes, envolvidos nos experimentos em laboratório.

\begin{tabular}{|c|c|c|c|}
\hline \multirow{4}{*}{ Comitermes } & $\begin{array}{c}\text { Comprimento total } \\
(\mathrm{mm})\end{array}$ & $\begin{array}{c}\text { Comprimento cabeça } \\
(\mathrm{mm})\end{array}$ & $\begin{array}{c}\text { Largura cabeça } \\
(\mathrm{mm})\end{array}$ \\
\cline { 2 - 4 } & 5,1 & 2,0 & 1,6 \\
\cline { 2 - 4 } & 5,0 & 2,0 & 1,6 \\
\cline { 2 - 4 } & 5,3 & 2,0 & 1,6 \\
\cline { 2 - 4 } & 5,4 & 2,0 & 1,6 \\
\hline Média & 4,3 & 2,0 & 1,6 \\
\hline \multirow{5}{*}{ Syntermes } & 4,2 & 2,0 & 1,6 \\
\cline { 2 - 4 } & $\mathbf{4 , 9}$ & $\mathbf{2 , 0}$ & $\mathbf{1 , 6}$ \\
\cline { 2 - 4 } & 10,5 & 3,5 & 3,2 \\
\cline { 2 - 4 } & 10,5 & 3,5 & 3,2 \\
\cline { 2 - 4 } & 10,5 & 3,5 & 3,2 \\
\cline { 2 - 4 } & 10,5 & 3,5 & 3,2 \\
\hline \multirow{4}{*}{ Média } & 10,5 & 3,5 & 3,2 \\
\hline
\end{tabular}

Operários adultos apresentam morfometria bem contrastada entre duas espécies. Para fabricar uma pelota, isto é, para raspar e/ou cortar material do solo, o operário utiliza suas mandíbulas, podendo abri-los até a largura máxima, que corresponde a largura da cabeça. A largura da cabeça fornece assim o diâmetro máximo das pelotas possíveis de ser produzida por uma espécie. 


\subsection{Experimento de produção de pelotas no laboratório}

\subsubsection{Desagregação mecânica. dos microagregados}

Para a desagregação dos microagregados, não foi utilizado nenhum tipo de dispersante químico, devido a necessidade de se manter as caraterísticas originais dos argilominerais. A desagregação ultrasônica apresentou eficiência de $85 \%$ (Figura 10), porém com o incoveniente de possibilitar a desagregação de pequena quantidade de amostras em cada processamento (Figura 47). Dos testes realizados, a trituração no liquidificador (figura 9) mostrou-se o método mais eficiente. A eficiência na desagregação foi de 85 a 95\% (figuras 10 e 48).

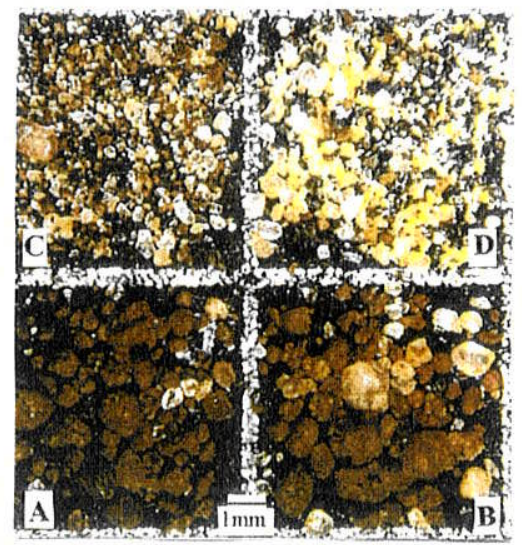

Figura 47: Observação em lupa binocular, luz incidente. Aspecto das amostras de Latossolo após desagregação mecânica ultra-sônica. Exposição a tempo variado. A: 5mn; B: $15 \mathrm{mn}$; C:40mn; D: $60 \mathrm{mn}$.

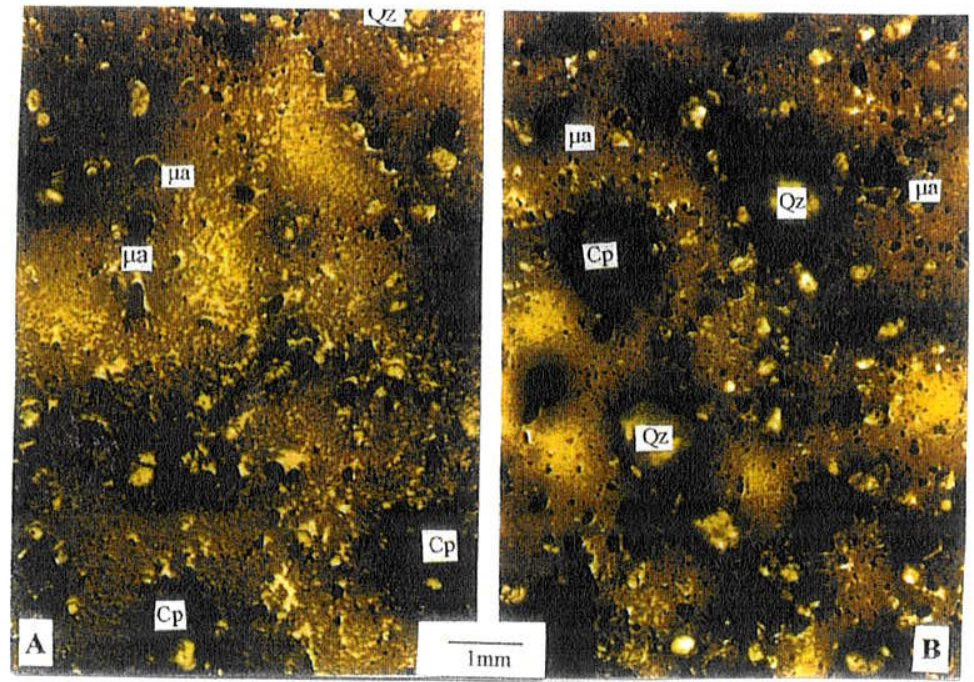

Figura 48: Observação em lupa binocular, luz incidente. Amostras de Latossolo após desagregação mecânica no liquidificador. Qz: grão de quartzo, Cp: concentração de plasma argiloso (floculação) $\mu \mathrm{a}$ : microagregados (inteiros ou fragmentados). 


\subsection{Morfometria das pelotas produzidas no campo e no laboratório}

Estão apresentadas as pelotas produzidas no campo e no laboratório (figura 51) e gráficos de morfometria com as razões $\mathrm{B} / \mathrm{A}$ e $\mathrm{C} / \mathrm{D}$ (figura 50), de arredondamento e esfericidade (figuras 51 e 52$)$.

As pelotas produzidas com amostras de Latossolo peneirado apresentaram subestrutura e superficie rugosa similar aos microagregados com subestrutura do perfil do Latossolo. (figuras 18A, 19E).

Os índices de esfericidade e arredondamento indicam predominância de pelotas com alta esfericidade bidimensional com formas esferoidais/subesferoidais (índices $\mathrm{B} / \mathrm{A}$ e C/B equidimensionais). Para arredondamento e esfericidade das pelotas, ocorrem pelotas com contornos entre subangulosos (índice 0,3) a bem arredondados (índice 0,9) com predomínio de formas subangulosas.

As dimensões das pelotas (diâmetros máximos e mínimos) (Tabela 7), indicam que os pelotas de Cornitermes assim como os de Syntermes apresentam similaridades entre as pelotas produzidas no campo e no laboratório, apresentando variação entre 0,3 a $1,4 \mathrm{~mm}$ para Cornitermes e entre 0,9 a $2,8 \mathrm{~mm}$ para Syntermes considerando-se respectivamente os menores e maiores valores do diâmetro médio das pelotas.

Tabela 7: Medidas dos diâmetros médios máximos (eixo A) e mínimos (eixo C) das pelotas de cupins de campo e de laboratório.

\begin{tabular}{|l|l|l|}
\hline \multicolumn{1}{|c|}{ Amostra } & $\begin{array}{c}\text { Diâmetro médio } \\
\text { mímimo } \\
(\mathrm{mm})\end{array}$ & $\begin{array}{l}\text { Diâmetro médio } \\
\text { máximo } \\
(\mathrm{mm})\end{array}$ \\
\hline $\begin{array}{l}\text { Pelotas de Cornitermes produzidas no } \\
\text { campo }\end{array}$ & $0,86 \pm 0,20$ & $1,14 \pm 0,25$ \\
\hline $\begin{array}{l}\text { Pelotas de Cornitermes produzidas no } \\
\text { laboratório com amostras de Latossolo } \\
\text { desagregado }\end{array}$ & $0,60 \pm 0,18$ & $0,97 \pm 0,19$ \\
\hline $\begin{array}{l}\text { Pelotas de Cornitermes produzidas no } \\
\text { laboratório com amostras de Latossolo } \\
\text { peneirado }\end{array}$ & $0,78 \pm 0,21$ & $1,14 \pm 0,24$ \\
\hline $\begin{array}{l}\text { Pelotas de Cornitermes produzidas no } \\
\text { laboratório com amostras de argila cinza }\end{array}$ & $0,49 \pm 0,9$ & $0,84 \pm 0,19$ \\
\hline $\begin{array}{l}\text { Pelotas de Syntermes produzidas no campo } \\
\text { Pelotas de Syntermes produzidas no } \\
\text { laboratório com amostras de } \\
\text { Latossolo peneirado }\end{array}$ & $1,26 \pm 0,34$ & $2,35 \pm 0,48$ \\
\hline
\end{tabular}



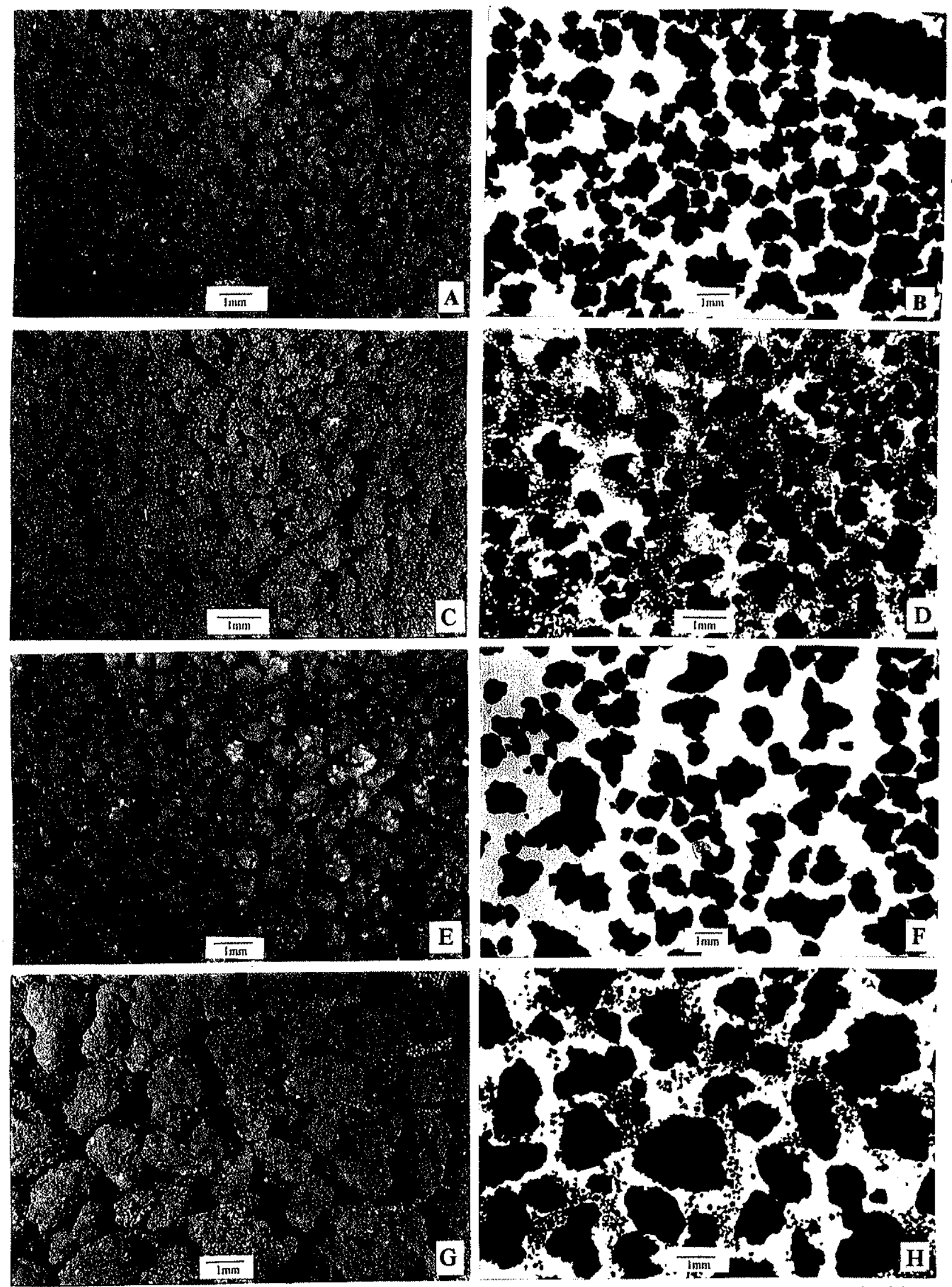

Figura 49: (Lupa binocular, luz incidente) (A) pelotas coalescentes do campo produzidas por Cornitermes (B) imagem anterior sob luz transmitida (C) pelotas de Cornitermes produzidas no laboratório com Latossolo peneirado, predomina tipo com subestrutura (D) imagem anterior sob luz transmitida, onde observa-se distribuição das partículas menores que compõem a subestrutura (E) pelotas de Cornitermes produzidas no laboratório com latossolo desagregado (F) imagem anterior sob luz transmitida $(G)$ pelotas de Syntermes produzidas no laboratório com latossolo peneirado $(H)$ imagem anterior sob luz transmitida. 
A relação entre a razão morfométrica $\mathrm{B} / \mathrm{A}$ e $\mathrm{C} / \mathrm{B}$ (tabela 8 , figura 50 ) para as pelotas confirma o predomínio de forma esferoidal para os microagregados analisados.

A caracterização morfoscópica das pelotas apresenta forte variação no arredondamento com índice variando de 0,1 (anguloso) a 0,9 (arredondado) para as pelotas produzidas por Cornitermes e Syntermes, no campo e no laboratório (figura 51). A esfericidade (figura 52) ocorre mais homogênea entre 0,5 (subanguloso) a 0,9 (arredondado).

Tabela 8: Razão morfométrica B/A e C/B para os microagregados.

\begin{tabular}{|c|c|c|}
\hline \multirow[b]{2}{*}{ Pelotas } & \multicolumn{2}{|c|}{ Razão morfométrica dos eixos } \\
\hline & $\mathbf{B} / \mathbf{A}$ & $\mathbf{C} / \mathbf{B}$ \\
\hline Pelotas de Cornitermes produzidas no campo & $0,80 \pm 0,14$ & $0,77 \pm 0,13$ \\
\hline 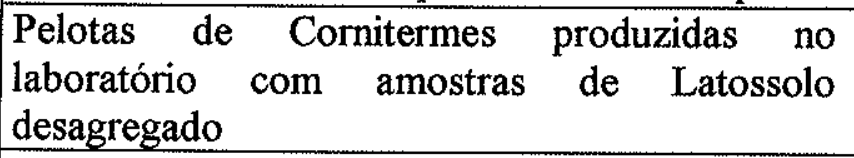 & $0,70 \pm 0,19$ & $0,83 \pm 0,14$ \\
\hline $\begin{array}{l}\text { Pelotas de Cornitermes produzidas no } \\
\text { laboratório com amostras de Latossolo } \\
\text { peneirado }\end{array}$ & $0,75 \pm 0,14$ & $0,74 \pm 0,18$ \\
\hline $\begin{array}{l}\text { Pelotas de Cornitermes produzidas no } \\
\text { laboratório com amostras de argila cinza }\end{array}$ & $0,79 \pm 0,16$ & $0,79 \pm 0,14$ \\
\hline Pelotas de Syntermes produzidas no campo & $0,89 \pm 0,14$ & $0,85 \pm 0,12$ \\
\hline $\begin{array}{l}\text { Pelotas de Syntermes produzidas no } \\
\text { laboratório com amostras de Latossolo } \\
\text { peneirado }\end{array}$ & $0,74 \pm 0,13$ & $0,83 \pm 0,14$ \\
\hline
\end{tabular}

Observação: $\mathrm{B} / \mathrm{A}$ e $\mathrm{C} / \mathrm{B}$ razões morfométricas definidas no ítem 4.2 .5 

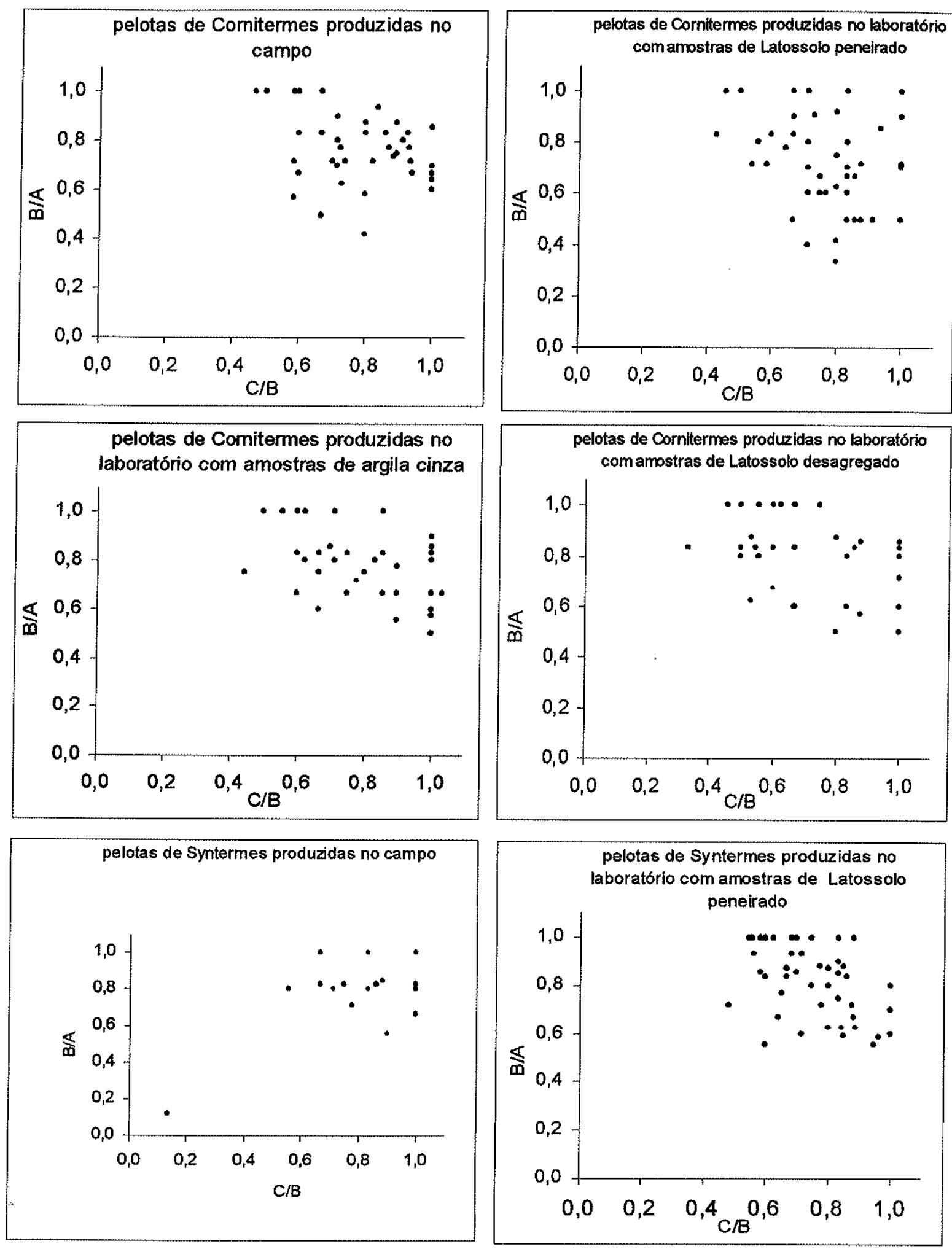

Figura 50: Morfometria ilustrada pelas razões $\mathrm{B} / \mathrm{A}$ e $\mathrm{C} / \mathrm{B}$ das pelotas produzidas no campo e no laboratório. 

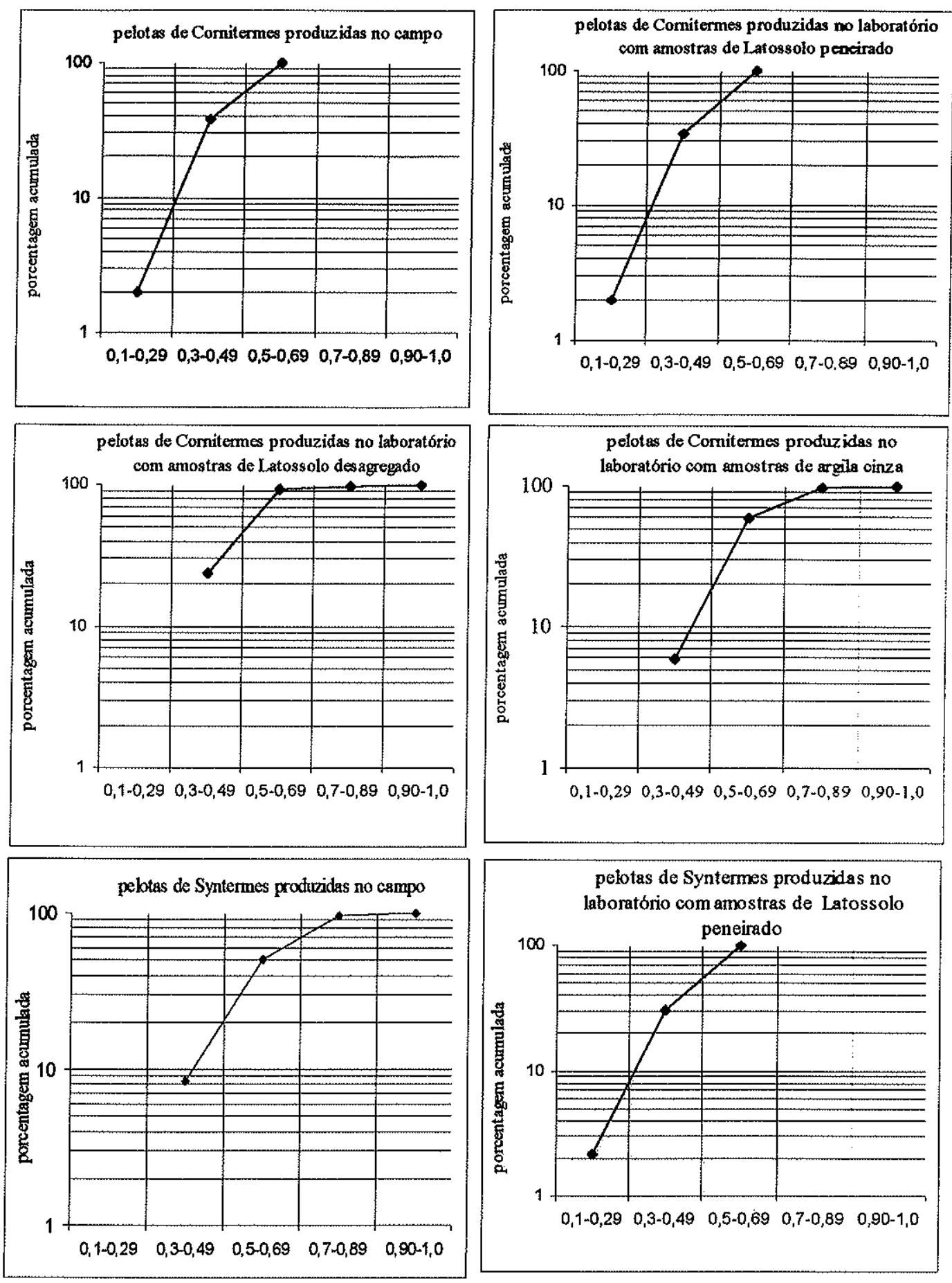

Figura 51: Curvas cumulativas da distribuição do arredondamento das pelotas dos cupins do laboratório e do campo. 

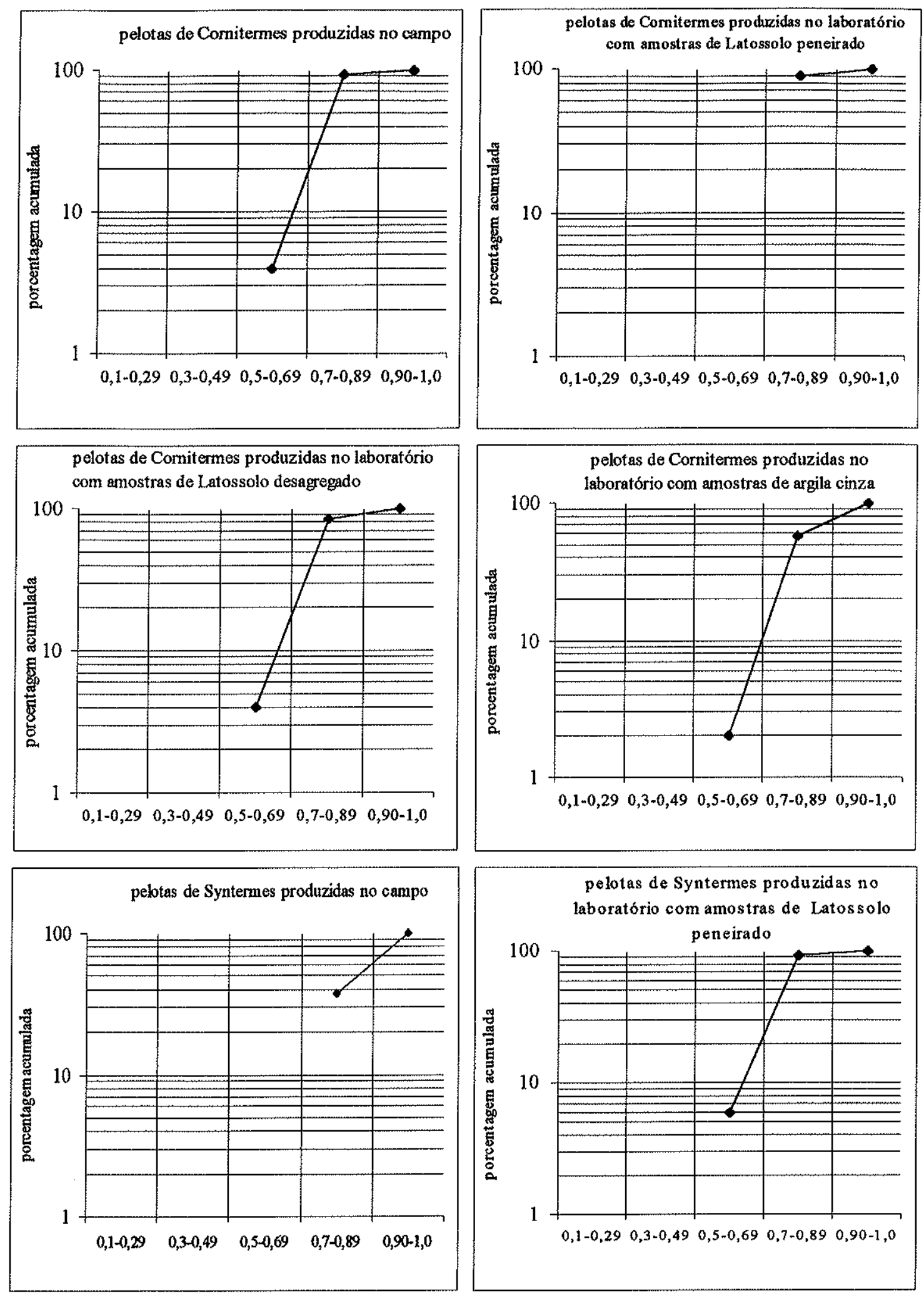

Figura 52: Curvas cumulativas da distribuição da esfericidade das pelotas dos cupins do laboratório e do campo. 


\subsection{Resistência à desagregação das pelotas}

Realizou-se ensaio de resistência à desagregação das pelotas produzidas pelos cupins seguindo metodologia (ítem 4.2.5) aplicada para os microagregados do Latossolo. Os resultados mostram que sob saturação sem imersão, as pelotas desagregam-se. Imersas em água ou em solução alcalina, as pelotas apresentam baixa estabilidade desagregando-se completamente. Os resultados das pelotas de cupins são muito semelhantes ao obtidos para os microagregados do Latossolo, porém, nas pelotas de cupins a hidratação e a desagregação são instantâneas, enquanto para os microagregados do Latossolo ocorreu frequentemente uma fragmentação angulosa prévia e depois uma desagregação acompanhada de uma separação do plasma e do esqueleto. Este fato está sendo interpretado como resultado de baixa compactação durante a produção das pelotas pelos cupins, que pode estar refletindo em parte, hábitos de estresse dos cupins, tanto no campo, como no laboratório, ou mesmo estar relacionado as pelotas naturalmente pouco compactadas, produzidas "na urgência" de reparo da superficie dos canais.

Tabela 9: Ensaios de resistência à desagregação das pelotas de cupins de campo e laboratório em diferentes condições hídricas.

\begin{tabular}{|c|c|c|c|c|}
\hline \multirow{2}{*}{ Pelotas } & \multicolumn{3}{|c|}{ Tratamento } & \multirow[b]{2}{*}{$\begin{array}{c}\text { Tipo de } \\
\text { desagregacăo* }\end{array}$} \\
\hline & $\begin{array}{l}\text { Saturação } \\
\text { por } \\
\text { capilaridade }\end{array}$ & $\begin{array}{l}\text { Imersä́o } \\
\text { em H2O }\end{array}$ & $\begin{array}{c}\text { Imersão } \\
\text { em } \\
\text { solução } \\
\text { NaOH } \\
0,1 N \\
\end{array}$ & \\
\hline $\begin{array}{l}\text { Pelotas de Cornitermes produzidas no } \\
\text { campo }\end{array}$ & $\mathrm{O}$ & XX & $\mathrm{XX}$ & $(1),(2)$ \\
\hline $\begin{array}{l}\text { Pelotas de Cornitermes produzidas no } \\
\text { laboratório com amostras de Latossolo } \\
\text { desagregado }\end{array}$ & $\mathrm{O}$ & $\mathrm{X}$ & $\mathrm{XX}$ & $(1),(2)$ \\
\hline $\begin{array}{l}\text { Pelotas de Cornitermes produzidas no } \\
\text { laboratório com amostras de Latossolo } \\
\text { peneirado }\end{array}$ & $\mathrm{X}$ & $\mathrm{X}$ & $\mathrm{XX}$ & $(1),(2)$ \\
\hline $\begin{array}{l}\text { Pelotas de Cornitermes produzidas no } \\
\text { laboratório com amostras de argila cinza }\end{array}$ & 0 & $\mathrm{X}$ & $\mathrm{XX}$ & $(1),(2)$ \\
\hline $\begin{array}{l}\text { Pelotas de Syntermes produzidas no } \\
\text { campo }\end{array}$ & $\mathrm{O}$ & $\mathrm{X}$ & $\mathrm{XX}$ & (1), (2) \\
\hline $\begin{array}{l}\text { Pelotas de Syntermes produzidas } \\
\text { no laboratório com amostras de } \\
\text { Latossolo peneirado }\end{array}$ & $\mathrm{O}$ & $\bar{X}$ & $\mathrm{XX}$ & $(1),(2)$ \\
\hline
\end{tabular}

Desagregação: (o) ausente $(\mathrm{x})$ presente $(\mathrm{xx})$ muito freqüente. Tipo de desagregação (1) dispersão plasma-esqueleto, (2) quebra angulosa. 
5.17 Distribuição do tamanho das pelotas (experimentação por granulometria a laser)

As pelotas das duas espécies de cupins e produzidas no campo apresentam uma distribuição específica, com diâmetro modal em torno de $20 \mu \mathrm{m}$. Para Syntermes, as pelotas estão distribuídas entre 2 e $70 \mu \mathrm{m}$ de diâmetro, enquanto para Cornitermes as pelotas estão distribuídas entre 2 e $200 \mu \mathrm{m}$ de diâmetro, adquiridos com granulômetro a laser e com microscópio (figura 53), diferem sensivelmente entre si, o que pode ser interpretado como decorrência da baixa estabilidade das pelotas em água. As pelotas desfazem-se durante a análise por granulometria a laser. Apesar das análises serem preliminares é possivel concluir que a distribuição granulométrica das pelotas é bem específica e bem distinta daquelas apresentadas na figura 33 para os microagregados do Latossolo. Análises complementares poderão trazer contribuição sobre o comportamento granulométrico específico das pelotas de diferentes espécies.

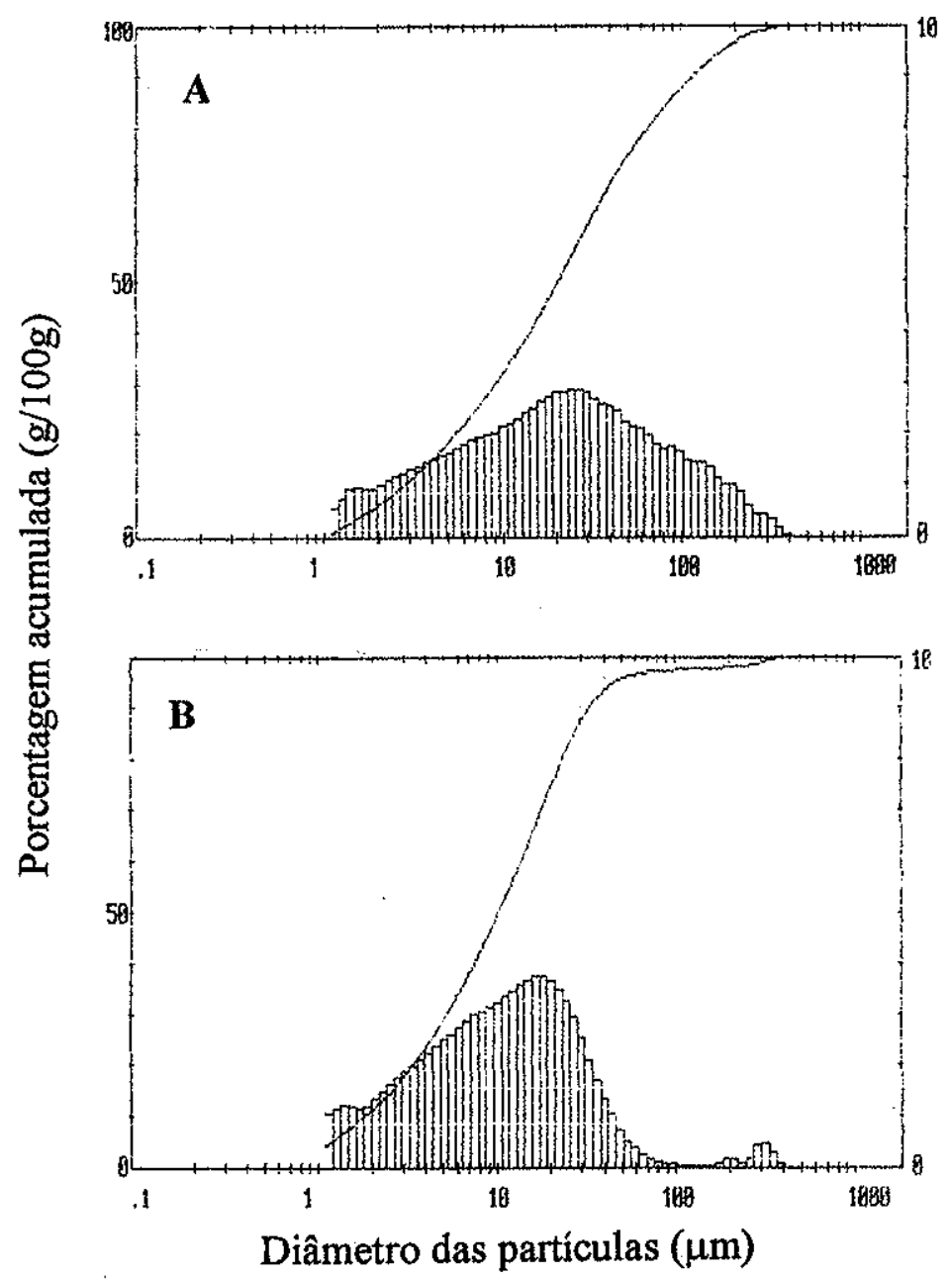

Figura 53: Distribuição do tamanho das pelotas produzidas no campo (A) Cornitermes (B) Syntermes por granulometria à laser. 


\subsection{Caracterização química das pelotas}

A análise química do solo utilizado no laboratório correspondeu aos resultados do Latossolo de Iracemápolis, na profundidade $100-120 \mathrm{~cm}$ (tabela 3) e o carbono e o nitrogênio das pelotas (figura 54) foram analisados nas pelotas produzidas por Cornitermes no laboratório com amostras de Latossolo desagregado (T1), Latossolo peneirado (T2). As pelotas produzidas com argila cinza foram analisadas na amostra antes da atividade dos cupins (T3), na amostra bruta ( sem separação de frações) e nas frações argila, silte e areia. Conclui-se que a relação $\mathrm{C} / \mathrm{N}$ das pelotas fabricadas no laboratório com as amostras do Latossolo, (desagregado e peneirado) é superior a relação $\mathrm{C} / \mathrm{N}$ da profundidade $0-35 \mathrm{~cm}$ do perfil do Latossolo do perfil. No caso da argila cinza, a amostra antes da atividade dos cupins e nas pelotas sem separação apresentou relação $\mathrm{C} / \mathrm{N}$ muito próxima, concentrando-se na fração argila da amostra.

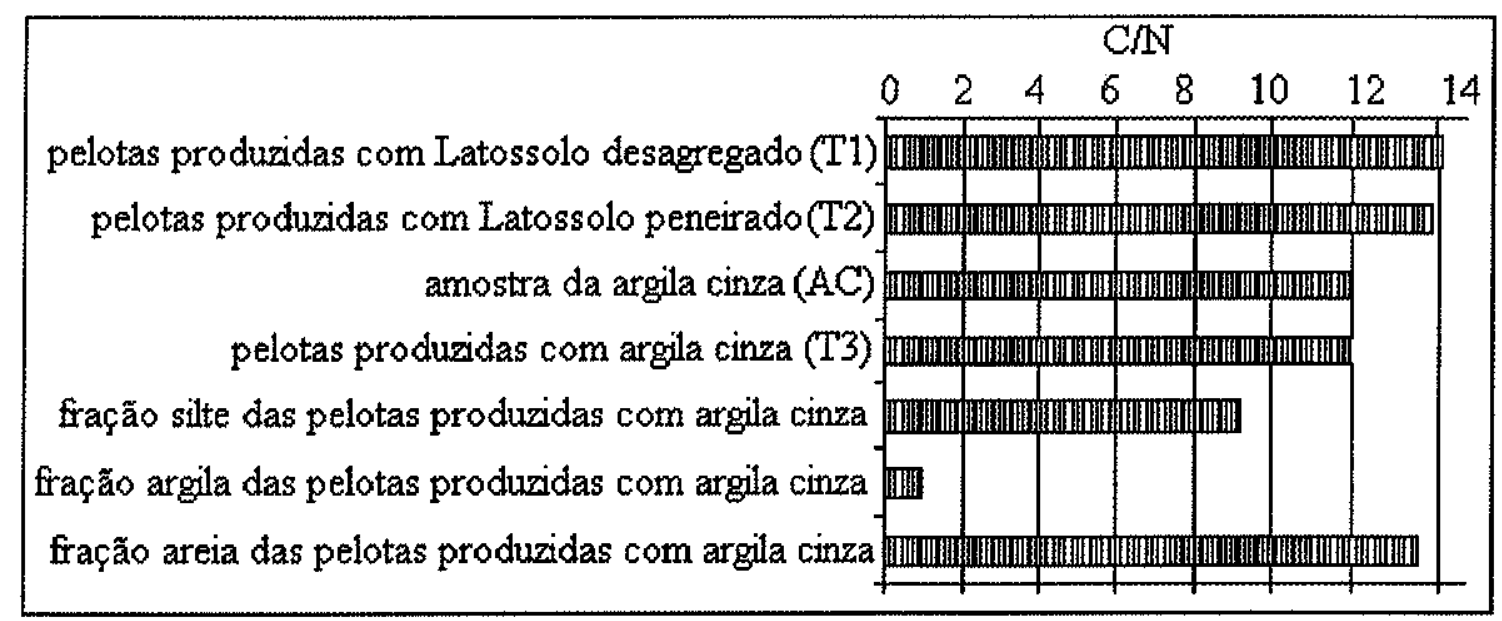

Figura 54: Razão $\mathrm{C} / \mathrm{N}$ para as pelotas de Cornitermes produzidas no laboratório.

\subsection{Caracterização mineralógica das pelotas}

Na figura 55 estão apresentados os difratogramas da fração argila extraída das pelotas produzidas por cupins (Cornitermes) no laboratório, utilizando amostras de Latossolo desagregado (amostra T1), de Latossolo peneirado (amostra T2) e de argila cinza. A fração argila extraída das pelotas não foi deferruginizada e na composição de ambas aparece caolinita, quartzo, gibbsita e hematita. 
Para as pelotas fabricadas com amostras de argila cinza foi caracterizada a composição da amostra antes da atividade dos cupins $\mathrm{e}$ sob as pelotas a composição mineralógica não apresentou variação antes e depois de ser submetida a atividade de cupins.
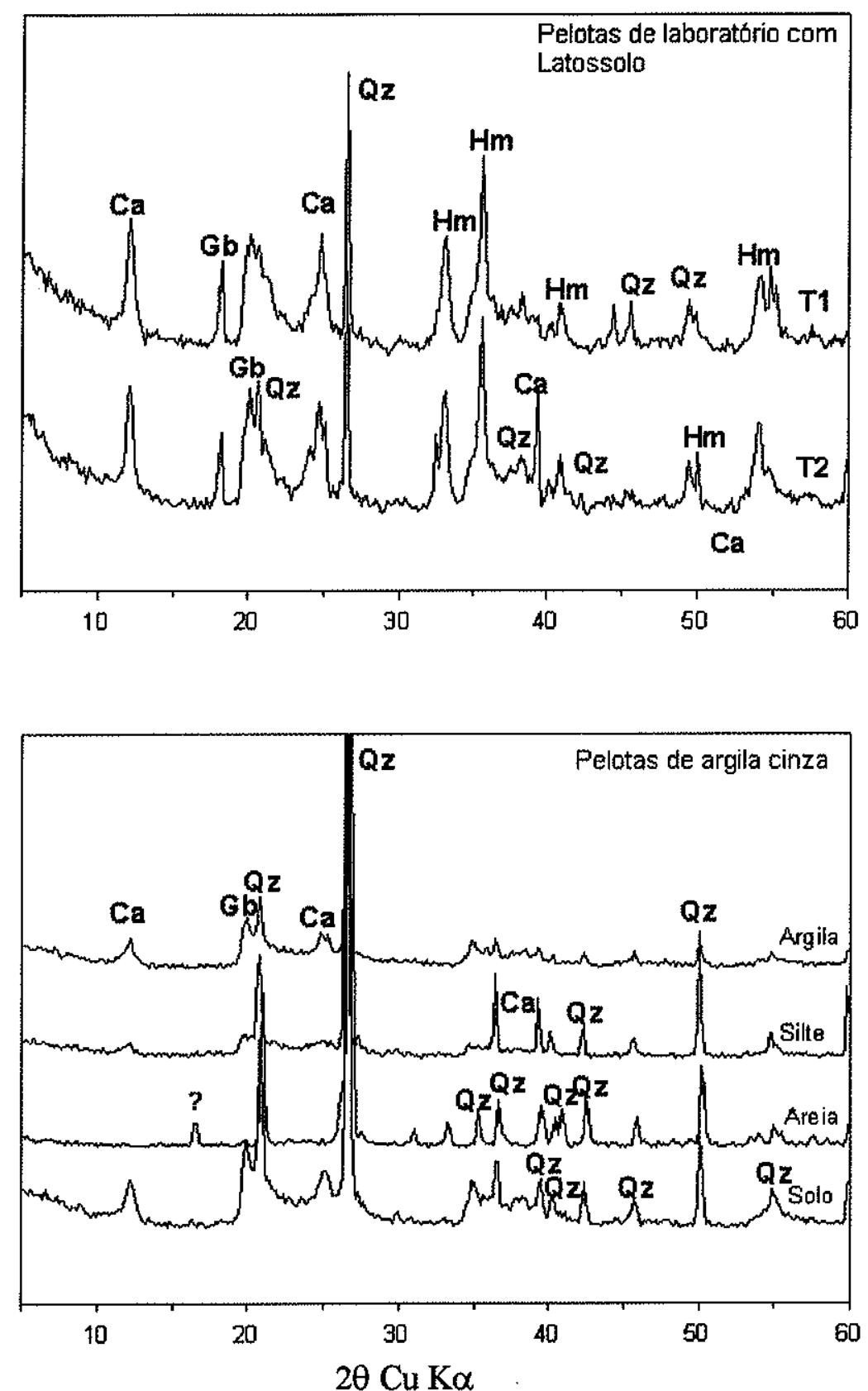

Figura 55: Difratogramas de raio $\mathrm{X}$ das pelotas de Cornitermes produzidas no laboratório com amostras de Latossolo, na fração total sem deferruginização. (T1) pelotas fabricadas com amostras de Latossolo desagregado (T2) ) pelotas fabricadas com amostras de Latossolo peneirado. $\mathrm{Ca}=$ caolinita; $\mathrm{Gb}=$ gibbsita; $\mathrm{Qz}=$ quartzo; $\mathrm{Hm}=$ hematita. 


\section{DISCUSSÃO FINAL}

Sobre o perfil e os microagregados do Latossolo de Iracemápolis

Do ponto de vista geoquímico, o Latossolo estudado apresenta-se em avançado estágio de pedogênese, enquadrando o desenvolvimento deste solo no domínio geoquímico da hidrólise parcial ou monossialitização (Melfi \& Pedro, 1978) que, atuando sobre as rochas básicas, promove a rápida alteração dos seus minerais.

$\mathrm{Na}$ área estudada, a cobertura vegetal de um bosque atua como refúgio da fauna, principalmente de formigas e cupins. A observação macroscópica em campo e análise em lupa das feições biológicas remanescentes, confirmaram a intensa pedoturbação biológica sobre o perfil, principalmente entre 0 a $120 \mathrm{~cm}$ de profundidade.

As observações micromorfológicas revelam a existência de um processo de desestruturação de microagregados a partir de fundo matricial denso porfírico e também a existência de coalescência de microagregados formando assembléia do tipo aglutínica, marcada por forte porosidade interconectada.

Em toda a extensão do perfil são encontrados microagregados, com maior desenvolvimento e homogeneidade entre 80 a $200 \mathrm{~cm}$ de profundidade.

Os microagregados analisados apresentam-se predominantemente na forma esferoidal, com razão morfométrica entre os eixos B/A e C/B entre 0,7 e 0,8 e contorno variando de subanguloso $(0,5)$ a subarredondado $(0,7)$.

$\mathrm{O}$ diâmetro predominante para todo o perfil foi entre 150 a $1000 \mu \mathrm{m}$, distribuído em diâmetro $>1 \mathrm{~mm}$ (média de $24 \%$ entre $0-35 \mathrm{~cm}$ ) e diâmetro $<0,053 \mathrm{~mm}$ (média de $11,5 \%$ entre 80 $200 \mathrm{~cm}$ ).

Quanto aos tipos morfológicos, encontra-se dois tipos principais de microagregados sendo um tipo composto (com subestrutura de diâmetro médio de $100 \mu \mathrm{m}$ ) que predomina na classe> $1 \mathrm{~mm}$, e um tipo maciço (sem subestrutura) que ocorre em todas as classes.

As análises em MEV permitem visualizar que a junção entre os microagregados menores que formam o tipo compostos é feita por plasma argiloso caolinítico.

As análises de estabilidade hídrica, demonstram que os microagregados do tipo com subestrutura é pouco estável quando saturado em água, desagregando-se nas subestruturas 
formadoras, enquanto o tipo maciço apresenta-se com boa estabilidade em água, mas ambos desagregam-se totalmente em solução alcalina.

\section{$\underline{\text { Sobre a pelotas dos cupins }}$}

As pelotas dos cupins produzidas em campo e no laboratório para dois gêneros de cupins apresentam-se predominantemente na forma esferoidal, com índice B/A e C/B entre 0,7 a 0,8, com arredondamento entre anguloso $(0,1)$ a bem arredondado $(0,9)$ dominando no entanto contorno subanguloso $(0,5)$ a subarredondado $(0,7)$.

$\mathrm{O}$ diâmetro das pelotas é específico para a espécie produtora, associado ao tamanho dos cupins, e observa-se uma similaridade ente o diâmetro das pelotas produzidas no campo e no laboratório. Para Cornitermes varia entre 800 a $1400 \mu \mathrm{m}$ (diâmetro máximo) e para Syntermes entre $2200 \mu \mathrm{m}$ (diâmetro máximo).

Semelhantemente aos microagregados do Latossolo, observa-se dois tipos de pelotas produzidas pelas duas espécies. O tipo composto com subestrutura, é produzido no campo e com amostras de solo peneirado (a $100 \mu \mathrm{m}$ ) no laboratório e o tipo maciço (sem subestrutura) é produzido no campo e no laboratório.com amostras de solos testada (solos desagregado e argila cinza).

A análise micromorfológica permite observar que, internamente, as pelotas apresentam arranjo porfírico, com triagem granulométrica aparente do esqueleto e formam arranjos coalescentes com forte porosidade interconectada.

Análises em MEV revelam diversas marcas ou impressões na superfície das pelotas que servem como impressões digitais da ação dos cupins. Estas marcas são visíveis nas pelotas produzidas em laboratório com amostras de solo muito argilosa (Latossolo desagregado e argila cinza, produzidos por Cornitermes). Nas pelotas de campo e na parede dos canais também observa-se estas marcas, porém em menor abundância.

Os ensaios de estabilidade mostram que as pelotas são pouco estáveis quando imersas em água, o que pode estar relacionado a pouca compactação destas durante sua produção pelos operários, o que pode estar ligado a aspectos comportamentais de estresse no campo e principalmente no laboratório. Um aspecto a ser considerado é que, naturalmente em uma colônia, diferentes tipos de pelotas são produzidas para usos específico na construção e de acordo com a disponibilidade de materiais para construção (Noirot, 1970; Eschenbrenner, 1986). 
Sobre a metodologia utilizada $O$ peneiramento a seco permitiu avaliar a distribuição de diferentes classes de microagregados presentes no solo.

As análises químicas e mineralógicas de caraterização efetuadas no perfil do solo (peneirado a $2 \mathrm{~mm}$ ), representa indiretamente a composição dos microagregados.

Os resultados de $\mathrm{C} / \mathrm{N}$ e da mineralogia para os microagregados do solo e as pelotas apresentam-se similares.

As análises por granulometria a laser indica tamanhos específicos para os microagregados do Latossolo e as pelotas, podendo ser uma interessante ferramenta para a diferenciação entre estes materiais nos solos.

As análises em microscopia de varredura da superficie das pelotas indica que a presença de marcas impressas na superficie das pelotas e na parede dos canais podem auxiliam de forma específica na determinação de microagregados produzidos por cupins

As análises de estabilidade em água indica a existência de características fisicas entre os microagregados do solo e pelotas dos cupins.

Os trabalhos com os cupins no laboratório possibilitaram observar diferentes aspectos da atividade dos cupins de diferentes espécies e tipos de solo. 


\section{CONCLUSÕES}

É dificil mensurar a contribuição efetiva dos cupins na formação de microagregados. No entanto, o estudo realizado permite afirmar que a fauna, de cupins e formigas principalmente, contribui significativamente para a pedoturbação e homogenização do Latossolo de Iracemápolis pelo menos até a profundidade de $120 \mathrm{~cm}$.

Microagregados dos tipos composto (com subestrutura) e maciço (sem subestrutura) são encontrados tanto no Latossolo como produzidos pelos cupins no campo e no laboratório, apresentando fortes semelhanças morfológica, de dimensão e do arranjo interno.

Uma gênese complexa é o melhor termo para definir a microagregação do Latossolo, uma vez que os microagregados descritos refletem diferentes processos de agregação e desagregação de partículas, associados a processos biológicos, geoquímicos e estruturais.

A ocorrência de desestruturação do fundo porfírico denso entre 0 e $120 \mathrm{~cm}$, com formação de microagregados, é um importante mecanismo de arranjo estrutural do solo e os fatores que provocam estas transformações são complexos, podendo ser de natureza pedoclimática subatual (Miklos, 1992) ou mesmo resultados de práticas agrícolas mecanizadas (Curmi et al., 1994).

Ao contrário da desestruturação dos microagregados, porções com microagregados coalescentes com forte porosidade interconectada, encontradas no Latossolo, refletem processos de adensamento de material microagregado, resultando em um ciclo de desestruturaçãoadensamento de microagregados.

Os ensaios realizados no laboratório (atividade de produção de pelotas em terrário) forneceram informações importantes para a compreensão da gênese das pelotas. A atividade construtora dos cupins, imprimem marcas na superfície das pelotas que podem servir como impressão digital na diferenciação entre pelotas e microagregados.

Além da participação efetiva na fabricação de microagregados, na escala da paisagem, é notável a contribuição dos cupins para a própria evolução destes "solos de superficie antigas". O remonte remonte vertical ascendente de matéria mineral (argila) intensifica os processos pedogenéticos de adição vertical e homogenização.

A atividade dos cupins ao longo do tempo geológico, pode resultar em modificações na escala continental, sob condições geológicas e climáticas favoráveis. No entanto, os processos geoquímicos e estruturais atuam de maneira importante na formação de microagregados no Latossolo. 


\section{REFERÊNCIAS BIBLIOGRÁFICAS}

ARAÚJO, R.L. Termites of the Neotropical Region. p. 527-576. In: Krishina, K; Weesner, F. M. Biology of termites. vol. 1, Academic Press, N.Y., London., 1970.

BEAUdoU, A .G., CHATEliN,Y.; COLlinet, J.; MARTIN, D. SALA, G..H. Notes sur la micromorphologie de certains sols ferralitiques jaunes de régions équatoriales d'Afrique. Cahier ORSTOM, Série Pedologie. v.XV, no. 4, p.361-379, 1977.

BRANNER, J.C. Geologia Elementar. $2^{\text {a }}$ edição. Rio de Janeiro. Livraria Francisco Alves Editora S.A. 1915. 396p.

BREWER, R. Fabric Mineral Analysis of Soils. Wiley and Sons, Inc. New York .470p. 1964.

BRINDLEY, G.W; BROWN, G. Crystal Structures of clay minerals and their x-ray identification. London, Mineralogical Society. 495p. 1984.

BUOL, S. W. HOLE, F.D; McCRACKEN, R.J; SOUTHARD, R.J. Soil Genesis and Classification. Iowa State University Press. USA, $4^{\text {Th }}$ Edition. 1997. 527p.

BULLOCK, P.; FEDEROF, N.; JONGERIUS, A.; STOOPS, G.; TURSINA, T. Handbook for soil thin section description. London: Waine Research Publications, 1978. 152p.

CAMARGO, M.N; KLANT, E. KAUFFMAN, J.H. Sistema Brasileiro de Classificação de Solos. Boletim Informativo da Sociedade Brasileira de Ciências do Solo, no. 12, p.11-13.1987.

CANCELLO, E.M. Rhynchotermes guarany, new species and Rhynchotermes piauy, new species (Isoptera, Termitidae, Nasutermitinae) from Brazil. Papéis avulsos de Zoologia. no.40, vol. 9 , p147-15, 1997.

CHAPELL, A. Dispersing sandy soil for the measurement of particle size distribuitions using optical laser diffraction. Catena, vol.31, p.271-281, 1998.

CHAUVEL, A. \& PEDRO, G. Genese de sols beiges ferrugineux tropicaux lessivés par transformation de sols rouges (ferralitiques) de Casamance (Senégal). Modalités de leur propagation. Cahier ORSTOM, Série Pedologie. v. XVI, no.3, p.231-249, 1978. 
CHAUVEL, A.; BOCQUIER, G.; PEDRO, G. La stabilité et la transformation de la microestrucuture des sols rouges ferralitiques de Casamance (Sénégal). In: Proceedings of $\mathrm{V}^{\text {th }}$ international Working Meeting on soil micromorphology, Granada, Ed. M. Delgado,, vol. II, p779-813, 1978

CLOUD. P, GUSTAFSON, L.B, WATSON, J.A. The works on living social insects as pseudofossils and the age of the oldest known metazoa. Science, v. 210, no. 28, p. 1013-1015. Nov. 1980.

COMISSÃO NACIONAL DE SOLOS. Levantamento de reconhecimento de solos do Estado de São Paulo. Rio de janeiro, Ministério da Agricultura. Boletim do Serviço Nacional de Pesquisas Agronômicas. Boletim Técnico no.12, 1960, 634p.

CONSTANTINO, R. Chave ilustrada para identificação dos gêneros de cupins (Insecta: Isoptera) que ocorrem no Brasil. Papéis avulsos de zoologia. no.40, v. 25, p.387-448, 1999.

CURMI, P; KERTZMAN, F.F; NETO, J.P. Degradation of structure and hydraulic properties in an Oxisol under cultivation (Brazil). In: PROCEEDINGS OF THE $X$ INTERNATIONAL WORKING MEETING ON SOIL MICROMORPHOLOGY. Abstracts. Australia v.I, p.569$579,1994$.

EDWARDS, A.P.; BREMNER, J.M. Microaggregates in soils. Journal of Soil Science, v. 18, p.6473. 1967.

ELLIOT, J.; PANSTRANK, S. Aggregate and soil organic matter dynamics under conventional and no-tillage systems. Soil Science American Journal, v.63, no. 5, p. 1350-1358, 1999.

EMERSON, W. W; Foster, R. C.; Oades, J. M. Organo mineral complexes in relation to soil aggregation and structure. In: Interactions of soil minerals with natural organics and microbes. Soil Science Society American Special Publication, no. 17, p.521-546. 1986.

ESCHENBRENNER, V. Contribution des termites à la micro-agrégation des sols tropicaux. Cahier ORSTOM, Série Pedologie. v.22, no. 4. p.397-408, 1986

ESCHENBRENNER, V. Les glébules des sols de Cotê D'Tvoire. Nature et origine en milieu ferralitique. Modalités de leur concentration. Rolê des termites. Collection Travaux et Documents microédités. Edition de L'ORSTOM. Paris. Tome 2. 281 p.1988. 
ESCHENBRENNER, V. Termite Activity and Soil Morphology in Tropical Areas. (compact disk). In: CONGRESSO LATINO-AMERICANO DE CIÊNCIA DO SOLO, 13., Águas de Lindóia. 1996. Solo-suelo, 96. trabalhos. Piracicaba: SBCS/SLCS.

ESWARAN, H; ; BUOL, S. W. The micromorphology of Oxisols. In: PROCEEDINGS OF THE IX INTERNATIONAL WORKING MEETING ON SOIL MICROMORPHOLOGY. Abstracts. Granada, M. Delgado ed., v. I, p. 325-347, 1978.

FAO/UNESCO.1971, Soil map of the world. 1:5000000. v. IV: South America. UNESCO, Paris.

GONÇALVES, N.M.M. Transformações mineralógicas e estruturais relacionadas a alteração hidrotermal e intempérica de rochas vulcânicas básicas da Bacia do Paraná Setentrional (Região de Ribeirão Preto - SP, Brasil). São Paulo, 1987. v. 1, II. 212p. Tese de Doutoramento, Instituto de Geociências, Universidade de São Paulo.

GOUDIE, L. R. The Geomorfological role of termites and earthworms in the tropics. In: VILES, H. A. Biogeomorphology. Oxford, New York. Basil Blackwell. Ltd. 1988. 365p.

GRASSÉ, P.P. Termitologia. Anatomie, physiologie, biologie systématique des termites. Tome 2: Fondation des Sociétés-Constructions. Fondation Singer-Polignac, Masson, 676p. 1984.

GRAMINHA, C. A. \& MELFI, A..J. Atividade construtora de cupins de solo (Nasutitermitinae: Cornitermes sp. e Syntermes sp.) em condições de laboratório. In: REUNIÃO ANUAL DA SOCIEDADE BRASILEIRA PARA O PROGRESSO DA CIÊNCIA. $52^{\circ}$, Resumos. Brasilia, DF. Julho 2000. p.99.

HEDLUND, J.C.; HENDERSON, G. Effect of available food size on search tunnel formation by the formosan subterranea termite (Isoptera: Rhinotermitidae). Journal of Economic Entomology, v.92, no. 3, p.610-615, 1999 .

IPT- INSTITUTO DE PESQUISAS TECNOLÓGICAS DO ESTADO DE SÃO PAULO. Mapa geomorfológico do estado de São Paulo. Escala 1:500.000,São Paulo, v. I (texto explicativo), Divisão de Minas e Geologia Aplicada, 1981, 126p.

JORDAN, C.F. The tropical rainforest lanscape. In: VILES, H. A. Biogeomorphology. Oxford, New York. Basil Blackwell. Ltd. 1988. 365p. 
JUNGERIUS, P.D.; VAN DEN ANCKER, J.A.M.; MÜCHER, H.J. The contribution of termites to the microgranular structure of soils on the Uasin Gishu Plateau, Kenya. Catena, no. 34, p.349$363,1999$.

KIEHL, E.J. Manual de edafologia; relações solo-planta. São Paulo: Ceres. 1979.

LADEIRA, F.S.B. Estudo micromorfológico de um Latossolo Roxo no munícípio de Guaíra. São Paulo,1995. 143p. Dissertação de mestrado. Departamento de Geografia. Faculdade de Filosofia, Letras e Ciências Humanas da Universidade de São Paulo.

LAVELLE, P. Faunal activies and soil processes: adaptative strategies that determine ecosystem function. In: PROCEEDINGS OF THE $15^{\mathrm{TH}}$ WORLD CONGRESS OF SOIL SCIENCE. Abstracts. Acapulco, Mexico, v. I, p.189-220,1994.

LEE, K.E; WOOD, T, G. Termite and soils. London, New York: Academic Press, 1971. 251p.

LEMOS, R. C.; SANTOS, R. D. Manual de descrição e coleta de solo no campo. Soc. Bras. Ciências do solo, $3^{\mathrm{a}}$. edição, Campinas, $1996.84 \mathrm{p}$.

LENKO, K.; PAPAVERO, N. Insetos no folclore. São Paulo, $2^{a}$ edição. Editora Plêiade/ FAPESP. $1996,468 \mathrm{p}$.

LEVY, G.J.; AGASSI, M.; SMITH, H.J.C.; STERN, R. Microaggregate stability of caolinitic and illitic soils determined by ultrasonic energy. Soil Science Society of America Journal. V.57, no. 3, p. 803-808, 1993.

MACHADO, A. de B. The contribuition of termites to the formation of laterites. In: PROCEEDINS OF $2^{\text {nd }}$ INTERNATIONAL SEMINAR ON LATERITISATION PROCESSES. Melfi, A.J; Carvalho, A. São Paulo, EDUSP, p. 261-270, 1983.

MAETERLINK, M. A vida das formigas. Ed. Hemus. São Paulo.117p.

MARTINEZ-DELCLOS, X. ; MARTINELL, J. The oldest known record of social insects. Journal Paleontology, v.69, no. 3, p.594-599, 1995. 
MELFI, A. J. Intemperismo de granitos e diabásios no município de Campinas e arredores, Estado de São Paulo. Tese de Doutoramento, Faculdade de Filosofia Ciências e Letras da Universidade de São Paulo. v.1, 1967.

MELFI, A, J.; PEDRO, G. Considerações sobre os mecanismos geoquímicos envolvidos na alteração superficial e sua repartição no Brasil. Revista Brasileira de Geociências, v.8, p.11$22,1978$.

MERMUT, A. R.; ASHAD, M.A.; ARNAUD, R. J. ST. Micropedological study of termite mounds of three species of Macrotermes in Kenya. Soil Science American Journal, v.48, p. 613620.1984 .

MIKLOS, A. A.de W. Biodynamique d'une coverture pédologique dans la région de Botucatu, Brésil. Paris, France, 1992, 247p. v. I et II. Thèse de doctorat, Université Paris VI.

MIKLOS, A. A.de W. Contribuição da fauna do solo na gênese de Latossolos e "Stone Lines" (compact disk). In: CONGRESSO LATINO-AMERICANO DE CIÊNCIA DO SOLO, 13., Águas de Lindóia.1996. Solo-suelo,96. trabalhos. Piracicaba: SBCS/SLCS, 1996.

MONREAL, C.M; KODAMA, H. Influence of aggregate architecture and minerals on living habitats and soil organic matter. Canadian Journal of Soil Science,n.77, p.367-377. 1997.

MONREAL, C.M; SCHNITZER, M.; SCHULTEN, H. R.; CAMPBELL, C. A.; ANDERSON, D.W. Soil organic structures in macro and microaggregates of a cultivated brown Chernozem. Soil Biology and Biochemistry, v.27, no. 6, p.845-853, 1995.

MUGGLER, C.C.; PAPE, Th.; BUURMAN, P. Laser grain-size distribuition in soil genetic studies2. Clay content, clay formation, and aggregation in some brazilian Oxisols. Soil Science, vol. 162, no. 3, p. 219-228. March, 1997

MULLER, G. Methods in sedimentary petrography (part I). New York, Hafner Publishing Co., 283 p. , 1967.

MULLER, J.P. Microstructuration des structichrons rouges ferralitiques à l'amont des modeles convexes (Centre-Cameroun). Aspects morphologiques. Cahier ORSTOM, Série Pedologie. v. 15, p. 239-258, 1977. 
NASCIMENTO, H.E.M., DIAS, A da S., TABANEZ, A.A.J. e VIANA, V.M. Estrutura e dinâmica de populações arbóreas de um fragmento de floresta estacional semidecidual na região de Piracicaba, SP. Revista Brasileira de Biologia. v.59, no. 2, p.329-342, 1999.

NIMER, E. Climatologia do Brasil. Rio de Janeiro. Série Recursos Naturais e Meio Ambiente, Inst. Bras. Geogr. Estatística, IBGE, 1979, 422p.

NOIROT, Ch. The nests of termites. In: KRISHNA, K; WEESNER F.M. Termite Biology. New York, London: Ed. Academic Press, 1970, v.2, p.73-125.

OLIVEIRA, J.B. de; MENK, J. R. F. Latossolos Roxos do estado de São Paulo. Campinas, Boletim Técnico do Instituto Agronômico, no .82, 1984, 132p.

PEDRO, G.; CHAUVEL, A. ; MELFI, A. J. Recherches sur la constituition des Terra Roxa Estructurada du Brésil. Ann. Agron., 27, no 3, p. 265-294, 1976.

PESSENDA, L. C. R; VAlencia, E. P. E.; CAMARGo, P. B.; Telles, E. C. C.; MARTINELLI, L. A; CERRI, C. C.; RAMON, A.; ROZANSKI, K. Natural radiocarbon measurements in brazilian soils developed on basic rocks. Radiocarbon, v.38, no. 2, p. 203$208,1996$.

SINGH, S.; SING, J. S Microbial biomass associated with water stable aggregates in forest, savanna and cropland soils of seasonally dry tropical region, India. Soil Biology and Biochemistry, v.27, no .8, p. 1027-1033, 1995.

SOARES, M. T. S. Solos e bioconstruções: morfologia e geoquímica dos cupinzeiros e dos solos associados na região de Humaitá (sul do estado do Amazonas) Piracicaba, São Paulo, 1999. vol. I. 129p. Dissertação de Mestrado, Escola Superior de Agronomia Luiz de Queiroz, Universidade de São Paulo.

STOOPS, G.; BUOL, S. W. Micromorphology of Oxisol. In: DOUGLAS, L.A \& THOMPSON, M. L. eds. Soil micromorphology and soil classification. Madison, Soil Science Society of America, 1985. P. 105-119.

SUGUIO, K. Introdução à Sedimentologia. São Paulo, Ed. Edgard Blücher/EDUSP, 1973, 317p. 
TATE, K.R.; THENG, B.K.G. Organic matter and its interactions with inorganic soil constituints. Academic Press Ed. London, 225-249p. 1977.

TISDALL, J.M.; OADES, J. M. Organic matter and water-stable aggregates in soils. Journal of Soil Science, n.33, p.141-163, 1982.

TOMÉ JÚNIOR, J.B. Manual para interpretação de análise de solo. Guaíba, RS. Brasil: Agropecuária Ed.,1997, 247p.

TRAPNELL, C. G.; WEBSTER, R. Microaggregates in red earths and related soils in East and Central Africa, their classification and occurrence. Journal of Soil Science, n.37, p.109-123, 1986.

USDA. Soil Taxonomy. Agriculture handbook n. 436. Soil Conservation Service. Governm. USA. Washington, D.C. Printing Office, 1975.

VIDAL-TORRADO, P.; LEPSCH, I. F.; CASTRO, S. S. de; COOPER, M. Pedogenesis of an Oxisol-Ultisol-Alfisol sequence on the border of a plateau at the Paulista Peripherical Depression in Brazil. Revista Brasileira de Ciência do Solo, no. 23, p.909-921,1999.

WILLIANS, E. M. A method of indicating pebble shape property of sand grains. JOURNAL OF Sedimentary Petrology, 41 (3): 703-714. 1965.

ZINGG, T, H. Beitrag zur Schotteranalyse. Schweiz Mineralog. Petrog. Mitt, Petrol. Geol. Bull, v. 30, p. $477-513,1935$. 